Prepared for the U.S. Department of Energy

under Contract DE-AC05-76RL01830

\title{
The 300 Area Integrated Field Research Challenge Quality Assurance Project Plan
}

NJ Fix

April 2009

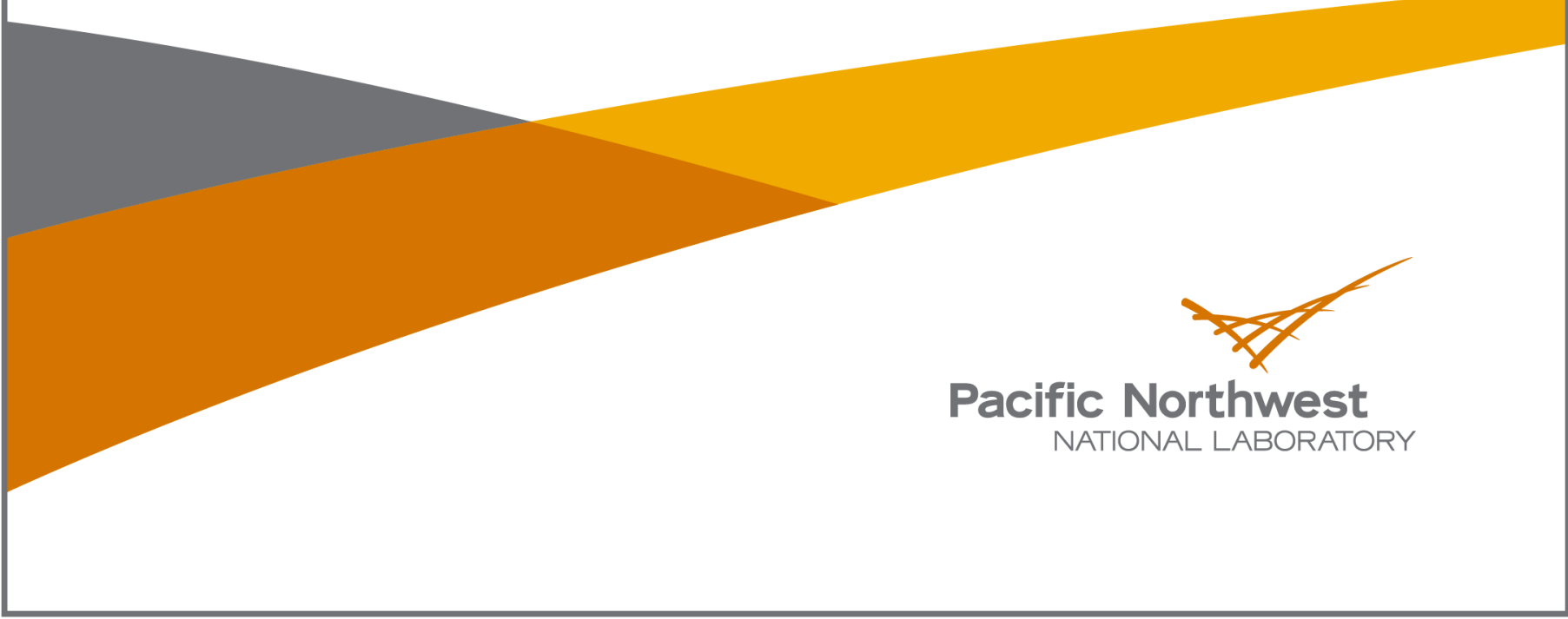




\title{
DISCLAIMER
}

This report was prepared as an account of work sponsored by an agency of the United States Government. Neither the United States Government nor any agency thereof, nor Battelle Memorial Institute, nor any of their employees, makes any warranty, express or implied, or assumes any legal liability or responsibility for the accuracy, completeness, or usefulness of any information, apparatus, product, or process disclosed, or represents that its use would not infringe privately owned rights. Reference herein to any specific commercial product, process, or service by trade name, trademark, manufacturer, or otherwise does not necessarily constitute or imply its endorsement, recommendation, or favoring by the United States Government or any agency thereof, or Battelle Memorial Institute. The views and opinions of authors expressed herein do not necessarily state or reflect those of the United States Government or any agency thereof.

\author{
PACIFIC NORTHWEST NATIONAL LABORATORY \\ operated by \\ BATTELLE \\ for the \\ UNITED STATES DEPARTMENT OF ENERGY \\ under Contract DE-AC05-76RL01830
}

Printed in the United States of America
Available to DOE and DOE contractors from the
Office of Scientific and Technical Information,
P.O. Box 62, Oak Ridge, TN 37831-0062;
ph: (865) 576-8401
fax: $(865) 576-5728$
email: reports@adonis.osti.gov

\author{
Available to the public from the National Technical Information Service, \\ U.S. Department of Commerce, 5285 Port Royal Rd., Springfield, VA 22161 \\ ph: (800) 553-6847 \\ fax: $(703) 605-6900$ \\ email: orders@ntis.fedworld.gov \\ online ordering: http://www.ntis.gov/ordering.htm
}

This document was printed on recycled paper. 


\section{The $\mathbf{3 0 0}$ Area Integrated Field Research Challenge Quality Assurance Project Plan}

NJ Fix

April 2009

Prepared for

the U.S. Department of Energy

under Contract DE-AC05-76RL01830

Pacific Northwest National Laboratory

Richland, Washington 99352 



\section{The 300 Area Integrated Field Research Challenge Quality Assurance Project Plan}

Project \# 51805

Prepared by

Pacific Northwest National Laboratory

Richland, Washington 99352

Issue Date: April 2009

\section{Approval:}

FB Metting, Product Line Manager

Fundamental and Computational Sciences

JM Zachara, Project Manager

Chemical \& Materials Sciences Division

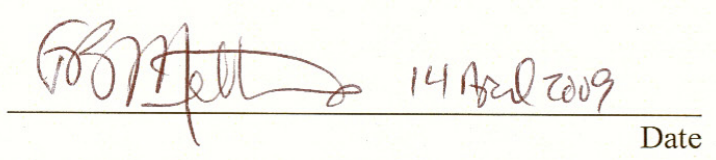

MD Freshley, Field Site Manager

Environmental Sustainability Division

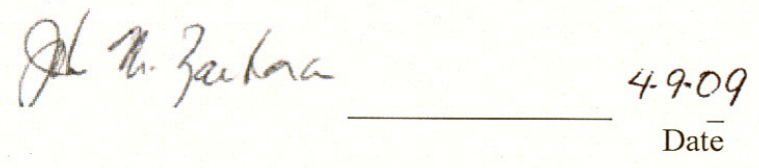

Concurrence:

NJ Fix, Project Quality Engineer

Quality Assurance Services
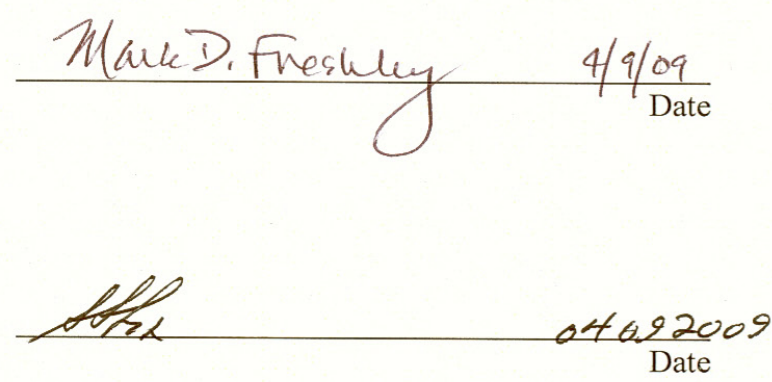



\begin{tabular}{|l|l|c|c|c|}
\hline \multicolumn{5}{|c|}{ Quality Assurance Project Plan Revision History } \\
\hline \multicolumn{4}{|c|}{ Formal revisions to this Quality Assurance Project Plan (QAPjP) are listed below. } \\
\hline Rev. \# & \multicolumn{1}{|c|}{ Comments } & $\begin{array}{c}\text { Effective } \\
\text { Date }\end{array}$ & Approvals \\
\hline 0 & Initial QAPjP release. & N/A & $1 / 8 / 08$ & \\
\hline 1 & $\begin{array}{l}\text { Annual review. Revised to address } \\
\text { changes in SBMS subject areas, } \\
\text { addition of geophysical analyses, } \\
\text { general editorial/consistency } \\
\text { corrections. }\end{array}$ & $03 / 09$ & $03 / 09$ & \\
\hline
\end{tabular}





\section{Summary}

Pacific Northwest National Laboratory and a group of expert collaborators are using the U.S. Department of Energy (DOE) Hanford Site 300 Area uranium (U) plume within the footprint of the 300-FF-5 groundwater operable unit as a site for an Integrated Field-Scale Subsurface Research Challenge (IFRC). The IFRC is entitled Multi-Scale Mass Transfer Processes Controlling Natural Attenuation and Engineered Remediation: An IFRC Focused on the Hanford Site 300 Area Uranium Plume Project (hereafter referred to as the 300 Area IFRC Project). The theme is investigation of multiscale mass transfer processes. A series of forefront science questions on mass transfer are posed for research that relate to the effect of spatial heterogeneities; the importance of scale; coupled interactions between biogeochemical, hydrologic, and mass-transfer processes; and measurements/approaches needed to characterize and model a mass transfer-dominated system.

Three site-specific hypotheses are being evaluated that take advantage of the unique hydrogeologic attributes of the site. The hypotheses focus on multi-scale mass transfer processes in the vadose zone and saturated zone, their influence on field-scale U(VI) biogeochemistry and transport, and their implications to natural attenuation and remediation. An innovative site has been designed that represents a transect from waste sources in the vadose zone, through contaminated aquifer regions, to final discharge to the Columbia River at the groundwater and Columbia River interface. Scientific and experimental collaborations, as well as leveraged facilities use and sharing, are planned with a DOE Office of Environmental Management (EM-22) project to evaluate the feasibility of polyphosphate-induced autunite precipitation to mitigate U(VI) discharge to the Columbia River. The 300 Area IFRC Project will proactively publish results in high-impact scientific journals; support collaborations with external DOE Environmental Remediation Sciences Division investigators; and transfer data, knowledge, and coupled models to the Hanford Site during and after the term of the project.

This Quality Assurance Project Plan (QAPjP) provides the quality assurance requirements and processes that will be followed by the 300 Area IFRC Project. The plan is designed to be used exclusively by project staff. To assist project staff, the QAPjP contains hyperlinks to appropriate sections of PNNL internal procedures that implement quality affecting criteria and regulatory requirements. The PNNL internal procedures are not accessible to non-PNNL staff and are not publicly available.

Although the project is being performed for the DOE Office of Science and is basic research, the results may be of interest to the Hanford Site community (DOE Environmental Management, Richland Operations, the Environmental Protection Agency, and the Washington State Department of Ecology) Therefore, the QAPjP is based on the requirements in the Environmental Protection Agency (EPA) Requirements for Quality Assurance Project Plans (EPA/240/B-01/003 ${ }^{1}$ ) in accordance with the Hanford Federal Facility Agreement and Consent Order (Tri-Party Agreement [Ecology et al. 1989²]); DOE Order 414.1C, "Quality Assurance",; and 10 Code of Federal Regulations 830, Subpart A, "Quality Assurance Requirements". ${ }^{4}$ The Price-Anderson Amendments Act ${ }^{5}$ also applies to this project.

\footnotetext{
${ }^{1}$ EPA/240/B-01/003. 2001. EPA Requirements for Quality Assurance Project Plans (QA/R-5). U.S. Environmental Protection Agency, Washington, D.C.

${ }^{2}$ Ecology - Washington State Department of Ecology, U.S. Environmental Protection Agency, and U.S. Department of Energy. 1989, as amended. Hanford Federal Facility Agreement and Consent Order. Document No. 89-10, Olympia, Washington.

${ }^{3}$ DOE Order 414.1C. 2005. Quality Assurance. U.S. Department of Energy, Washington, D.C.

${ }^{4} 10$ CFR 830, Subpart A, "Quality Assurance Requirements.” U.S. Code of Federal Regulations.

${ }^{5}$ Price-Anderson Amendments Act. Energy Policy Act of 2005. Title VI-Nuclear Matters, Subtitle A-PriceAnderson Act Amendments, Section 601 et. seq. Public Law 109-58, as amended. 42 USC 15801 et seq. 



\section{Acronyms and Abbreviations}

\begin{tabular}{|c|c|}
\hline ATS & Assessment Tracking System \\
\hline CAWSRP & Conducting Analytical Work in Support of Regulatory Programs \\
\hline CERCLA & Comprehensive Environmental Response, Compensation, and Liability Act \\
\hline CFR & Code of Federal Regulations \\
\hline CHPRC & CH2M Hill Plateau Remediation Company, LLC \\
\hline CMP & Configuration Management Plan \\
\hline DOE & U.S. Department of Energy \\
\hline DQO & Data Quality Objectives \\
\hline EM & DOE Office of Environmental Management \\
\hline EPA & U.S. Environmental Protection Agency \\
\hline ERSP & Environmental Remediation Science Program \\
\hline ERT & electrical resistivity tomography \\
\hline FREC & Field Research Executive Committee \\
\hline FY & fiscal year \\
\hline GB & gigabytes \\
\hline HASQARD & Hanford Analytical Services Quality Assurance Requirements Documents \\
\hline $\mathrm{ICN}$ & Interim Change Notice \\
\hline IFRC & Integrated Field-Scale Subsurface Research Challenge \\
\hline INL & Idaho National Laboratory \\
\hline LOI & letter of instruction \\
\hline LRB & laboratory record book \\
\hline M\&TE & measuring and test equipment \\
\hline MDL & method detection limit \\
\hline NRC & U.S. Nuclear Regulatory Commission \\
\hline OBER & DOE Office of Biological and Environmental Research \\
\hline OJT & on-the-job-training \\
\hline PAAA & Price-Anderson Amendments Act \\
\hline PDF & portable document format \\
\hline PI & Principal Investigator \\
\hline PMP & Project Management Plan \\
\hline PNNL & Pacific Northwest National Laboratory \\
\hline QA & quality assurance \\
\hline QAP & Quality Assurance Plan \\
\hline QAPjP & Quality Assurance Project Plan \\
\hline RCRA & Resource Conservation and Recovery Act \\
\hline SBMS & Standards-Based Management System \\
\hline
\end{tabular}


$\mathrm{SC}$

SOW

SPP

SRS

STOMP

TRIM

V\&VPR

VPP

VVR

WBR
DOE Office of Science

statement of work

south process pond

Software Requirements Specification

Subsurface Transport Over Multiple Phases

Total Records Information Management

Verification and Validation Plan Review

Verification and Validation Plan

Verification and Validation Report

workstation backup and restore 


\section{Contents}

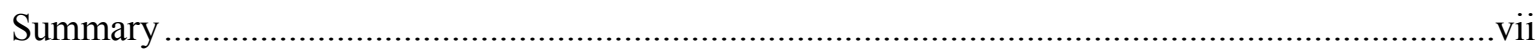

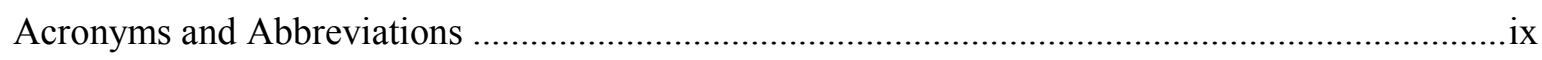

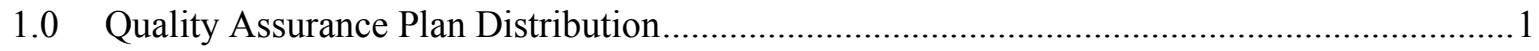

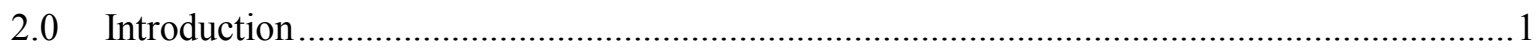

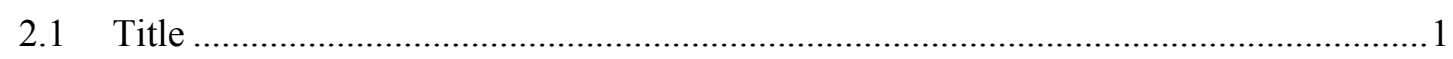

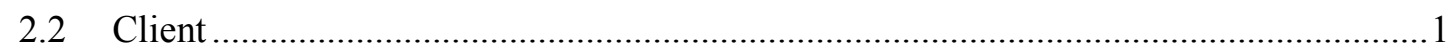

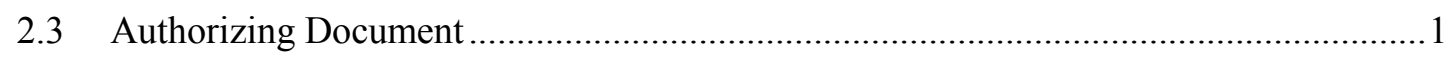

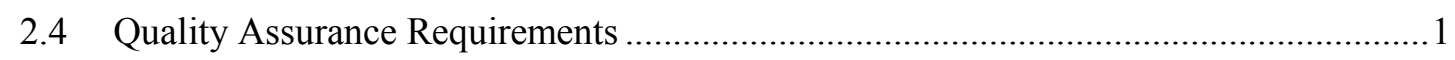

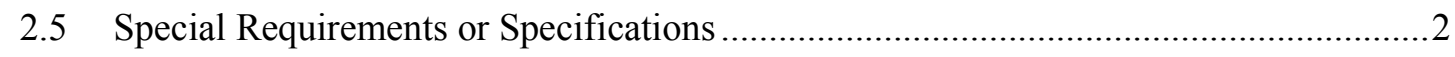

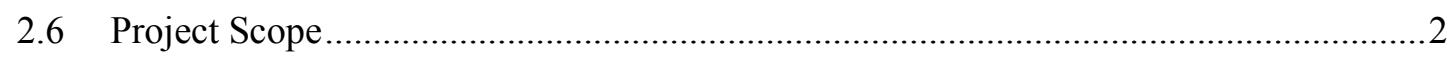

2.7 Change Control (Scope, Schedule, Budget) ….......................................................

3.0 Project Organization and Responsibilities .....................................................................

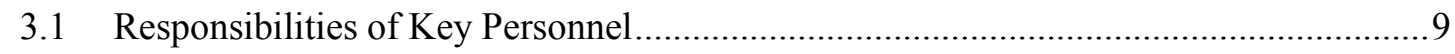

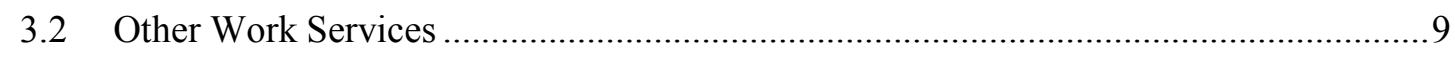

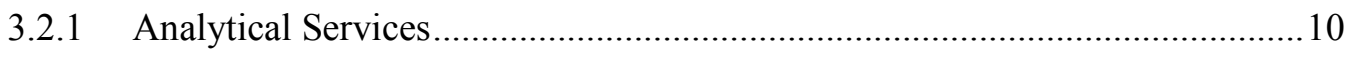

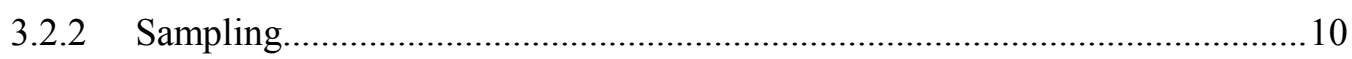

3.2.3 Well Drilling, Sampling, and Construction Services .................................... 10

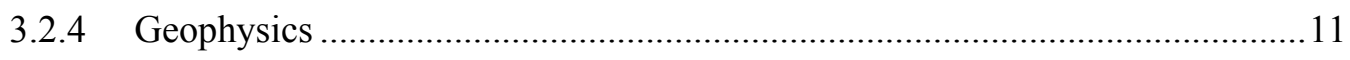

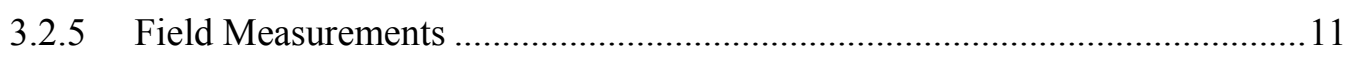

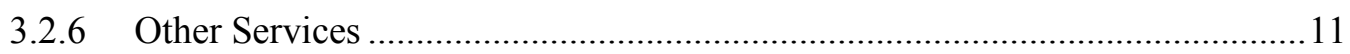

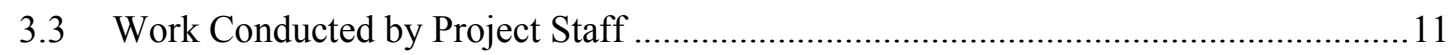

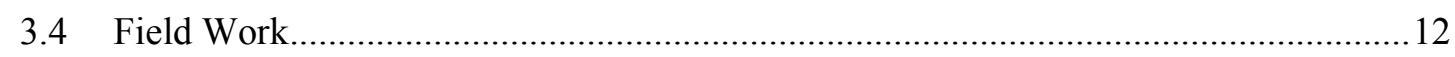

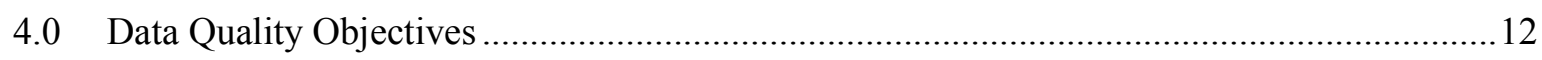

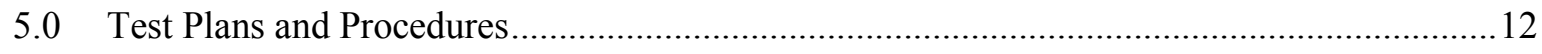

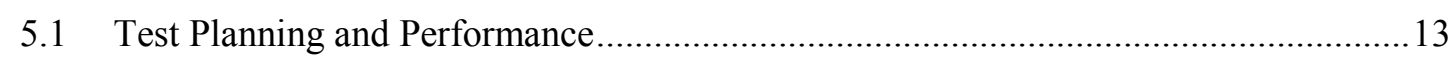

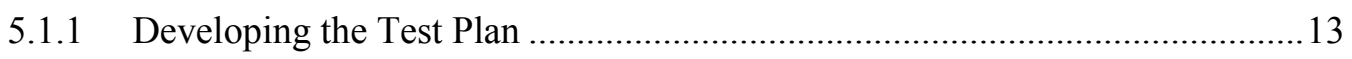

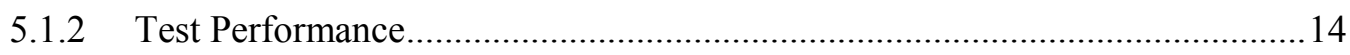

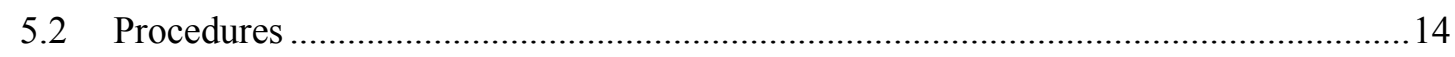

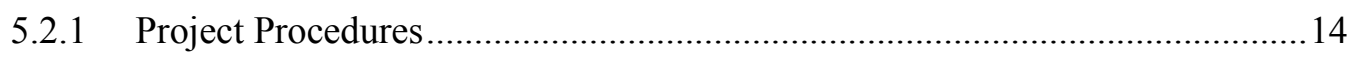

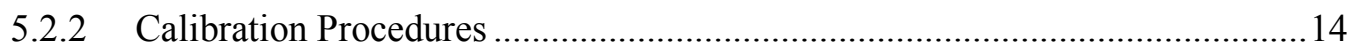

5.2.3 Common Data Quality Calculations.............................................................. 15

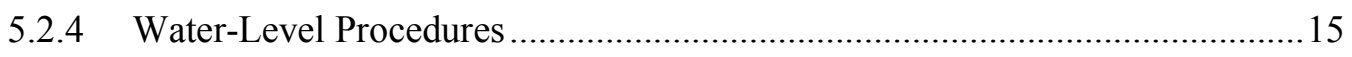

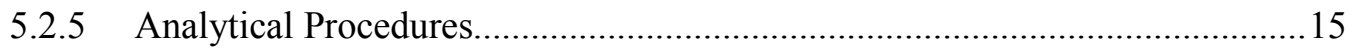

5.2.6 Well Drilling and Construction Procedures .................................................... 17

5.2.7 Water and Sediment Sample Collection Procedures .......................................17

5.2.8 Receiving and Handling Samples............................................................. 18 
5.2.9 Sediment Physical Analysis Procedures...................................................... 18

5.2.10 Sediment Core Analysis Procedures ............................................................ 18

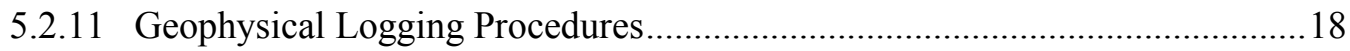

5.2.12 Geophysical Measurement Procedures........................................................ 18

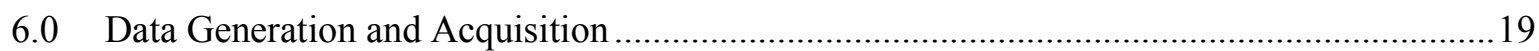

6.1 Experimental Design (Sampling Process Design) ...................................................... 19

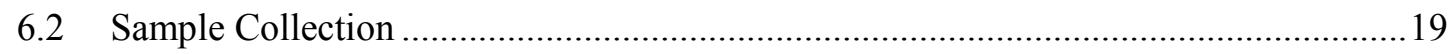

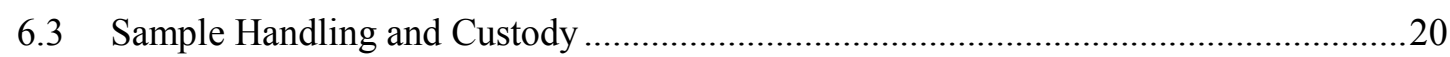

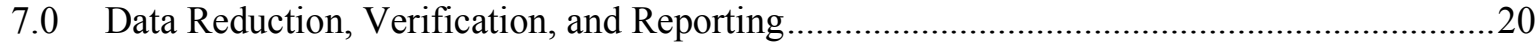

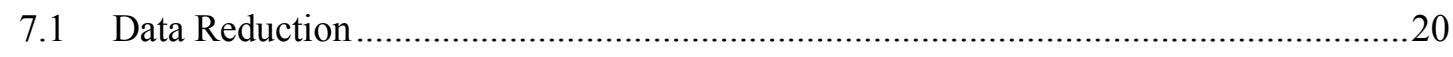

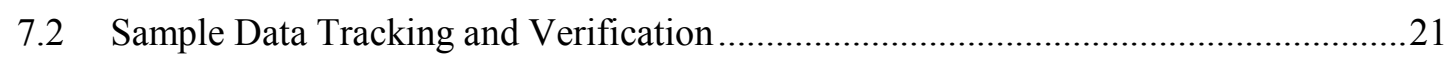

7.3 Sample Data and Tracking for Sediment and Other Media Samples ............................21

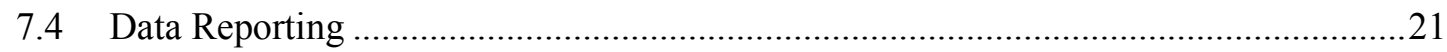

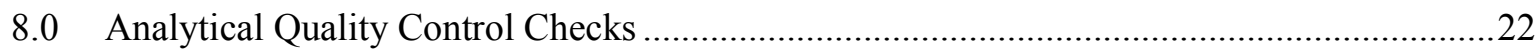

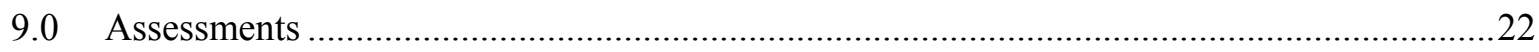

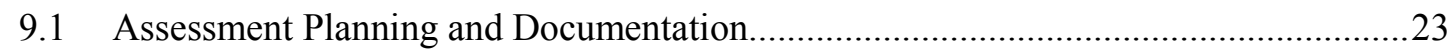

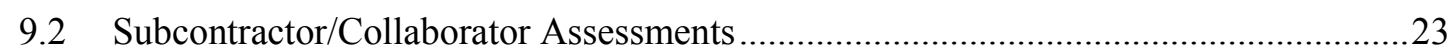

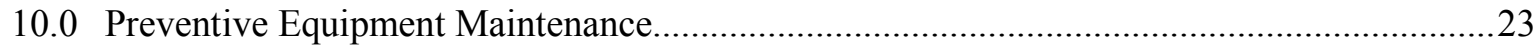

11.0 Specific Routine Procedures Used to Assess Data Precision, Accuracy, and Completeness .26

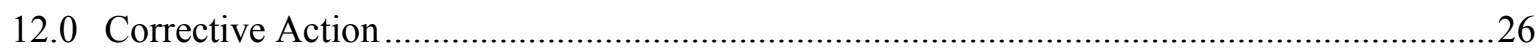

12.1 Project Corrective Actions Resulting from Assessments ...........................................26

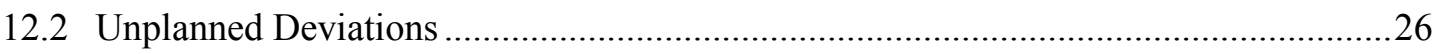

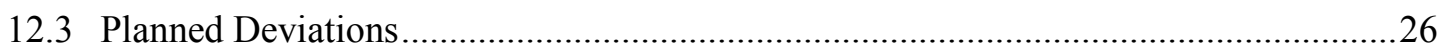

12.4 Measuring and Test Equipment Calibration Discrepancies ....................................27

13.0 Quality Assurance Reports to Management ..................................................................27

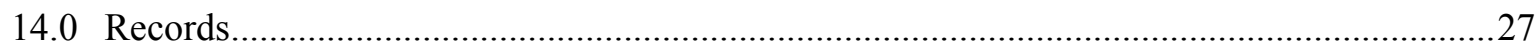

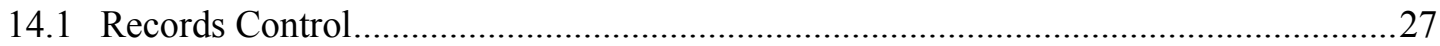

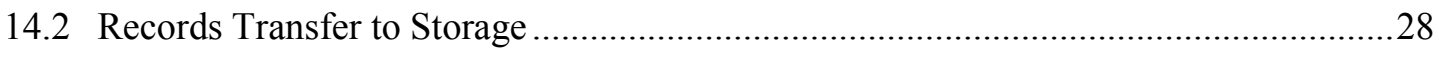

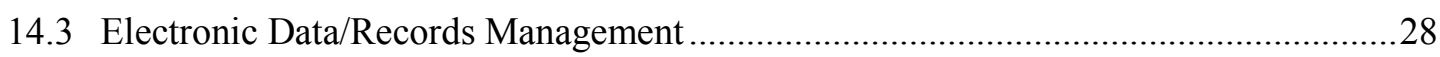

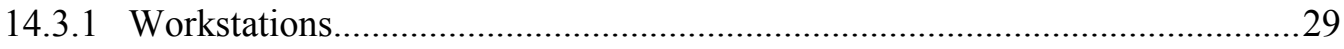

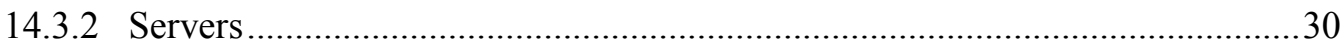

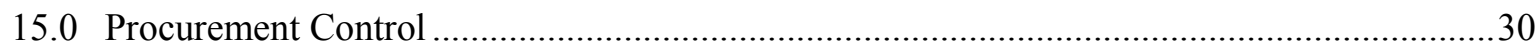

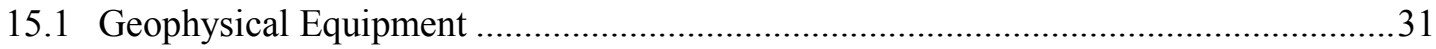

15.2 Groundwater and/or Sediment Analytical Measurements.......................................... 31

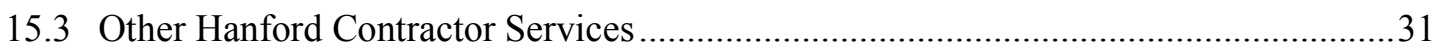

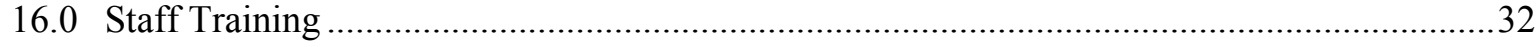

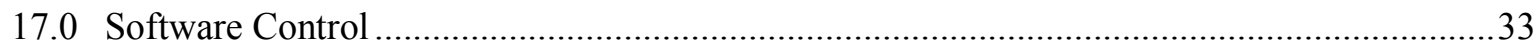

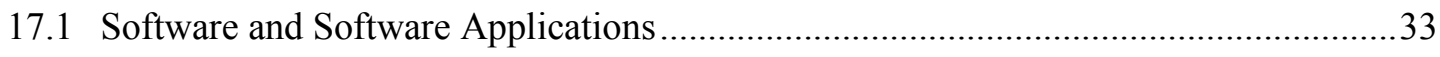

17.1.1 Minimum Documentation Requirements ........................................................33 


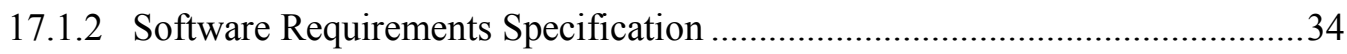

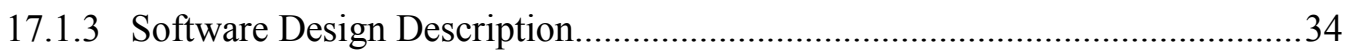

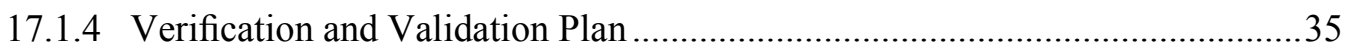

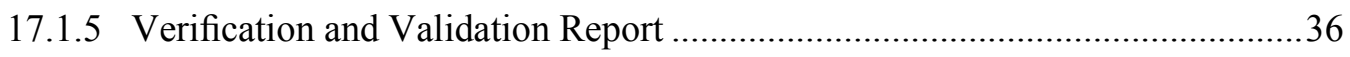

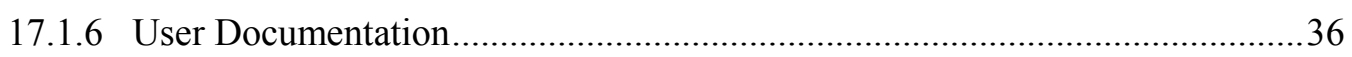

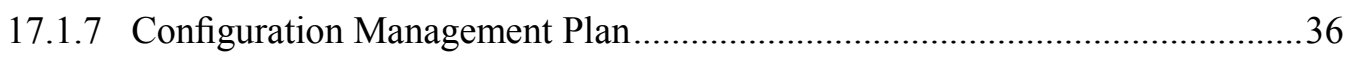

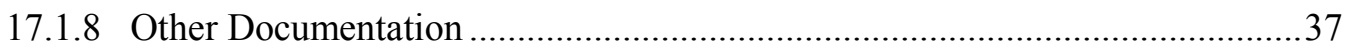

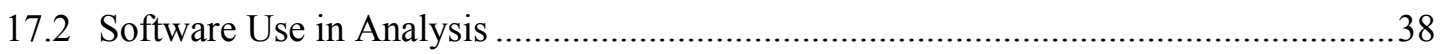

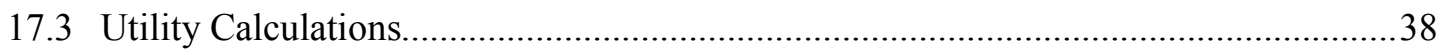

17.4 Collaborator Specific Software Requirements ...................................................... 40

17.4.1 Idaho National Laboratory ....................................................................40

17.4.2 Los Alamos National Laboratory and University Collaborator Computer Modeling Activities ..................................................................................

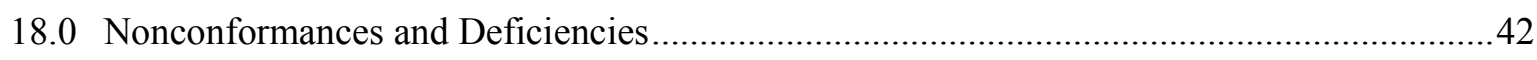

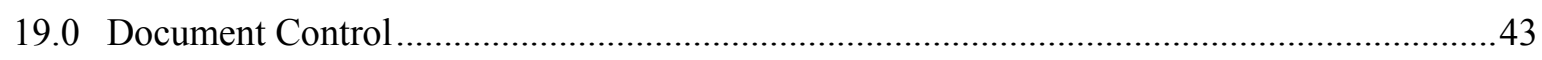

19.1 Project Quality Assurance Plan Control................................................................... 43

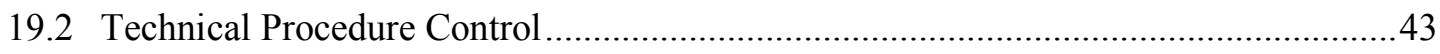

19.3 Administrative Procedure/Instruction Preparation and Control ...................................43

19.4 Test Plans and Other Work Documents ...................................................................46

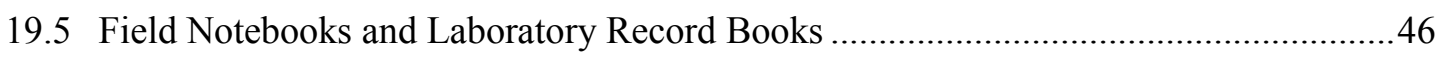

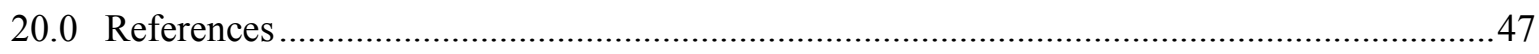

Appendix A - 300 Area IFRC Project Quality Control Plan .......................................................

Appendix B - Experimental and Modeling Procedures for the 300 Area IFRC Project............... B.1

\section{Figures}

2.1. Hanford Site Groundwater Interest Areas ........................................................................

2.2. Design of the Field Experimental Plot in the 300 Area South Process Pond............................4

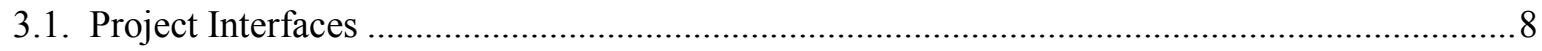

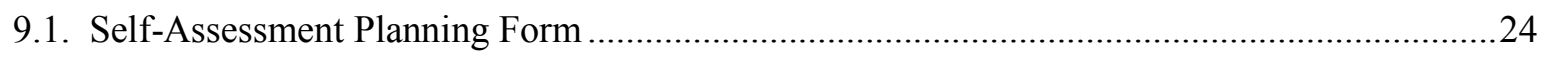

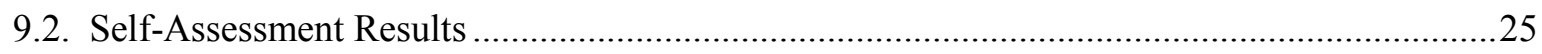

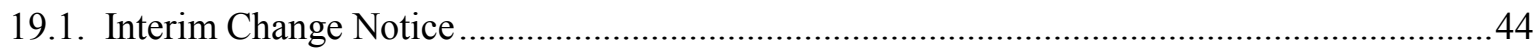

\section{Tables}

Table 17.1. Software Risk Management Example 39 



\subsection{Quality Assurance Plan Distribution}

Pacific Northwest National Laboratory (PNNL) document control will distribute this Quality Assurance (QA) Project Plan (QAPjP) internally to PNNL; the U.S. Department of Energy (DOE), Office of Biological and Environmental Research (OBER) within the DOE Office of Science; DOE Pacific Northwest Site Office, and the DOE Richland Operations Office, as requested. The Project Manager will determine the final PNNL and external distribution list. Also, the QAPjP will be published in accordance with the PNNL Standards-Based Management System (SBMS) subject area, "Publishing Scientific and Technical Information" (PNNL 2007a).

\subsection{Introduction}

\subsection{Title}

The title of the Integrated Field-Scale Subsurface Research Challenge (IFRC) project is "Multi-Scale Mass Transfer Processes Controlling Natural Attenuation and Engineered Remediation: An IFRC Focused on the Hanford Site 300 Area Uranium Plume" (referred to as the 300 Area IFRC).

\subsection{Client}

The client is the Climate and Environmental Sciences Division within OBER in the DOE Office of Science (SC) in Washington, D.C.

\subsection{Authorizing Document}

The project was issued through the Environmental Remediation Science Program (ERSP) Notice LAB 06-16. Additional funding sources are not anticipated to be issued through the duration of the contract for this work scope. However, the QAPjP will be revised, as appropriate, should conditions change. The project is scheduled to be conducted from fiscal year (FY) 2007 through FY 2013. FY 2007 through 2011 are the years scheduled for active field campaigns and FY 2012 and 2013 are scheduled for decommissioning and site closure.

\subsection{Quality Assurance Requirements}

The QAPjP is also based on the QA requirements of DOE Order 414.1C, Quality Assurance, and 10 Code of Federal Regulations (CFR) 830, Subpart A, "Quality Assurance Requirements," as described in the PNNL SBMS. The project is subject to the Price-Anderson Amendment Act (PAAA) as defined in the PNNL PAAA Program and implemented through the SBMS subject area, "Reporting Noncompliances with DOE Requirements for Nuclear Safety and Worker Safety and Health" (PNNL 2008g). Additionally, although this project conducts scientific research for the DOE OBER, one of the project goals is to publish impactful scientific results and models from the 300 Area IFRC Project to support remediation of the Hanford Site and other DOE Environmental Management sites. The scientific results and information developed by the 300 Area IFRC Project may be used as input to selection of technologies for remediation of the 300-FF-5 Operable Unit and other sites under the Hanford Federal Facility Agreement and Consent Order (Tri-Party Agreement; Ecology et al. 1989). Where this is the 
case, the Hanford Analytical Services Quality Assurance Requirements Documents ([HASQARD]; DOE/RL-96-68) apply. HASQARD requirements are discussed within applicable sections of this plan. The PNNL document for implementing HASQARD for portions of this work is Conducting Analytical Work in Support of Regulatory Programs (CAWSRP).

\subsection{Special Requirements or Specifications}

DOE Orders 435.1, Radioactive Waste Management; 5400.5, Radiation Protection of the Public and Environment; and 450.1, Environmental Protection Program, apply to the project to ensure that activities related to radioactive materials and samples are protective of human health and the environment, and fulfill PNNL environment and stewardship requirements.

Field experiment and sampling and analysis plans (see Sections 4.0 and 5.0) will be based on the scientific method, and as appropriate, application of the Data Quality Objectives (DQO) process, in accordance with the Guidance on Systematic Planning Using the Data Quality Objectives Process $(Q A / G-4)(\mathrm{EPA} / 240 / \mathrm{B}-06 / 001)$. Field experiment and sampling and analysis plans are reviewed and approved at the project level and updated as necessary.

Computer modeling and database activities for the project shall comply with the software requirements as specified in PNNL's SBMS subject areas, "Software" (PNNL 2007b) and "Safety Software" (PNNL 2008h) where applicable. Specific software requirements for PNNL and collaborator activities are described in Section 17.0 and are based on a graded approach.

\subsection{Project Scope}

The purpose of this QAPjP is to provide PNNL project staff and collaborators with the programspecific planning, execution, assessment of work and controls necessary to provide services and products of the highest quality consistent with project risks, PNNL SBMS subject area, "Battelle Policies and Standards" (PNNL 2006a) and the needs, expectations, and resources of the OBER client.

The purpose of the project is to conduct research at the IFRC in the 300 Area of the Hanford Site (Figure 2.1) and to investigate multi-scale mass transfer processes associated with a subsurface uranium plume impacting both the vadose zone and groundwater. The field site is located within the 300-FF-1 and 300-FF-5 Comprehensive Environmental Response, Compensation, and Liability Act (CERCLA) Operable Units; $300-\mathrm{FF}-1$ is the waste site operable unit and 300-FF-5 is the groundwater operable unit. The project will investigate a series of scientific questions posed for research related to the effect of spatial heterogeneities; the importance of scale; coupled interactions between biogeochemical, hydrologic, and mass transfer processes; and measurements and approaches needed to characterize a mass transfer dominated system. The research will be conducted by evaluating three (3) different hypotheses focused on multi-scale mass transfer processes in the vadose zone and groundwater, their influence on field-scale U(VI) biogeochemistry and transport, and their implications to natural systems and remediation. The project also includes goals to 1) provide relevant materials and field experimental opportunities for other ERSP researchers and 2) generate a lasting, accessible, and high-quality field experimental database that can be used by the scientific community for testing and validation of new conceptual and numerical models of subsurface reactive transport. 


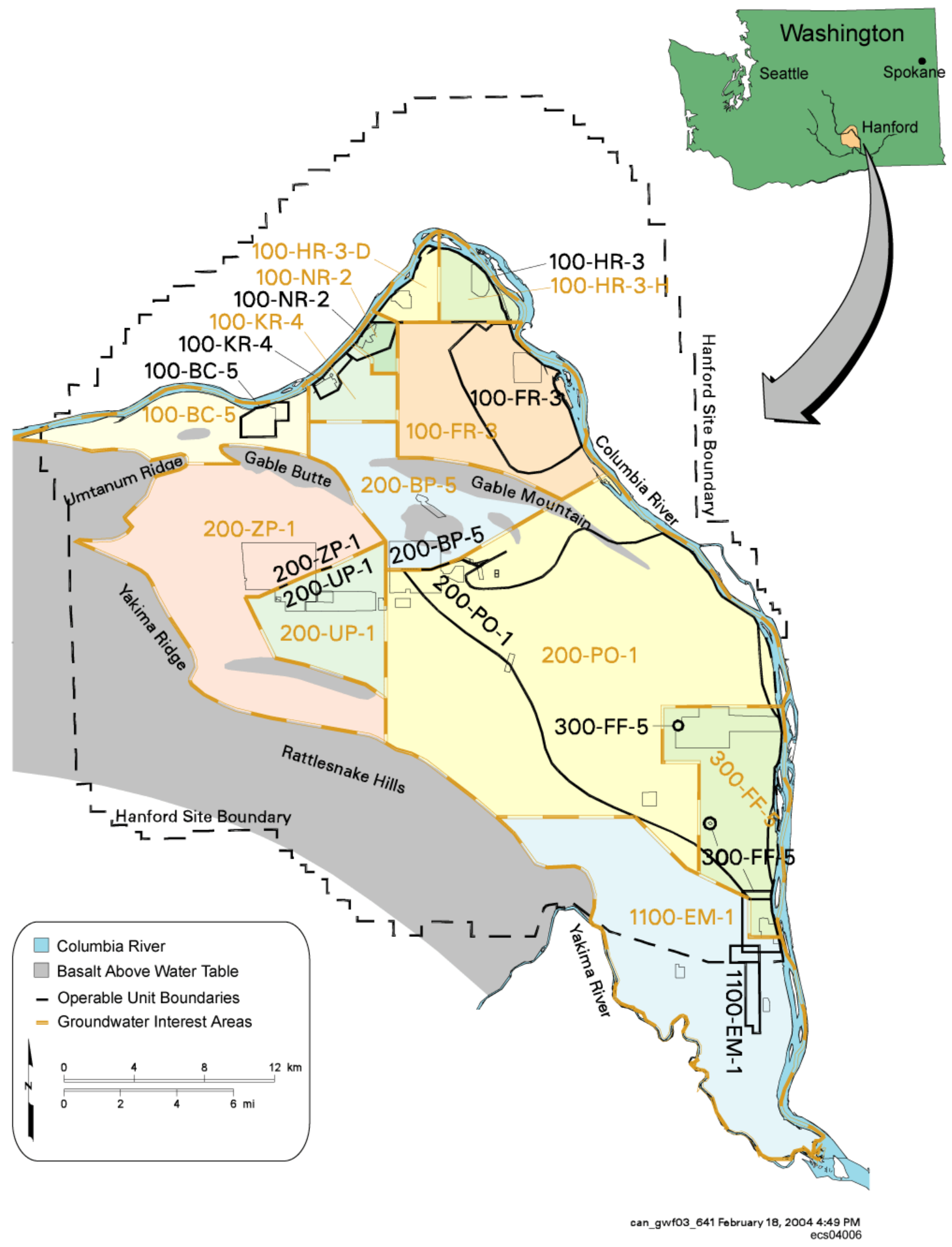

Figure 2.1. Hanford Site Groundwater Interest Areas (roughly comparable to the groundwater operable units) 
This project has established a new field experimental facility in the 300 Area south process pond (SPP) to the point of discharge into the Columbia River. Figure 2.2 shows the field site in the 300 Area SPP footprint. The facility includes a vadose zone infiltration site, a dipole-injection complex in the unconfined aquifer, and a down-gradient monitoring system.

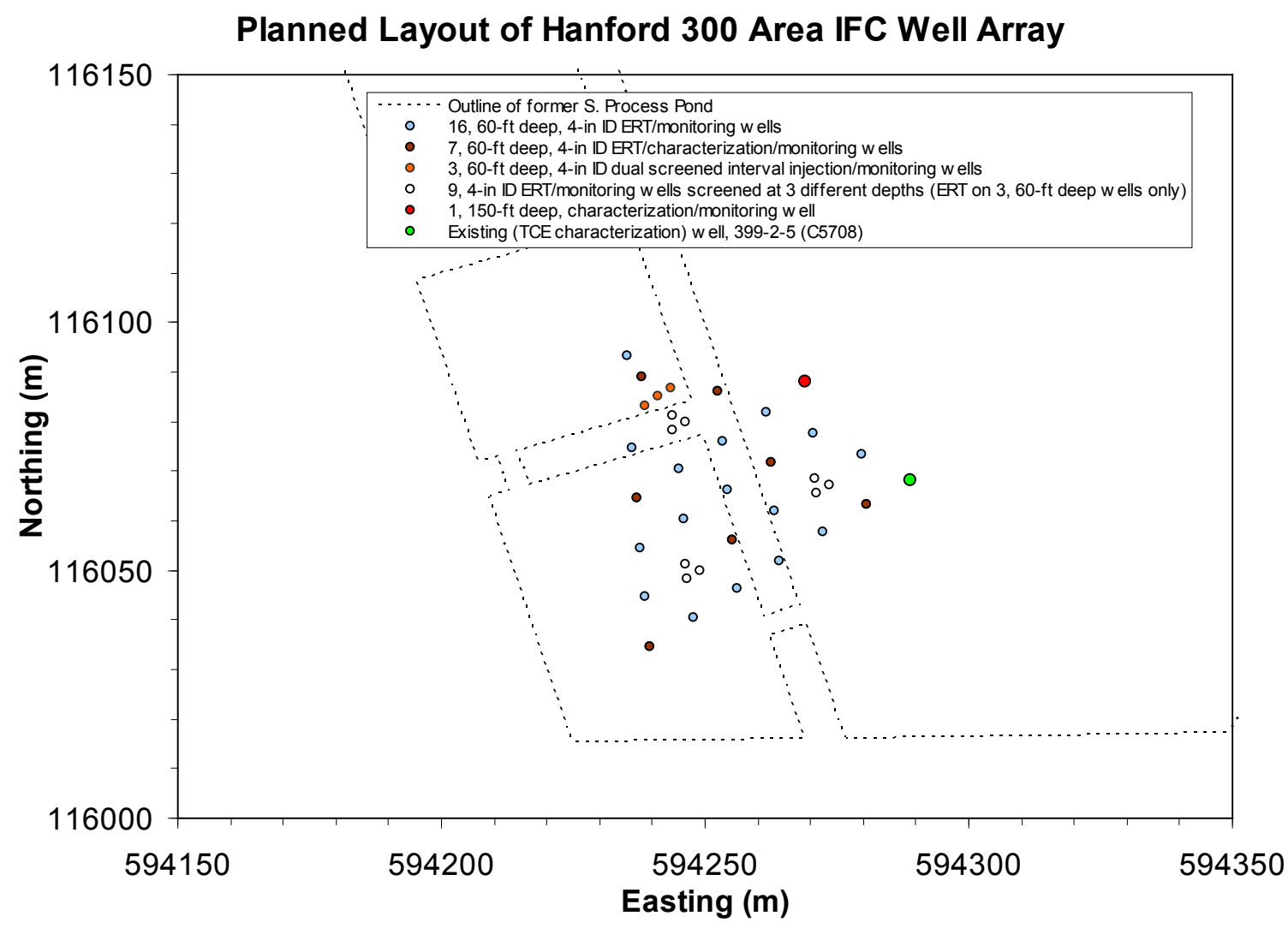

Figure 2.2. Design of the Field Experimental Plot in the 300 Area South Process Pond

The facility configuration will enable solute plumes emanating from the infiltration plot and/or injection well to be tracked during both low- and high-river stages, as well as in-between stages, which is necessary because of seasonal changes in groundwater flow direction. This well configuration will also allow for several aquifer tests and analyses to be conducted, such as tracer studies and hydraulic tomography (Yeh and Liu 2000), and incorporates recent insights derived from field studies in porous, heterogeneous aquifers (Ptak et al. 2004, Ptak and Teutsch 1994).

Four hypotheses were proposed for study; however, hypothesis 3 is not funded at this time. Should conditions change, the QAPjP will be revised to address this area of study. Therefore, the three hypotheses to be evaluated are as follows:

- Hypothesis 1: Vadose zone infiltration will solubilize sediment-bound U(VI) in response to contact time, as desorption/dissolution extent is controlled by mass transfer from intraparticle domains and export from fine-textured zones with higher U(VI) sorptivity. Vadose zone pore waters will show large variations in dissolved U(VI) because of spatial heterogeneity in the following: a) sorbed U(VI) concentrations; b) pore-scale desorption mass transfer rate; and c) the unsaturated water flow field. The highest dissolved uranium concentrations will evolve in sediment regions of intermediate texture 
and sorptivity that generally correlate with faster pore-scale mass transfer rates. Resupply of contaminant U(VI) to groundwater occurs as the water table rises into the capillary fringe and lower vadose zone, capturing U(VI) that was mobilized by infiltrating meteoric water or released locally by mass transfer controlled desorption.

- Hypothesis 2: Waste-sediment reaction and mineral weathering in mud domains between river cobble rock have created sorbent aggregates that undergo slow, mass transfer-controlled adsorptiondesorption reactions at the pore scale. Fine-grained lenses in the otherwise coarse-textured sediments are enriched in such aggregates and sorbed $\mathrm{U}(\mathrm{VI})$, and these display facies-scale, diffusive mass-transfer limitations. Accordingly, the geochemical retardation process for migrating uranium under in-situ groundwater velocities (e.g., $1 \mathrm{~m} / \mathrm{d}$ ) will be mass transfer limited and not at equilibrium. Multi-rate, mass transfer behavior will be observed for U(VI) at the field scale. Macroscopic in-situ mass transfer rates for sorbed U(VI) will decrease with transport distance as a result of heterogeneity in sorption site concentration, and plume intersection with finer-textured sediment zones. Macroscopic in-situ mass transfer rates will depend on whether desorption or adsorption is predominant.

- Hypothesis 4: The effectiveness of remedial polyphosphate additions for U(VI) immobilization will be limited by its preferential transport through permeable domains that bypass major zones of U(VI) sorption in finer-textured materials. Hydrolyzed polyphosphate will stimulate microbial growth and activity by providing a limiting nutrient, leading to changes in carbonate chemistry, $\mathrm{pH}$, and U(VI) solid-liquid distribution. Kinetic effects related to polyphosphate hydrolysis, mass transfer controlled adsorption/desorption (of uranium and polyphosphate), and diffusive transport into less permeable zones will control the rates of microbial evolution and U(VI) precipitation. Enhanced microbial activity and polyphosphate assimilation will compete with U(VI) precipitation, decreasing the formation and long-term stability of uranyl-phosphate precipitates. The relative rates of these two processes will depend strongly on the spatial distribution and physical character of the different regions where microorganisms and $\mathrm{U}(\mathrm{VI})$ reside.

The 300 Area IFRC Project will generate a readily accessible and lasting characterization and experimental data base that can be used by project participants, other ERSP investigators, and the science community, both now and in the future to test various conceptual and numerical models of subsurface transport processes.

The data management task is implementing a central web-accessible database for all samples, characterization measurements, and experimental data to enable remote collaborative efforts within the 300 Area IFRC Project team. Raw data, sampling metadata, and instrument calibration are stored to allow an auditable, reproducible link between field measurements and finalized data. A workflow-based process is established to link field data to numerical predictive models to allow reproducibility. Key elements of this approach include the following:

- A centrally managed data repository. This consists of a number of relational databases that house all data (geochemical, hydrological, geophysical, microbiological, environmental and experimental) collected as part of the 300 Area IFRC Project. These databases contain information on sensors, analytical procedures and instruments consisting of the raw data and calibration equations used. The repository also holds modeling results encoded in a netcdf format (see Rew and Davis 1990). 
- A web interface providing access. This web interface allows data access in a tiered manner. This allows the 300 Area IFRC Project scientists to publish and analyze results from ongoing experiments prior to data becoming publicly accessible. The web interface also includes tools for basic data processing and visualization (e.g., statistical analyses, time-series graphing, data contouring and three-dimensional visualization). This is implemented through a scientific workflow system as discussed in Versteeg et al. (2006).

- Automation of data acquisition and data validation. All wells are equipped with instrumentation, allowing for the high-temporal density sampling (hourly) of water level, temperature, conductivity and turbidity. In addition, these systems are designed such that auxiliary sampling probes (e.g., $\mathrm{pH}$, dissolved oxygen, and ion-specific electrodes) can readily be integrated. Data from these instruments are transmitted by wireless technology and parsed into appropriate databases. Data validation is performed to allow for rapid detection of any QA/quality control (QC) issues.

- Inventories of solid and liquid samples available to other investigators. A critical aspect of the 300 Area IFRC Project research is providing access and highly valuable samples to other ERSP investigators. The availability of such samples, their analytical characteristics, and other research results generated on them are readily traceable and linked through the web interface and associated database.

- Integration of additional data sources. Ongoing regulatory-driven data acquisition at the 300 Area has resulted in a considerable amount of data that will be used in the overall analyses of experiments performed by the 300 Area IFRC Project. These data are contained in the Hanford Environmental Information System (HEIS) and other databases that are accessed via links from the 300 Area IFRC Project data management system. In addition, a number of parallel field efforts (e.g., EM-22) will generate useful data that is linked to the 300 Area IFRC Project database.

The 300 Area IFRC Project is developing appreciable subsurface characterization data on the hydrogeology, microbiology, and geochemistry of the field experimental domain, and field results from the experimental evaluation of hypotheses 1-4. These results are further complemented with laboratory studies that seek to optimize experimental conditions for the field experiments, define pore-scale mass transfer parameters for select sediments along flow paths, and identify biogeochemical reaction and rates. All results and other relevant experimental and procedural information will be captured in the data management program, making them readily accessible to project team members and other ERSP investigators.

The Interpretational Program for the 300 Area IFRC Project has three primary objectives: 1) to develop conceptual and numeric geohydrologic, geochemical/biogeochemical, and microbiologic models of the site; 2) to develop, if necessary, new, alternative, or otherwise different mass transfer models that couple with hydrologic, geochemical, or microbiological processes; and 3) to utilize these resulting conceptual and numeric models for field experiment evaluation and hypothesis resolution using a variety of mathematical, geostatistical, and other modeling approaches practiced by the project team members. The project supports the Subsurface Transport Over Multiple Phases (STOMP) computer model as its primary, multi-process integrative model. Other multi-process models with different mass transfer formulations (e.g., MT3DMS Prommer et al. 2003) and FLOTRAN (Lichtner 2001) are being used by 300 Area IFRC Project investigators for experiment interpretation. 
The current capabilities of STOMP are well suited to the range of analyses and experiments proposed for this project: characterization of processes and properties, experimental design and interpretation, testing hypotheses and alternative conceptual models, and prediction. Code modifications are anticipated to address specialized routines for biogeochemistry and mass transfer; however, these are considered to be minor changes to existing capabilities. STOMP is being used by all current DOE-sponsored assessments of the 300 Area Columbia River aquifer vadose zone hydrologic system; thus, new knowledge in the form of characterization data and process models developed, will be directly applicable to future migration forecasts and remedial action assessments for the 300 Area U(VI) plume and other River Corridor areas at the Hanford Site.

Management processes, including planning, scheduling and execution, and providing resources for work to prepare project deliverables based on risk, safety, life cycle, and complexity are described in the Multi-Scale Mass Transfer Processes Controlling Natural Attenuation and Engineered Remediation: An IFRC Focused on Hanford's 300 Area Uranium Plume Project Management Plan (Project No. 51805, current revision).

\subsection{Change Control (Scope, Schedule, Budget)}

The project scope, schedule, and budget baseline are compiled, tracked, and reported in accordance with direction from OBER.

Changes in work scope, schedule, or budget may be necessary during the year. For those activities under the control of PNNL, changes may be requested of subcontractors and collaborators by PNNL that will result in a change to the statements of work (SOWs) due to revisions of work scope, schedule, and/or budget. These changes will be documented in revisions or addenda to the existing SOWs; additionally, a PNNL Subcontract Supplement Form shall be completed.

Administrative changes requested of subcontractors and collaborators that are approved by the Project Manager may be made by verbal or electronic messages. Written documentation of the verbal changes and electronic messages should be maintained in the permanent project files. These changes may only be made if technical work scope and budget are not significantly affected.

\subsection{Project Organization and Responsibilities}

Line authority, quality assurance authority, support within PNNL, and client interfaces are shown organizationally in Figure 3.1. Responsibilities of key personnel are summarized in Section 3.1. Changes to organizational/interface structures shown in Figure 3.1 that do not reflect a change in the overall scope of activities or a change of requirements will not require a QAPjP revision and will be incorporated into the next required revision. 


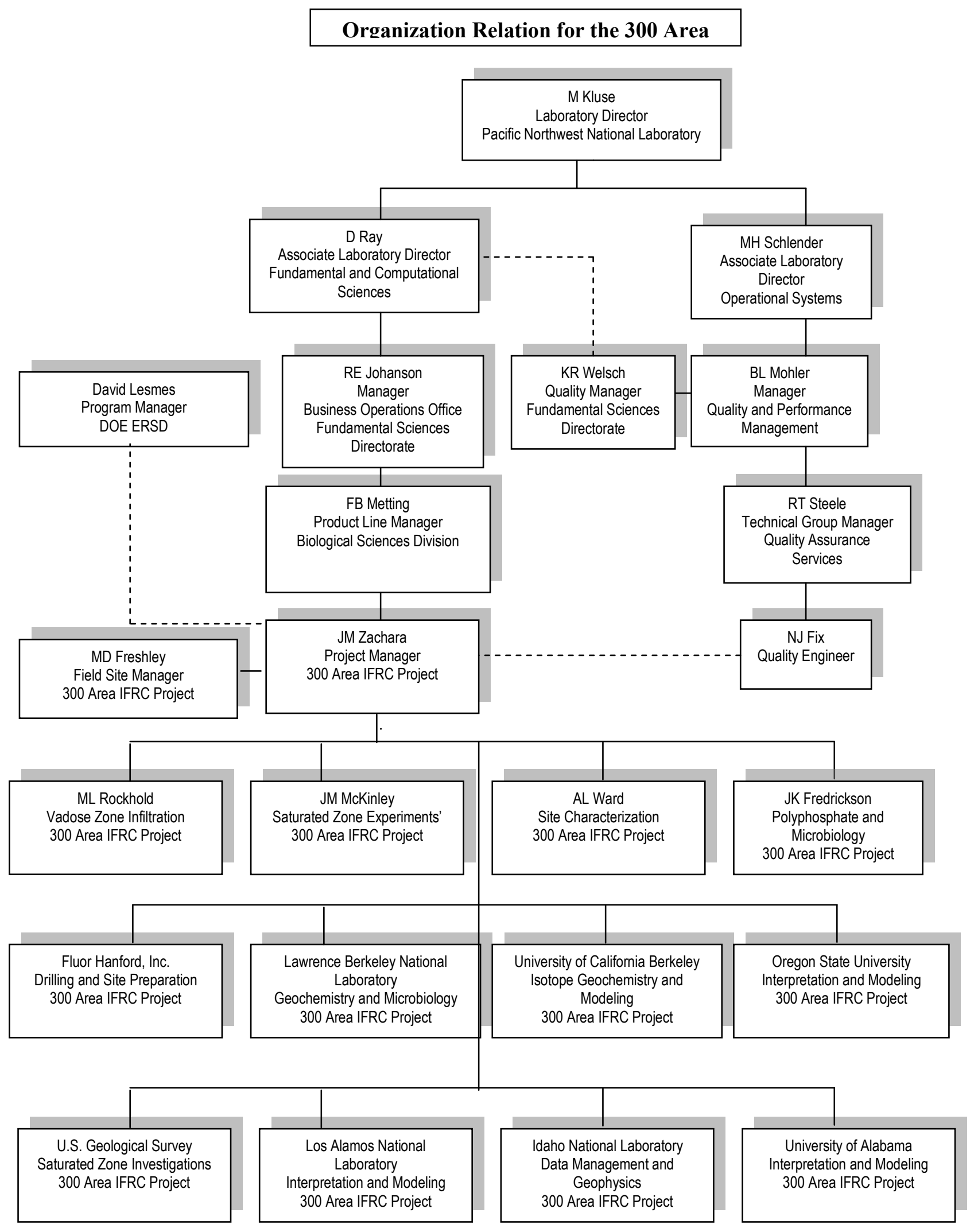

Figure 3.1. Project Interfaces 


\subsection{Responsibilities of Key Personnel}

- Project Manager and Principal Investigator (PI) - Responsible for development and implementation of the Project Management Plan (PMP), Field Site Management Plan, Communication Plan, Health and Safety Plan, and QAPjP. Serves as the primary client interface to assure that customer expectations are met in terms of quality, cost, and schedule. Provides overall direction to Task Managers and project personnel within PNNL necessary to accomplish project objectives; coordinates and executes project controls associated with scope, schedule, and budget baselines; reports on project status; assures that the project is staffed with technically qualified personnel, and assures the QAPjP is implemented.

- Field Site Manager - Responsible for 300 Area IFRC Project site operations, including obtaining applicable permits, preparing and implementing site safety plans, scheduling field activities and operations, and supervising the 300 Area IFRC Project staff and subcontractors in the field. Approves work plans for all field activities at the 300 Area IFRC Project site prior to initiation.

- Task Managers - Responsible for task-specific planning, control, communications, and progress reporting; prepares scope, resource needs, cost baseline, and deliverables; assures quality and timeliness of the work in accordance with plans, policies, and procedures; provides monthly reports; and interfaces with DOE, other contractors, subcontractors, and other Task Managers.

- Investigators - Responsible for task-specific technical plans, communications, and progress reporting to the Task Manager; prepare technical details of the task plan; assure technical quality of the work; support the Task Manager to assure work is performed on schedule, within budget, and in accordance to plans, policies, and procedures; assign and direct work of project staff; interface with DOE, other contractors, subcontractors, and other investigators.

- Project Quality Engineer - Responsible for guidance and direction to the Project Manager, Task Manager, and project staff within PNNL on PNNL QA program requirements; performs assessments to assure quality of the work; develops, updates, and approves the QAPjP; reviews and approves appropriate work plans and procedures.

- Other Project Staff - Assures technical quality of the work and that it is performed on schedule, within budget, and in accordance with plans, policies, and procedures; and reports concerns, such as unsafe conditions, and stops work as necessary.

\subsection{Other Work Services}

Other work services for various portions of project work will be through the purchasing process. General scope statements, work requirements, specifications, and quality assurance requirements are communicated via contracting mechanisms to various subcontractors (see Section 14.0). This project is funded as pure science and research by the DOE OBER; however, one of the goals of the project is to provide data and information useful to Hanford Site remediation activities during and immediately after project completion. Therefore, SOWs and test plans used for groundwater and sediment sampling, and analysis may be subject to compliance with the HASQARD (DOE/RL-96-68) and/or the EPA Requirements for Quality Assurance Project Plans (QA/R-5) (EPA/240/B-01/003), and will specify requirements to be achieved by appropriate quality documents. The determination of whether compliance with these requirements is required will be made on a case-by-case basis based on a graded approach. 
The statement of work (SOW) will include instructions for inspecting/accepting supplies and consumables used for this project.

Subcontracts for drilling, sediment sampling, groundwater sampling, and associated support activities will include the following:

- CH2M Hill Plateau Remediation Company, LLC (CHPRC) - Performs drilling, sediment and water sample collection related to drilling, and well construction services.

- Other subcontractors - May provide civil surveys, special analytical services, or other services.

\subsubsection{Analytical Services}

PNNL project participants providing analyses of sediment and water samples are responsible for preparing data reports that summarize the results of analyses, and detailed data packages that include the following:

- Sample receipt and tracking documentation, including identification of the organization and individuals performing the analysis; names and signatures of the responsible analysts; sample holding time requirements; references to applicable chain-of-custody procedures; and dates of sample receipt, extraction (if applicable), and analysis.

- Quality control data, as appropriate for the methods used, including (as applicable) matrix spike/matrix spike duplicate data, recovery percentages, precision and accuracy data, laboratory blank data, and identification of any nonconformance that may have affected the laboratory's measurement system during the time period in which the analysis was performed.

- Analytical results or data deliverables, including reduced data and identification of data qualifiers and contractually defined reporting comments.

These requirements, as well as QA and technical requirements, are specified in the SOW to the other national laboratories and university project participants as necessary.

\subsubsection{Sampling}

The individual or organization collecting soil or water samples — generally PNNL — is responsible for 1) obtaining the samples; 2) delivering samples to the laboratory; and 3) delivering completed paperwork for implementing sample tracking. Activities associated with the sample collection, sample handling, sample labeling, and custody of the samples in the field should be consistent with the recommendations and protocol provided in Chapter 4, Section 4.2 through 4.4 in RCRA Ground Water Monitoring Technical Enforcement Guidance Document (National Water Well Association 1986), Test Methods for Evaluating Solid Waste: Physical/Chemical Methods, SW-846 (EPA/SW-846), and the Handbook for Analytical Quality Control in Water and Wastewater Laboratories (EPA-600/4-79/019).

\subsubsection{Well Drilling, Sampling, and Construction Services}

CHPRC provides well-drilling and construction subcontractors and oversight of Hanford Site activities. For the 300 Area IFRC Project, CHPRC is responsible for 1) well-drilling design 
specifications and contract management, 2) site preparation and documentation requirements, 3) sediment and water sample collection during drilling, 4) supporting hydrologic tests conducted during drilling, and 5) well construction, development, and sample pump installation. Well construction will meet the requirements of Washington Administration Code (WAC) 173-160. Well drilling and construction, sediment and water sampling, testing support, and associated quality requirements will be specified in the CHPRC SOW. CHPRC may subcontract work activities, provided the requirements in the SOW and the CHPRC QA Program are met by subcontractor(s).

\subsubsection{Geophysics}

CHPRC is responsible for obtaining geophysical logging services from S.M. Stoller during well drilling. PNNL provides technical support to CHPRC to ensure that the geophysical logging requirements and associated quality requirements are specified in the SOW. Requirements for data deliverables are also specified in the SOW.

Other geophysics activities are provided by PNNL, external collaborators on the 300 Area IFRC Project, or subcontractors. PNNL and/or the collaborators are responsible for performing these geophysical services. PNNL provides technical support to the collaborators to ensure requirements and associated quality requirements and data deliverables are specified in the SOW to the proposed subcontractor.

\subsubsection{Field Measurements}

Field measurements during well drilling will be conducted in accordance with CHPRC procedures during well drilling, other equivalent procedures, and as directed in the SOW. The 300 Area IFRC Project-specific test plans that have been reviewed and approved will address procedures during field experiments.

\subsubsection{Other Services}

Other subcontracted services received from CHPRC, other Hanford Site contractors, or others may include construction of fences and enclosures, geophysical logging, etc.

\subsection{Work Conducted by Project Staff}

Analytical activities conducted by staff in support of the 300 Area IFRC Project shall be conducted in accordance with procedures documented in test plans associated with experiments, as appropriate. Field measurements will be conducted in accordance with in-house operating procedures. Project staff are responsible for identifying data qualifiers and preparing data reports that summarize analyses results, and quality control data for the method used. The results and raw data will be included in the project records.

Project staff will conduct sampling and measurements according to written and approved test plans (Section 5.1), written procedures, or other written direction. 


\subsection{Field Work}

Field work is the primary component of the 300 Area IFRC Project. Prior to executing field work, project-specific test plans are developed, as described in Section 5.0. If supplemental information or individual parameters are needed to perform a test, a test instruction will be developed. The test instruction shall be reviewed by technical staff and the project Quality Engineer.

\subsection{Data Quality Objectives}

The QA objectives for measurements generally applicable to scientific investigations under the purview of this QAPjP are primarily related to the following: 1) the definition of appropriate methods, and analytical precision and accuracy appropriate for chemical analysis of the analyte of interest; and 2 ) the definition of methods, limits, and values for physical measurements associated with the investigation (e.g., column tests). Discussions of aqueous sample analytical objectives and analytical methods with corresponding target values for detection limits, precision, and accuracy are provided in Appendix A of this QAPjP, the Environmental Sciences Laboratory QA Plan (QAP ESL, current revision), individual test plans, and/or test procedures. The sediment analytical objectives and analytical methods with corresponding target values for detection limits, precision, and accuracy are provided in the Environmental Sciences Laboratory QA Plan, individual test plans, and/or test procedures. Where appropriate, DQOs developed in accordance with Guidance on Systematic Planning Using the Data Quality Objectives Process (QA/G-4) (EPA/240/B-06/001) will be applied. Other measurement objectives and methods with corresponding target values for detection limits, precision, and accuracy (as applicable) are provided in the specific work plans and/or the SOW for such activities. Specific data quality needs for individual investigations that differ from the requirements established herein shall be addressed within individual work plans. Other measurement considerations, accuracy requirements, units, and data recording and reporting protocols for instruments supporting stratigraphic characterization, aquifer testing, and other types of field investigations shall be as specified in the applicable plans and/or procedures. Because of the dynamic nature of field experiments, some field measurements, samples, and tests will be conducted in response to unpredicted test conditions. Under these circumstances, special measurements and samples will be documented as performed.

\subsection{Test Plans and Procedures}

Test plans and procedures are used to assure that activities affecting quality are performed consistently and correctly. Test plans are prepared by project staff to conduct a single experiment or test, as identified in the following sections. These plans must be consistent with safety, training, National Environmental Policy Act of 1969, and regulatory requirements and shall receive independent review for overall scientific approach, technical details, and health and safety.

Because linkage of laboratory experiments to field experiments is an important part of this project, laboratory experiments will be done following documented procedures or test plans will be generated. These plans are expected to be less detailed than field plans. 


\subsection{Test Planning and Performance}

Test plans will be used to document a single or related set of experiments or tests (e.g., hydrologic field tests, vertical sampling) work activity.

\subsubsection{Developing the Test Plan}

The test plan shall contain the following information:

- A title and/or number including date or revision.

- Dated signatures of the preparer, technical lead, project manager or task manager, and quality engineer.

- Individual page identification (page __ of __ ).

The content of each test plan will depend on the scope of the test. The following is a brief description of mandatory and optional items to be considered in the preparation of the test plan:

- Purpose/Description (mandatory) - Provide a short narrative on the purpose of the experiment, test, or activity.

Example: The purpose of this test is to provide hydrologic property data at polyphosphate treatability injection test wells.

- Prerequisites (mandatory) - List items, conditions, or other concerns that must be satisfied prior to beginning the test.

Example: Prior to beginning the work activity, the staff must complete special training on other plans or procedures that will be used in conjunction with the test plan, special handling or storage requirements, special access or permits, and required records that need to be generated as the result of the work activity.

- Safety (mandatory) - Describe the hazards associated with the work such as physical agents (e.g., temperature, pressure, noise, electrical); hazardous environments (e.g., confined spaces, remote locations, heat/cold stress); and hazardous materials (e.g., flammables, corrosives, highly toxic, carcinogens). Describe the methods used to mitigate the hazards that were identified (e.g., personal protective equipment, time periods away from the hazard, alarms, location of nearest aid station).

- Materials and Equipment (optional) - List the materials and equipment that are necessary to complete the work.

- Measuring and Test Equipment (mandatory) - List the equipment that will be used to make the measurements; include the calibration requirements, system checks, and quality control checks in this section, or in the work instructions section of the test plan.

- Pretest Verification (mandatory) - Determine if certain items of a test require verification prior to their use and indicate how the verification will be done.

Example: A tracer solution containing Br will be used throughout the test and the initial concentration shall be known. The solution shall be measured by the calibrated probe (as described above) and the concentration shall be recorded prior to injection. 
- Documentation and Reporting (mandatory) - Describe where the data collected during the test should be documented (e.g., field record forms, laboratory record books (LRBs), entered into a computer, downloaded from computer to hardcopy). Additionally, describe what will be reported, to whom, and the due date(s).

- Work Instructions (mandatory) - Provide step-by-step instructions and/or non-sequential instructions (whichever is most appropriate to the activity). Each step or instruction shall be as simple as possible but with sufficient detail so that individuals experienced in the technology or activity involved can easily understand. The following types of information should be considered for inclusion: administrative-control hold points (i.e., where safety, quality, radiological, or other approvals or actions are required before proceeding); cautions that indicate potentially hazardous situations which, if not avoided, may result in death, injury, or damage to facilities or equipment; and notes that call attention to supplemental information that assist the user in making decisions or improving work performance.

\subsubsection{Test Performance}

Tests will be performed in accordance with the test plans, which shall be available at the work location. The Technical Lead is responsible for assuring that the current version is used to perform the work.

If changes to the test plan are required during the execution of the work, the Technical Lead shall document the deviation and the justification or rationale for the change.

\subsection{Procedures}

Procedures will be developed in accordance with the SBMS subject area, "Procedures, Permits, and Other Work Instructions" (PNNL 2004). Project staff will perform scheduling, data verification, data processing, and data management, as described in Section 6.0 and by following the applicable internal technical procedures or instructions.

\subsubsection{Project Procedures}

Procedures used by PNNL project staff will be developed in accordance with the SBMS subject area, "Procedures, Permits, and Other Work Instructions" (PNNL 2004). Project staff will perform scheduling, data verification, data processing, and data management as described in Section 6.0 and by following applicable internal technical procedures or instructions. Also, project staff will perform groundwater sampling, field measurements, water-level measurements, and aquifer testing by following the appropriate internal technical procedures.

\subsubsection{Calibration Procedures}

The requirements for calibrating field and analytical laboratory instruments and maintaining traceability to national or international standard (e.g., National Institute of Standards and Technology) is in accordance with Test Methods for Evaluating Solid Waste: Physical/Chemical Methods, SW-846, Third Edition (EPA/SW-846, as amended) and HASQARD (DOE/RL-96-68). These requirements are 
passed to the subcontractors by a SOW. PNNL will periodically assess the use and effectiveness of procedures and systems for calibration of equipment with the subcontractors.

Measuring and test equipment (M\&TE) used by PNNL staff to collect quality-affecting data that are calibrated by the user (Category 2 M\&TE) or by an approved external or internal source (Category 1 M\&TE) will be in accordance with the SBMS subject area, "Calibration" (PNNL 2005). Upon receiving calibrated equipment, staff must review the documentation for acceptability and verify the proper operation of the M\&TE and check the calibration label.

M\&TE shall be controlled as described in CAWSRP), Section 4, "Instrument Calibration," and in accordance with the SBMS subject area, "Calibration" (PNNL 2005). Externally calibrated M\&TE, such as balances, will be calibrated in accordance with the manufacturer's tolerances unless other control limits are specified and justification is provided.

Data sheets and log book entries will be used to document pipette performance checks. Calibration reports and other calibration data will be maintained as project records.

Quality control requirements are described in CAWSRP, Section 5, "Quality Control," and in Appendix A of this QAPjP. A few exceptions to $\underline{\text { CAWSRP }}$ requirements are considered necessary for the project, as described in the following paragraphs.

\subsubsection{Common Data Quality Calculations}

Data quality parameters of precision, accuracy, measures of agreement, detection limits/sensitivity, and uncertainty will be calculated in accordance with the formulae in CAWSRP, Section 6, in the exhibit, "Calculations for Assessing Data Quality." For radiochemistry analyses, the minimum detectable activity (MDA) is reported as the detection limit.

The CAWSRP exhibit, "Calculations for Assessing Data Quality," describes control charting as a tool used to monitor an ongoing/continuous process where there are sufficient data points to perform a representative statistical evaluation. The analyses performed within this project are performed as a research function in which instrumental operating parameters may be changed to accomplish many different objectives. The frequency of instrumental operating changes does not allow accumulation of sufficient data points to properly utilize control charting as a statistical analysis tool. In lieu of control charts, instrument performance is monitored daily by the use of fixed control limits.

\subsubsection{Water-Level Procedures}

Procedures for water-level measurements shall be written in accordance with industry-accepted standards, such as guidelines prepared by the U.S. Geological Survey (USGS 1977), and updated as required for the latest advances in measuring equipment.

\subsubsection{Analytical Procedures}

The specific work plans and/or test plans identify the constituents to be analyzed. As applicable, sampling and analysis plans are documented in a test plan (e.g., chain-of-custody form), including 
specification of analytical methods, sample identification, and other information. The chain-of-custody form and samples are provided to the appropriate PNNL staff member or offsite laboratory.

Administrative quality assurance processes and procedures (e.g., chain-of-custody, custody logs, sample handling, storage and disposal, training) will be required of the onsite and offsite laboratories and will be specified SOWs as appropriate. The analytical methods required may be contained within the following references:

- Test Methods for Evaluating Solid Waste: Physical/Chemical Methods, SW-846, Third Edition (EPA/SW-846, as amended)

- Methods for Chemical Analysis of Water and Wastes (EPA-600/4-79-020)

- Prescribed Procedures for Measurement of Radioactivity in Drinking Water (EPA-600/4-80-032)

- Procedures for Radiochemical Analysis of Nuclear Reactor Aqueous Solutions (EPA-R4-73-014)

- Radiochemical Analytical Procedures for Analysis of Environmental Samples (EMSL-LV-0539-17).

Many radiochemical methods have not been standardized, but the procedures are documented in the laboratory-specific standard operating procedures. Aqueous sample chemical and radiological analytical methods and requirements for constituents are specified in the SOW, work plan, or other written direction, including specification of detection limits.

Most potential constituents to be analyzed are provided in Appendix A, Table A.3 of this QAPjP and/or the Environmental Sciences Laboratory QA Plan (QAP ESL, current revision). Sediment and other media constituents to be analyzed and corresponding analytical methods and procedures will be passed on to the analytical laboratory by a SOW, work plan, or other written direction.

Sediment constituents to be analyzed for, as well as the corresponding analytical methods and procedures, will be documented. The method detection limits for sediment analysis shall be determined using the calculation provided in Chapter One of EPA/SW-846 (as amended).

Technical procedures not previously documented will be developed and used as described in CAWSRP (2008), Section 7, "Procedures." If supplemental information or individual parameters are needed to perform a test, a test instruction will be developed. The test instruction shall be reviewed by a technical reviewer and must include the following information:

- A unique numerical designation

- Revision number

- Title

- Effective date

- Instructions - operating parameters and specific test run information such as sample size and/or composition, temperature, $\mathrm{pH}$, test duration, etc.

- Reference to controlling procedure or test plan

- Approval by author 
- When well-established methods (e.g., American Society for Testing and Materials [ASTM], Soil Science Society of America, or U.S. Environmental Protection Agency) are used, a PNNL cover page will not be provided unless there is a deviation from the established method.

Appendix B of this QAPjP lists additional analyses and measurements with the respective procedures, methods, and other relevant information.

Administrative quality assurance processes and procedures (e.g., chain-of-custody, custody logs, sample handling, storage and disposal, training) will be required from the onsite and offsite analytical laboratories and will be specified in the SOW.

\subsubsection{Well Drilling and Construction Procedures}

CHPRC will obtain drilling services through their procurement process. SOWs to CHPRC will be used to specify well drilling, characterization (aquifer and sediment sampling, etc.) and construction requirements. The well drilling, sediment samples collection, groundwater samples collection, water level measurements, and notification to perform geophysical logging/gyroscope well deviation survey are the responsibility of CHPRC. These activities will be performed to CHPRC procedures and/or to subcontractor procedures (e.g., conducting geophysical logging/gyroscope well deviation survey). CHPRC Health and Safety, and applicable quality assurance and waste management procedures will be followed during the drilling activity.

\subsubsection{Water and Sediment Sample Collection Procedures}

Groundwater sampling conducted for this project will be performed by 300 Area IFRC Project personnel. To assure that samples of known quality are obtained, project staff will be required to use controlled procedures based on standard methods for groundwater sampling whenever possible. Assessments will be performed by PNNL to further assure that procedures are followed to maintain sample quality and integrity (see Section 8.0).

Procedures will be designed to reduce variability between sampling events and obtain representative samples, thereby maintaining consistent quality. The quality of sampling operations is important to the ultimate quality of the data that will be obtained. To assure that samples of known quality are obtained, controlled procedures based on standard methods for sediment and water sampling will be used, whenever possible. The 300 Area IFRC Project PI or designee and project Quality Engineer will review and approve procedures before use to ensure technical quality and consistency. In many cases, existing procedures will be used and incorporated into test plans by reference. Assessments will be performed to assure that procedures are followed to maintain sample quality and integrity (see Section 8.0).

Sediment and water samples collected during drilling will be collected by or under the direction of CHPRC, and in accordance with CHPRC or subcontractor procedures. The quality requirements for sampling activities, including chain-of-custody, storage, and records requirements are specified in the SOW (or well data sheet). Sample bottle preparation, sample analysis, and preparing associated paperwork is conducted by PNNL in accordance with PNNL internal procedures. 


\subsubsection{Receiving and Handling Samples}

Direction for sample handling and storage is provided in CAWSRP, Section 3, "Receiving and Handling Samples," and in the SBMS subject area, "Sample Handling, Archival, and Disposal" (PNNL 2008i).

Chain-of-custody for samples will be documented using a chain-of-custody form. An example of a chain-of-custody form is provided as an exhibit in CAWSRP. Each PNNL facility is a secured area, restricted to authorized personnel only. Chain-of-custody will be documented for moving samples from one facility to another, but not for moving samples within a secured facility, or for samples analyzed at the field site or hand-carried from the field site to the Environmental Sciences Laboratory. Samples handled according to this process will be documented in the onsite field LRB or data sheets.

Disposition of unused materials may include returning the material to PNNL or disposal at the facility performing sample analysis. Material returned to the client will be documented by a chain-of-custody. Material disposed of at PNNL will be documented by standard waste paperwork (forms). See the SBMS subject area, "Waste, Managing" (PNNL 2008j).

\subsubsection{Sediment Physical Analysis Procedures}

Sediment physical analyses including moisture content, particle-size distribution, hydraulic conductivity, water retention, water content, bulk density, particle density, and matric potential will be performed as directed in test plans developed by PNNL staff. Sediment physical analysis procedures are described in the internal Procedures for Ground-Water Investigations (PNL-MA-567) or on project-specific internal procedures for groundwater.

\subsubsection{Sediment Core Analysis Procedures}

Sediment core analyses and column experiments will be performed by project participants as described in the test plans. The individual test plans will either provide a written procedure or reference an existing procedure. Alternatively, for specialized analyses under development as part of scientific activities on the project, procedures may be documented as developed during sample analysis. Such procedures will be documented as described in Section 5.2.5 when work is completed.

\subsubsection{Geophysical Logging Procedures}

Geophysical logging and gyroscope well-deviation surveys during well drilling will be performed by S.M. Stoller using its procedures, and as directed in the SOW. All other geophysical logging procedures will be performed according to documented test procedures.

\subsubsection{Geophysical Measurement Procedures}

Geophysical analyses may be used for data collection and analysis as part of the 300 Area IFRC Project. Geophysical techniques currently planned for use include the following:

- Electrical resistivity tomography (ERT) 
- Cross borehole seismic

- Neutron probes

- Cross borehole ground penetrating radar

These measurements will be conducted by PNNL staff or subcontractors, as appropriate. Measurements conducted by PNNL staff shall be performed as directed in the test plan. In addition, procedures are contained in individual test plans, which will either provide a procedure or reference an existing procedure. Measurements conducted by subcontractors shall be performed as directed in a SOW issued by PNNL and in accordance with the subcontractor's procedures.

Currently, no ASTM- or community-accepted QA/QC standards exist for ERT. However, EPA and the USGS have developed recommendations of "best practices" for both resistivity tomography field procedures and data analysis (see Johnson et al. 2008). The test plans developed for implementation of ERT processes shall document the collection of reciprocal or repeat data to quantify measurement errors; selection of data-collection parameters, such as number of stacks and time windows; checks for outlier data and bad electrodes or channels; and selection of inversion parameters to prevent incorrect fitting of data.

\subsection{Data Generation and Acquisition}

\subsection{Experimental Design (Sampling Process Design)}

The data generation and data collection designs for the 300 Area IFRC Project experiments will be documented in individual test plans or sampling and analysis plans.

Routine sampling processes used to support the 300 Area IFRC Project research will be consistent with the scientific objectives of the project and where necessary, consistent with the waste management area sampling design, based on the regulatory requirements (e.g., Resource Conservation and Recovery Act of 1976 or CERCLA) and applying the Data Quality Objectives Process in accordance with Guidance on Systematic Planning Using the Data Quality Objectives Process ( $Q A / G-4)$ (EPA/240/B-06/001). A description of these processes will be included in test plans along with the number of samples, sampling schedule, number of sample locations, number of quality control samples (field replicates, etc.), analysis methods and quality control criteria, and groundwater-level measurements.

\subsection{Sample Collection}

The procedures for collecting samples and identifying the sampling methods and equipment, including any implementation requirements, sample preservation requirements, decontamination, and materials needed for projects involving physical sampling will be followed during sample collection. If a failure in the sampling or measurement system occurs, the failure and recovery will be documented in a project-specific LRB or controlled field book. The 300 Area IFRC Project Manager or his designee is responsible for ensuring that the corrective action is effective and documented. 
The preparation and decontamination of sampling equipment, including the disposal of decontamination by-products; the selection and preparation of sample containers, sample volumes, and preservation methods; and maximum holding times from sample extraction to analysis will be managed in accordance with EPA/SW-846 (1986, as amended) or PNNL-specific procedures, as applicable. Waste generated as a result of the activities will be handled in accordance with the SBMS subject area, "Waste, Managing" (PNNL 2008j).

Field sample collection, if applicable, will be done by PNNL or 300 Area IFRC Project staff to specific procedures and test plans. PNNL will prepare, integrate, and coordinate sample collection schedules and constituent analysis of samples in accordance with experimental plans and procedures. The paperwork and instructions provided to the field personnel will include chain-of-custody forms, labels, and sample reports.

\subsection{Sample Handling and Custody}

Custody of the samples collected by 300 Area IFRC Project staff in the field and receipt at the laboratory will be documented in the chain-of-custody forms in accordance with PNNL procedures. Additionally, shipping and transporting of the samples will be handled by PNNL staff in accordance with PNNL procedures and federal regulations and the SBMS subject area, "Hazardous Materials, Packaging and Shipping" (PNNL 2009b).

\subsection{Data Reduction, Verification, and Reporting}

\subsection{Data Reduction}

Data measured during project investigations are compiled, evaluated, and documented as described in the following paragraphs. Samples and associated analyses are scheduled and tracked to assure successful sample collection. Selected data will be loaded into the 300 IFRC Project database (see Versteeg et al. 2006), as identified in the individual test plans.

Verification of analytical data is performed, as appropriate, in accordance with Appendix A of this QAPjP. Results are reviewed to assure the reliability and validity of the field and laboratory measurements based on accuracy, precision, and detection limits. Representativeness, completeness, and comparability may also be evaluated for overall quality. These parameters are evaluated through laboratory QC checks, replicate sampling and analyses, analysis of blind standards and blanks, and/or interlaboratory comparison. Acceptance criteria are established for each of these parameters in Appendix A of this QAPjP, the Environmental Sciences Laboratory QA Plan (QAP ESL, current revision), and/or in specific test plans. When parameters are outside acceptance criteria, corrective actions are taken to prevent a future occurrence and any data impacted is appropriately flagged.

When a data review identifies suspect data, those data are investigated to establish whether they reflect true conditions or an error. A Review Document Record (RDR) form is initiated in accordance with the procedure DA-3, Data Review Procedure (see PNL-MA-567) or other appropriate project-specific method. 


\subsection{Sample Data Tracking and Verification}

The process for tracking and scheduling sampling and analysis requirements, sampling field activities, chains-of-custody, and laboratory analysis is managed using a variety of electronic data management tools (see Versteeg et al. 2006). Data are received in electronic and hard copy form.

A central, web-accessible database for all samples, characterization measurements, and experimental data, which enables remote collaborative efforts, will be used. Raw data, sampling metadata, and instrument calibrations will be stored to allow an auditable, reproducible link between field measurements and finalized data. A rigorous, workflow-based process will be established to link field data to numerical predictive models to allow reproducibility. Wells and sensors will be linked to an automated data acquisition infrastructure that will utilize a dedicated wireless network. The same network will support an electronic notebook and the deployment of temporary monitoring stations.

\subsection{Sample Data and Tracking for Sediment and Other Media Samples}

Analytical data developed for sediment and other media samples will be verified by 300 Area IFRC Project staff prior to loading into the database or reported. Verification will consist of reviewing data for completeness, required QC results, chain-of-custody forms, and a case narrative that describes any issues related to the sample analyses. Verification may also include evaluating and qualifying results based on holding times, method blanks, matrix spikes, control samples, duplicates, and chemical and tracer recoveries, as appropriate to the methods used. No other verification, validation, or calculation checks will be performed. Verification will be documented on checklists to be included in the project files.

\subsection{Data Reporting}

Data measured during the 300 Area IFRC Project will be compiled, evaluated, and documented as described below. When the data review identifies suspect data, those data are investigated to establish whether they reflect true conditions or an error.

All data reported shall be traceable to the M\&TE and procedure (including procedure revision) or test plan used, and if the reported results are quantitative, a valid calibration. The analyst shall sign or initial and date the data reports unless the results printed by the instrument include identification of the analyst and date. A staff member other than the person who performed the work, and who is knowledgeable in the area being reviewed, shall review the data before results are reported.

Interpretative data, test results, and reports will be released through the information release process in accordance with the SBMS subject area, "Publishing Scientific and Technical Information" (PNNL 2007a) or in accordance with accepted protocols at participating institutions. 


\subsection{Analytical Quality Control Checks}

Analytical QC checks are performed on samples. A summary of QC check samples is outlined in Appendix A of this QAPjP, the Environmental Sciences Laboratory QA Plan (QAP ESL, current revision), and/or in specific test plans. Internal QC data are generated when analytical laboratory staff prepares QC samples to monitor the quality of their analyses.

The QC activities needed for sampling, laboratory (internal and external) and field analysis, or measurement technique will be defined in the appropriate 300 Area IFRC Project test plans. For each required QC activity, the associated method, acceptance criteria, and corrective action will be listed. Also, for the field and laboratory QC activities included, but not limited too, are the use of blanks, duplicates, matrix spikes, laboratory control samples, and surrogates in the plans. The project-specific QA Plans also identify the procedure, formulae, or references for calculating the percent recovery, bias, and precision.

\subsection{Assessments}

Assessments are performed to gather results that can be evaluated to measure the effectiveness of the quality systems and processes implemented by the 300 Area IFRC Project. Assessments will be performed periodically during the year. The following types of assessments may be used at varying frequencies during the year:

- Management self-assessment - An assessment performed by those immediately responsible for overseeing and/or performing the work to establish whether policies, practices, and procedures are adequate for assuring results needed.

- Management independent assessment - An assessment performed by an individual or group independent of the work performed to assure that policies, practices, and procedures are adequate for assuring results needed.

- Technical independent assessment - An assessment performed by an individual or group technically competent to perform the work but independent of the work being performed to assure qualitative and quantitative aspects of the work are accomplished according to documented specifications. Independent technical assessments are conducted by Field Research Executive Committee (FREC) reviews organized by ERSP.

Data quality assessments are conducted as project QC checks. The focus of data quality assessments is independent verification of reported results. Data quality is routinely evaluated through technical review. If the complexity and/or significance of the work performed warrants it, the Project Manager will direct the QA representative and/or another staff member to conduct an additional quality assessment. The assessment is documented and retained in the project records. Documentation of the above assessments, as well as any external assessments performed, is maintained as project records. The Project Manager is responsible for ensuring that any deficiencies are corrected in a timely manner. 


\subsection{Assessment Planning and Documentation}

The project management team (including Project Manager, Task Leaders, and appropriate project staff) plans assessments in consultation with the project Quality Engineer. An assessment schedule will be developed by the project Quality Engineer with Project Manager approval. Assessments may be performed by the project staff, project management, and/or the Quality Engineer in accordance with the SBMS subject area, "Assessment Management" (PNNL 2008a). The assessor plans the assessment on a Self-Assessment Planning Form (see example in Figure 9.1) where the scope of the assessment, topic, and supporting references are documented on the plan. A unique identification number is assigned to the plan and entered on an Assessment Log Sheet. The Project Manager (or delegate) approves the plan.

Results of assessments will be documented on a Self-Assessment Results form (see example in Figure 9.2). The corrective action and action owner will be documented on the assessment report. The action owners will be assigned by the Project Manager (or delegate). An action item log will be maintained by the project Quality Engineer to track and close out actions. The Project Manager will prioritize the corrective actions. The corrective actions will be verified by the project Quality Engineer. When the corrective actions have been closed, the Project Manager will sign the assessment report. The assessment plan and report will be distributed to the appropriate staff and Project Manager, and archived in project records.

\subsection{Subcontractor/Collaborator Assessments}

PNNL subcontracted work will be periodically assessed as needed to provide an oversight function or prior to contract award in accordance with the internal acquisition quality procedures. Provisions are made in the SOW for oversight assessment activities to be performed as necessary.

The results of all subcontractor/collaborator assessments (including surveillances and audits) will be made available to project and line management, individuals contacted, and the client as requested. The corrective action tracking, corrective action, and closure response will be in accordance with internal acquisition quality procedures. The official assessment report files and responses (audits and surveillances) are maintained in the PNNL Suppliers History File by the Quality Assurance Services group.

Periodic assessments of the well drilling and construction, drilling and sampling-related activities, and the Environmental Sciences Laboratory may also be performed in accordance with the above requirements.

\subsection{Preventive Equipment Maintenance}

Subcontracted organizations and collaborators will be required to implement preventive maintenance of their equipment to mitigate the possibility of down time affecting cost and schedule. This will be specified in the SOW to the respective organizations. 


\section{SELF-ASSESSMENT PLANNING FORM}

\begin{tabular}{|l|l|}
\hline Scope \& Location: (General: Maintenance, Operations) & $\begin{array}{l}\text { I.D. Number: (Assessment tracking system number or other } \\
\text { unique tracking number) }\end{array}$ \\
\hline Topic: (Describe what will be assessed) & Date: (Date planning form is prepared) \\
\hline $\begin{array}{l}\text { References: (Cite source documents for performance expectations; i.e., Regulation, Environmental Permit, DOE Order, } \\
\text { Manual, Standards Based Management System [SBMS], Requirements, Procedures and Guidelines [RPG]). }\end{array}$ \\
\hline
\end{tabular}

\section{Performance Expectations}

Criteria developed from source documents that will be applied throughout the assessment. Each criteria/expectation will have the reference enclosed in parenthesis at the end of the criteria/expectation statement (e.g., DOE Order 5480.19, SBMS, RPG). Performance expectations should be limited to six maximum to allow the assessment to remain focused. Additional planning forms can be completed to expand the scope of a particular assessment.

1.

2.

3.

4.

5.

6.

Procedure: (Perform the following as applicable for the assessment)

Review assessment planning form

- Review applicable procedure/requirements. (Include references.)

- Conduct performance tests and data validation.

- Observe the activity controlled by the procedure.

- Interview appropriate personnel about requirements and practices.

- Record observations based on comparison to plan.

- Document the results after receiving final information on the Self-Assessment Results form.

\begin{tabular}{|ll}
\hline Basics for the [ ] Planned [ ] Lessons Learned \\
Assessment: [ ] Responsive [ ] Other
\end{tabular}

Work Package Number (optional):

Assessment Requestor/Authorizing Person:

Assessor(s):

Figure 9.1. Self-Assessment Planning Form 


\section{SELF-ASSESSMENT RESULTS}

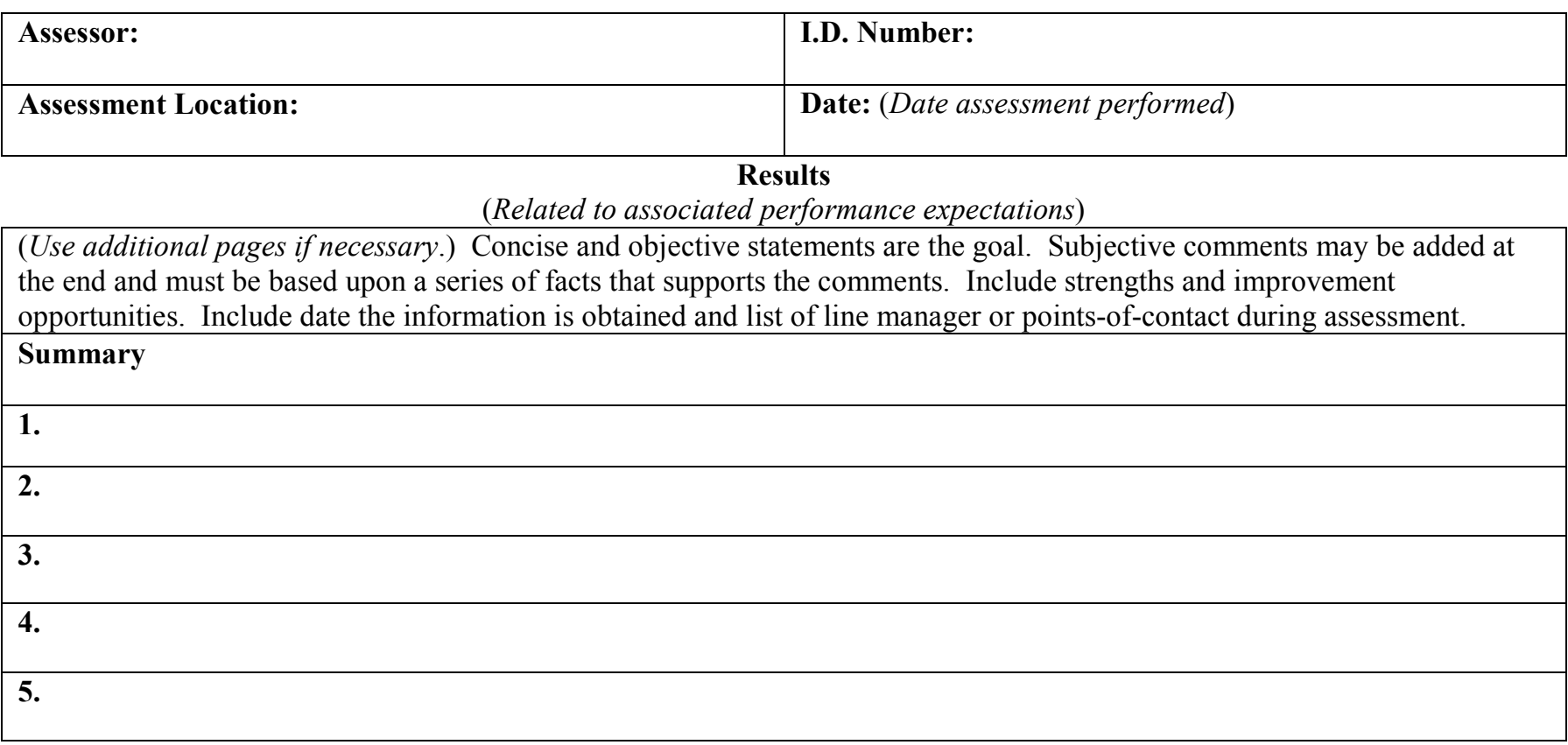

\section{Subsequent Actions}

(Related to associated results)

\begin{tabular}{|l|l|l|}
\hline \multicolumn{1}{|c|}{ Assigned Action } & \multicolumn{1}{|c|}{ Action Owner } & Due Date \\
\hline 1. & & \\
\hline 2. & & \\
\hline 3. & & Date: \\
\hline 4. & \\
\hline Actions Assigned By: & \\
\hline $\begin{array}{l}\text { Completion (To be signed by Lead Assessor when assessment is completed.) } \\
\text { Signature: } \\
\text { Date: }\end{array}$ \\
$\begin{array}{l}\text { Completion (To be signed by Manager when assessment is completed and all actions have been entered into ATS) } \\
\text { Signature: } \\
\text { Date: }\end{array}$
\end{tabular}

Figure 9.2. Self-Assessment Results 


\subsection{Specific Routine Procedures Used to Assess Data Precision, Accuracy, and Completeness}

The evaluation of laboratory precision, accuracy, and completeness is accomplished during the verification process performed upon receipt of data (see Section 7.0 of this QAPjP).

\subsection{Corrective Action}

\subsection{Project Corrective Actions Resulting from Assessments}

As part of the continuous improvement processes initiated by the project management team, assessments will be tracked and improvement actions identified and prioritized. The "Assessment Tracking System (ATS)" is the process used by this project for tracking and managing assessments, including determining conditions and the development of actions. ATS supports the identification, control, and correction of items, services, and processes that do not meet established requirements. The SBMS subject area, "Assessment Management" (PNNL 2008a) documents this corrective action management process for handling and documenting events and assessments, including those which must be tracked in ATS (such as formal project reviews or audits performed by the client or their representative; management-initiated assessments; etc.). If immediate corrective action is required, the quality problem will be directly entered into the ATS and actions taken as specified in Section 12.2.

\subsection{Unplanned Deviations}

Corrective actions must be initiated by the Project Manager or cognizant Task Manager when unplanned deviations from procedural, contractual, regulatory requirements, or construction specifications occur. These deviations will be documented by documenting the quality problem information directly into the ATS in accordance with the SBMS subject area, "Assessment Management" (PNNL 2008a). The assessment must describe the problem, the cause of the deviation, the impact of the problem, and corrective actions needed to remedy the immediate problem and to prevent recurrence.

Subcontractors/collaborators will be required to have systems in place to identify, correct, and prevent recurrence of contractual, procedural, or regulatory requirement(s) deviations, and to notify the PNNL point-of-contact specified when such an event occurs. These requirements will be passed on in the subcontractor SOWs.

\subsection{Planned Deviations}

Planned deviations from procedure, documented (including justification) and approved by the Project Manager or Task Manager in advance, do not constitute a deficiency and do not require generation of an assessment item. Documentation may consist of a hard copy e-mail or memo to the Project Manager or Task Leader. This documentation must include either an approval signature if on a memo, or electronic approval via reply to the e-mail indicating such approval. 


\subsection{Measuring and Test Equipment Calibration Discrepancies}

Subcontractors will be required to maintain a system for identifying calibration discrepancies and tracing data or samples that may have been affected. Subcontractors will be required, via their SOW, to notify the PNNL point-of-contact as soon as possible when such an incident occurs. PNNL may perform periodic assessments to assess the effectiveness of subcontractor procedures and processes for calibration control.

Project staff must investigate instruments or equipment found to be operating outside acceptable operating ranges (as specified in the applicable technical procedure or manufacturer's instructions) and issues must be addressed in accordance with the SBMS subject area, "Assessment Management" (PNNL 2008a). When as-found data on an instrument's calibration report was found to be "Out of Tolerance" during the review and acceptance process of the contract-supplier documents submitted in response to quality requirements, an Out-of-Tolerance Notification will be generated using the ATS in accordance with the SBMS subject area, "Assessment Management" (PNNL 2008a). The project staff must then determine if there was any impact on data. When it is determined from calibration verification that Category 1 or 2 M\&TE is out of tolerance, staff should proceed with the evaluation to determine impact on data and document the results with appropriate justification.

\subsection{Quality Assurance Reports to Management}

Quality activities such as project improvement efforts, significant deficiencies identified, associated corrective actions, and summary of assessment results will be reported to the Project Manager. Major quality problems are reported to the Project Manager. Surveillance plans and results of the surveillances are provided to the Project Manager and Task Manager after a surveillance event.

Quality-related problems identified by project personnel must be reported to the Project Manager immediately for resolution. Any problems involving data quality, sample integrity, or test measurements will be thoroughly documented and communicated to the appropriate Task Manager and Project Manager for resolution.

Significant quality-related problems that may affect customer satisfaction shall be communicated to the cognizant Product Line Manager by the Project Manager.

\subsection{Records}

\subsection{Records Control}

The SBMS definitions of project records and record material apply to this project. As stated in the SBMS subject area, "Records Management" (PNNL 2008f), project records are any recorded information relating to a specific research project. Record material includes information, regardless of its media (e.g., hard copy, electronic, microfilm), created or received in connection with PNWD business or research activities that document research and administrative functions, policies, decisions, procedures, operations, or other activities, and which is preserved for its value. 
Note: E-mail that is record material must be printed out and maintained as the record copy unless the e-mail is saved in the PNNL Total Records Information Management (TRIM) System.

Record material that is not stored in field notebooks or LRBs (see Section 19.5 of this QAPjP) or is not electronic data gathered from sensors or instruments in the field and/or lab (see Section 14.3) such as project-specific field data forms, shall be scanned and managed as portable document format (PDF) files in accordance with Section 14.3. Record material shall be scanned and archived at least quarterly or more often — such as weekly or monthly — if the accumulation of material is significant and inadvertent damage or loss would cause irreparable damage to the project.

Records that document the sampling subcontractor activities, analytical results, verification and compliance checks, quarterly and annual reports, test plans and associated results, groundwater monitoring plans, and assessment reports will be maintained as project records. Individual monitoring plans and work plans may identify other records requirements. Project records will be legible, identifiable, and maintained in accordance with the SBMS subject area, "Records Management" (PNNL 2008f). Test results documented in LRBs will be reviewed semi-annually by a technically qualified individual who did not perform the work. The reviewer will verify that there is sufficient detail to retrace the investigation and confirm the results.

The project records specialist prepares and submits a File Plan (See File Plan Form) for review and approval by the records management representative, Project Manager, and Quality Engineer. The Records Custodian reviews and updates the File Plan Form annually at a minimum, or when a major change to the program occurs.

\subsection{Records Transfer to Storage}

On an annual basis, the Records Custodian will transfer to storage inactive records as identified by the project staff as not required for day-to-day operations. Sampling and analysis plans, assessments, and special project correspondences will be maintained by the project until the completion of the activity or project. The project records specialists generates the internal form (e.g., Records Storage Form). The records management representative will sign the Records Storage Form as acknowledging receipt of the records and return a copy of this form to the records custodian. The Records Storage Form is then placed in project records.

Within 90 days of project completion or termination, records shall be transferred to storage and/or the client. The project records specialist completes the appropriate internal form (e.g., Records Storage Form). The records management representative will sign the Records Storage Form as acknowledging receipt of the records and return a copy of this form to the records custodian. The Records Storage Form is then placed in project records.

\subsection{Electronic Data/Records Management}

Electronic data gathered from sensors or instruments in the field and/or lab will be maintained and managed appropriately to allow for reproducible results. Electronic data that are directly delivered and/or used in analyses that are delivered to the customer will be maintained as project records, in accordance with the requirements of the SBMS subject area, "Records Management" (PNNL 2008f). 
Electronic data produced by instrumentation or sensors are usually stored on that instrument and are only usable by the system itself. It is necessary for the electronic data to be transferred, without error, to a form that can be used by a variety of software applications. An example would be to transfer an ASCII file into an Excel $^{\circledR}$ file. To ensure the data-transfer process has occurred in an acceptable manner, a review of a representative sample, of sufficient data points to provide confidence that the data have been transferred properly, shall occur. The review method used and results obtained shall be documented and retained as project records in the LRB, in accordance with Section 19.5 of this plan. For data retrieval, the staff member shall record the use of the data on the media used to store the raw data and in the project records. The staff member shall ensure that unauthorized modifications are not made to the data during its use. The method of control shall be documented in the project records by the staff member. The staff member shall ensure that a backup of the data is maintained in the project records. The use of the data in software applications shall be documented, along with the software application name and version number.

Electronic data shall be archived and saved as project records based on the project's record-retention period. When the project records are required to be maintained for a minimum of 10 years, after the close of the project, saving the raw electronic data files to a CD/DVD is sufficient. When the project's record retention requirements are longer than 10 years, the raw data files should be saved either to magnetic media (TRIM, tape) or optical media (CD, DVD). The TRIM system is one option for storing raw data files and is approved for projects that have a permanent retention period.

Backup and archive processes shall be followed for maintaining the data during the life of the project. Electronic data backups shall be performed every night, in accordance with the requirements identified by the PNNL IT Computing Services InfoSource website. The computer backup procedures identified on the PNNL Infosource website for "Data Backup Options" shall be followed based on the type of computer or server on which the data are stored. The data backup process is identified in the following sections.

\subsubsection{Workstations}

PNNL staff members are responsible for ensuring the data on the computers they use are backed up regularly. There are three (3) options for backing up these data:

1. The staff member can sign up for one of the PNNL workstation backup and restore (WBR) services: WBR Connected DataProtector for Windows ${ }^{\circledR}, \underline{\text { WBR Mac for Macintosh }}{ }^{\circledR}$, or WBR Networker for all other systems ${ }^{1,2}$. WBR is free to each PNNL staff member for one workstation. Additional backup subscriptions are available for a small monthly fee. (See the WBR website for restore instructions.) The maximum backup size is 100 gigabytes (GB) for Windows workstations.

2. A network shared folder may be used to store files on a PNNL network file server. Network shared folders are backed up nightly. To retrieve files from a backup, request a file restore by calling the PNNL Help Desk at 375-6789 or send an e-mail. They will need the complete name of the shared folder (e.g., $\backslash$ pnl10 \projects) and the name and date of the file or directory that needs to be restored.

3. Manually copy files to floppy disks, CDs, or DVDs. Most computers purchased through the Managed Hardware Program come with large-capacity floppy drives, CD-RW drives, and/or DVD

\footnotetext{
${ }^{1}$ Windows is a registered trademark of Microsoft Corporation.

${ }^{2}$ Macintosh is a registered trademark of Apple, Inc.
} 
drives. A CD can hold 600 megabytes or more; DVDs 4.7 GB. Either of these methods is suitable for backing up important data files, but not recommended for backing up the entire system.

\subsubsection{Servers}

The data backup options for servers include:

1. The WBR service. For a small monthly fee, WBR performs a full backup of all the project's programs and data. (See the WBR website for restore instructions.)

2. Backing up to Zip disks or to a tape drive connected to the server. If a tape drive connected to the project server is used, refer to the manufacturer's instructions for establishing backup schedules and performing restores.

Data archiving shall occur at least every 2 weeks. It is recommended archiving occur at least once a week. The electronic data shall be archived to a CD/DVD and kept in the project working files until the electronic data are no longer being used; at that point, the electronic data shall be moved to TRIM when longer storage retention is required by the records requirements.

\subsection{Procurement Control}

To ensure that procured items and services satisfy the technical and quality requirements of the user and/or client, all procurements shall be obtained in accordance with the applicable SBMS subject areas, "Procurement" (PNNL 2008b), "Purchase Orders/Subcontracts (PNNL 2008c)," "Purchasing Cards (P-Cards)" (PNNL 2008d), "Purchasing Through the Business-to-Business Program" (PNNL 2008e), and "Suspect/Counterfeit Items and Misrepresented Products, Reporting and Handling" (PNNL 2006c). In addition, electrical equipment purchased for use on the project shall also be obtained in accordance with the SBMS subject area, "Electrical Equipment: Designing, Purchasing, and Installing" (PNNL 2009a).

Quality-affecting materials (e.g., calibration standards, chemicals), equipment (e.g., instruments, geophysical measurement equipment), or services (e.g., calibration, analytical services, geophysical measurements, or other subcontracts for technical services) will be obtained in accordance with the SBMS subject area, "Purchase Orders/Subcontracts" (PNNL 2008c). For this project, the majority of procurements will result in purchases of services such as drilling, sampling, and analysis. All procurements will be obtained in accordance with the SBMS subject area, "Purchase Orders/ Subcontracts" (PNNL 2008c). SOWs for purchasing services shall be reviewed and signed by the project Quality Engineer to assure consistency of QA requirements specified to subcontractors with project quality standards in this QAPjP.

A QA representative shall approve all procurements containing QA requirements. Procurement documents shall specify technical and QA requirements, including documentation to be furnished by the supplier. Submittals from suppliers shall be reviewed to verify their compliance with the procurement document technical and QA requirements, in accordance with implementing procedure AQP-06, Review of Supplier/Subcontractor Submitted Documents. This review is performed by a QA representative.

Project staff members shall verify that items and services requested are acceptable when received in accordance with the above SBMS subject areas. 


\subsection{Geophysical Equipment}

Procured instruments, components, and equipment (including rental equipment) used for geophysical work shall meet applicable standards such as Underwriter's Laboratory, American National Standards Institute, or Institute of Electrical and Electronics Engineers and, whenever possible, should be listed by a nationally recognized testing laboratory. Upon arrival on site, all electrical equipment and instruments shall be inspected by a qualified electrical worker and staff with knowledge of the equipment. The equipment shall be powered for testing and the qualified electrical worker shall follow the appropriate diagnostics and testing procedure in the SBMS subject area, "Electrical Equipment: Designing, Purchasing, and Installing" (PNNL 2009a). The results of this inspection shall be documented on the Electrical Safety Design Criteria Checklist and forwarded to the PNNL Electrical Safety Engineer for approval prior to acceptance and use of the equipment in the field. Note that the examination process and documentation described in the preceding paragraph is not required for minor components such as resistors, diodes, circuit boards, or similar electronic parts.

\subsection{Groundwater and/or Sediment Analytical Measurements}

If the groundwater or sediment analysis will be conducted by subcontractors or collaborators on the project, requirements will be specified in the SOW or Letter of Instruction (LOI) as applicable, and shall be used to obtain the analytical services. The LOI is the mechanism to be used for work requests to other Hanford Site contractors. An LOI or SOW must accompany each purchase order. A review must be performed by the Quality Engineer during the planning stages and preparation of the SOW/LOI. The SOW must define the data quality and any additional project requirements associated with the service requested. The data quality requirements should include a description of the QC samples for each analysis for determining the level of possible contamination from preparation and analysis. The project requirements should include information on the following:

- analysis method

- calibration standards traceable to the National Institute of Standards and Technology

- sample turnaround time and reporting requirements

- disposal requirements for remaining sample material and the waste from the process.

The LOI/SOW will pass on the requirements of the EPA Requirements for Quality Assurance Project Plans $(Q A / R-5)(E P A / 240 / B-01 / 003)$ and HASQARD (DOE/RL-96-68) to the analyst.

\subsection{Other Hanford Contractor Services}

Other Hanford contractor services (e.g., well drilling and construction) will be obtained using the procurement process. An electronic requisition will be generated by project staff accompanied by a work authorization document (LOI or SOW). The work authorization document will describe the requirements for the requested services. The SOW will pass on the requirements of the EPA Requirements for Quality Assurance Project Plans (QA/R-5) (EPA/240/B-01/003) and HASQARD (DOE/RL-96-68) to the subcontractor. A review must be performed by the Quality Engineer during the planning stages and preparation of the SOW/LOI. 


\subsection{Staff Training}

Staff performing activities affecting quality shall be issued documented training assignments, including applicable project administrative and technical procedures and this plan.

1. Project manager and staff members will assess project-specific training needs. The assessment will include evaluating cumulative training records of the staff.

2. Project manager will assign reading and/or briefings of procedures as needed. If training is assessed and the need for formalized training is identified, the staff member will be scheduled to attend a formal training class.

3. Training will be documented on either a Briefing Document, an individual On-the-Job Training (OJT) form; a Reading Assignment Documentation form; or a Group OJT or Reading Assignment Documentation form. These forms are available internally to PNNL staff. Documentation shall be sent to the PNNL Laboratory Training Coordinator for input into the training database. The training database will contain the record copy of project staff training.

Project staff shall be comprised of personnel who are knowledgeable and possess adequate technical, managerial, or professional skills to perform all assigned tasks. The Project Manager will identify any additional specific project-related processes that will require project staff training and qualification, and who will be responsible for assuring the project-specific training will be developed, delivered, and changes managed in accordance with the SBMS subject area, "Training Design, Development, Implementation and Evaluation" (PNNL 2002). The project shall maintain training documentation for project-required coursework or OJT training taken by staff that is not capable of being tracked in the Laboratory's training database in accordance with the SBMS subject area, "Training and Qualification for Staff and Non-Staff"' (PNNL 2009c).

The Project Manager, or delegate, shall inform the immediate manager of project staff of the requirement to take project-required training and assure that the training has been completed prior to project staff conducting work that requires the training. The immediate manager of project staff, or their delegate, shall record the need for identified project-required training and assuring training (and retraining for changes) records (for both Laboratory-level and project-specific training) will be maintained in accordance with the SBMS subject area, "Training and Qualification for Staff and Non-Staff" (PNNL 2009c).

The development of software products that require complex or unfamiliar interactions with users and operators should include a comprehensive plan for training. The training plan should include the following:

a. A description of the populations to be trained, the training objectives for each population, and the content to be covered in the training.

b. An estimate of the amount of resources necessary for training development, delivery, and time expenditures.

c. Procedures for evaluating the effectiveness of the training and for making modi fications to the training. 
The Project Manager has identified the following project-specific training requirements for project core team members:

- PMP

- QAPjP

- Field Site Management Plan

- Health and Safety Plan

- Communications and Community Interaction Plan.

The project shall maintain training documentation for project-required coursework, or OJT training taken by staff, which is not capable of being tracked in the Laboratory's training database in accordance with the SBMS subject area, "Training and Qualification for Staff and Non-Staff" (PNNL 2009c).

\subsection{Software Control}

For the purpose of design activities covered by the activities identified in the plan, "software" is defined as computer programs, including computer programs embedded in firmware (see the SBMS subject area, "Software" [PNNL 2007b]). Excluded is software that is an integral part of firmware or equipment, where all software maintenance is performed by the vendor and the software is verified as an integral part of the system (e.g., calibration with known standard materials). The software clause (QA-197b) will be integrated in any SOWs, at a minimum, and possibly with additional clarification, when requested by the vendor.

All software applications used for the projects under this plan will be reviewed and graded. The grading process for software will be recorded and copies for each application will be maintained as project records for each project that falls under this plan. Software applications that apply to this plan do not have the potential to be identified as safety software and will not be identified as such; therefore, these applications do not need to follow the "Safety Software" (PNNL 2008h) requirements, as identified in SBMS.

\subsection{Software and Software Applications}

Software applications identified for the project in this plan will perform the work activities identified below that pertain to custom developed, configurable, and acquired/legacy software.

\subsubsection{Minimum Documentation Requirements}

To ensure that implementation of the software satisfies requirements, the following documentation is required as a minimum for all software applications. The rigor of the documentation will be determined by project management based on a graded approach of the software application.

Grading of the requirements will be based on the risk associated with the failure of the intended use of the software. There are three categories identified with the grading of the software requirements: 
Detailed, Functional, or Summary level. The grading and category level of each application under this plan will be identified in the appropriate documentation.

a. Software Requirements Specification (SRS)

b. Software Design Description (SDD)

c. Verification and Validation Plan (VVP)

d. Verification and Validation Report (VVR)

e. Configuration Management Plan (CMP)

1. A problem reporting and corrective action tracking system will be identified with the CMP documentation.

2. Data management process will also be identified, when applicable.

f. Procurement contractual documentation, when applicable

\subsubsection{Software Requirements Specification}

The Software Requirements Specification (SRS) shall clearly and precisely describe each of the essential requirements (functions, performances, design constraints, and attributes) of the software and the external interfaces. Each requirement shall be defined such that its achievement is capable of being objectively verified and validated by a prescribed method (e.g., inspection, analysis, demonstration, or test). The SRS will be developed with less rigor when the software being used is configurable, acquired but slightly customizable, or legacy software.

The SRS is subject to the Software Requirements Review (SRR) when needed and will be documented. The SRS is subject to a SRR by the client when the software is the deliverable and not just used to provide analysis or results for a clients deliverable. Client acceptance of the requirements will be documented when required.

\subsubsection{Software Design Description}

The software design description (SDD) shall depict how the software will be structured to satisfy the requirements in the SRS. The SDD shall describe the components and subcomponents of the software design, including databases and internal interfaces. The SDD is a technical description of how the software will meet the requirements established in the SDD. Its most important function is to describe a decomposition of the whole system into components (subsystems, segments, etc.). In addition, it should document the rationale for the more important design decisions to facilitate the understanding of the system structure.

The SDD will describe major system features such as databases, diagnostics, external and internal interfaces, as well as the overall design structure. It involves descriptions of the operating environment, timing, system throughput, tables, sizing, centralized or distributed processing, extent of parallelism, client/server, reusable objects library, program design language (PDL), prototypes, modeling, simulation, etc. The SDD will also describe any input and output data that may be required. 
The SDD will be baselined after each significant review. A new version containing a more detailed design description is developed for each subsequent review when new enhancements or defect fixes are incorporated.

The SDD will be developed with less rigor when the software being used is configurable, acquired but slightly customizable, or legacy software. The SDD is used to help design new enhancements or defect fixes when the design involves custom-developed code. Flow charts and/or flow diagrams can aid in the development and documentation of the design, and when custom development is minimal, can be used as the software design.

The software design description is subject to the Software Design Review (SDR) when needed, and will be documented.

\subsubsection{Verification and Validation Plan}

The Verification and Validation Plan (VVP) shall identify and describe the methods (e.g., inspection, analysis, demonstration, or test) to be used:

1. To verify the following:

- Requirements in the SRS have been approved by an appropriate authority.

- Requirements in the SRS are implemented in the design expressed in the SDD.

- Design expressed in the SDD is implemented in the code.

2. To validate that the code, when executed, complies with the requirements expressed in the SRS.

The VVP describes the overall plan for the verification and validation of the software/modeling and will be produced and reviewed incrementally for software applications. The tasks, methods, and criteria for verification and validation will be described in the appropriate VVP for each application.

The VVP will be used for documentation of the testing standards and practices as they are de fined in each application VVP. The VVP will explain the validation testing scope to ensure the baseline requirements are met, explain the stages of development that will require customer review, and the extent of the verification that will precede such a review.

The VVP will specify minimum test documentation requirements for each test performed. Additionally, a section of the VVP will identify a verification matrix where the requirements are listed with their corresponding test identified in the VPP. A matrix will be maintained during the life of the software and will be used to verify all the requirements have been met, identified, and tested.

VVP contents will be evaluated at the Verification and Validation Plan Review (V\&VPR) prior to testing. A V\&VPR will be conducted when significant changes are made to the baseline. The V\&VPR will be used to identify all changes to be tested and to pass on pertinent information to the appropriate testing staff. 


\subsubsection{Verification and Validation Report}

The Verification and Validation Report (VVR) shall describe the results of the execution of the VVP. The VVR summarizes the observed status of the software as a result of the execution of the VVP. The VVR should include the following information:

a. Summary of all life cycle verification and validation tasks.

b. Summary of task results.

c. Summary of anomalies and resolutions.

d. Assessment of overall software quality.

e. Summary from the verification matrix.

f. Recommendations such as whether the software is, or is not, ready for operational use.

The report may be a full report or a summary (depending upon the grading of the software).

\subsubsection{User Documentation}

User documentation will be developed for applications where the code is part of the deliverable.

\subsubsection{Configuration Management Plan}

The Configuration Management Plan (CMP) shall document methods to be used for identifying software items, controlling and implementing changes, and recording and reporting change implementation status. The CMP should describe the tasks, methodology, and tools required to assure that adequate configuration management procedures and controls are documented and are being correctly implemented. If the CMP is not a standalone document, and is included in the QAPjP or PMP, it is not necessary that the Quality Assurance organizational element prepare the CMP; however, it is essential that one exist for each project or set of applications under each project. The process of data management should also be identified in the CMP, when data input is used to produce results and the application is not the deliverable.

The CMP should describe the methods to be used for the following:

a. Identifying all the configuration items (software modules, documents, data, etc).

b. Controlling and implementing changes.

c. Recording and reporting change and problem reports implementation status.

d. Conducting configuration audits, when appropriate.

e. Identifying review and approval cycles, as well as signature authority.

f. Identifying the personnel responsible for maintaining the baselines and distributing the CMP.

The CMP shall contain the information identified in the SBMS subject area, "Software" (PNNL 2007b) for Software Maintenance. A summary of the requirements for maintaining software are as follows: 
- Track defects and requests for changes

- Plan and approve software updates and changes

- Modify software and test

- Maintain source code and documentation.

\subsubsection{Other Documentation}

Other specific project plans for each project under this plan may include the following:

- PMP

- QaPjP

- Security Plan.

PMP. The PMP can be used as the highest-level planning document governing a project, or could be subordinate within a larger set of plans. The PMP should identify all technical and managerial activities associated with the project. The PMP should specify the items, which should be reviewed and assessed by the project Quality Engineer. The PMP should identify the risks associated with the use of the software if a failure was to occur and that the steps are to mitigate the risks identified.

Security Plan. A Security Plan is only required if any of the software tools are going to be put out on internal PNNL websites.

Risk Identification and Mitigation. Specific risk and hazards that pertain to the maintenance, development, and/or use of software will be identified and documented in the project records associated with the task that required the software. The planned means to manage and mitigate the risks and hazards will also be documented. An example of a possible risk and management of that risk is identified below.

RISK EXAMPLE: The primary risk posed by use of this software is that a mistake in the software design or implementation could result in the calculation of an erroneous result, resulting in one or more of the following undesirable outcomes:

- For projects in progress, adverse impacts to project budget and schedule as corrections are made and calculations repeated to correct the mistake.

- For completed projects, invalid regulatory products that rely on the calculations performed with the software.

- Damage to the reputation of the Laboratory.

RISK MANAGEMENT EXAMPLE: The primary means to minimize the risk of software errors of consequence are as follows:

- Adherence to the processes defined in this QAPjP.

- Development and execution of a Software Test Plan

- Timely identification, response, and communication to affected parties regarding software errors and anomalies discovered by PNNL staff involved in use, maintenance, and development of the software. 


\subsection{Software Use in Analysis}

This section applies to the use of software of any kind by this project to conduct analyses delivered, or in support of a deliverable, to the customer. Included in this definition are data analysis tools including spreadsheets and statistical analysis software, databases, modeling, and simulation tools. Excluded are software productivity tools, such as word processors and spreadsheets, when no automated calculations, macros, or scripts are used. The activities under this plan shall conduct work in accordance with requirements for the control of software used in analyses as defined in the SBMS subject area, "Software" (PNNL 2007b) based on the risk associated with the use of the software. Using software to conduct analysis requires the following:

- Risks are identified.

- Reviewers are identified to review the results and implementation of the software.

- Analysis is planned.

- Basis for the validation/review is documented.

- Analysis is conducted.

- Results are validated by the identified independent reviewer and review results are documented.

\subsection{Utility Calculations}

The purpose of this section is to define a uniform method for documenting the quality controls in place when using software packages (e.g., Microsoft Excel ${ }^{\circledR}$, Mathematica ${ }^{\circledR}$, Matlab ${ }^{\circledR}$, Mathcad ${ }^{\circledR}$, etc. known as Utility Calculations) for calculations that are a significant part of a client deliverable, but not classified as safety software. Excel or other Utility Calculation analyses that are not used for a significant part of a client deliverable, or are only used to double check data, are exempt from these instructions. These instructions apply to the use of scripts and/or macros, within Excel, as well as Excel basic calculations. Portions of this project that have been identified as containing safety software must follow the Utility Calculations Guidance identified in the SBMS subject area, "Safety Software" (PNNL 2008h). For additional information, refer to the SBMS subject area, "Software," "Section 11 - Using Software to Conduct Analysis" (PNNL 2007b).

NOTE: Excel is used as the example in these instructions; however, the process is the same for all other Utility Calculations.

These requirements and instructions apply to Project Managers and staff who will use Excel to conduct analysis to be delivered to the client, or to conduct analyses in support of a deliverable to the client. The process shall be implemented as follows:

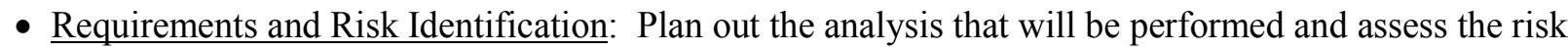
associated with software failure. Document the associated risk and the analysis to be performed (this could be one paragraph in a Microsoft Word ${ }^{\circledR}$ document or on another tab in the Excel spreadsheet itself) ${ }^{1}$. (See risk examples in Table 17.1.)

\footnotetext{
${ }^{1}$ Microsoft Word is a registered trademark of the Microsoft Corporation.
} 
- Design and Validation Planning: Prepare and document how the Excel file will be validated/reviewed and tested by an independent technical reviewer. Identify and document who will perform the independent technical review. (Identify the problem that needs to be solved and what actual calculations are being performed to solve the problem. This information will be useful for the independent technical reviewer. This could be one paragraph in a Word document or on another tab in the Excel spreadsheet itself.)

- Implementation: Conduct the analysis using the Excel spreadsheet with the appropriate calculations based on the planning previously performed. (If the implementation of the analysis has changed, go back and update the risk associated with the analysis and the documentation to be used for the validation, if applicable)

Table 17.1. Software Risk Management Example

\begin{tabular}{|c|c|c|c|c|c|}
\hline Identified Risk & $\begin{array}{c}\text { Overall Risk } \\
\text { to Project }\end{array}$ & Preventive Action & $\begin{array}{c}\text { Contingency } \\
\text { Action }\end{array}$ & Trigger & Owner \\
\hline $\begin{array}{l}\text { Change in } \\
\text { requirements after } \\
\text { start of design/ } \\
\text { development }\end{array}$ & Medium & $\begin{array}{l}\text { Have customer approve } \\
\text { requirements before } \\
\text { design/ development, } \\
\text { flexible design and CM } \\
\text { process }\end{array}$ & $\begin{array}{l}\text { Changes affect } \\
\text { either schedule or } \\
\text { resource allocation }\end{array}$ & $\begin{array}{l}\text { Customer } \\
\text { request }\end{array}$ & $\begin{array}{l}\text { Battelle / } \\
\text { Customer }\end{array}$ \\
\hline $\begin{array}{l}\text { Incomplete input } \\
\text { data }\end{array}$ & High & $\begin{array}{l}\text { Identify appropriate } \\
\text { sources of validation } \\
\text { data }\end{array}$ & $\begin{array}{l}\text { Manual updates to } \\
\text { input tables are } \\
\text { tracked through the } \\
\text { change control } \\
\text { process }\end{array}$ & $\begin{array}{l}\text { Appropriate } \\
\text { input tables not } \\
\text { available }\end{array}$ & $\begin{array}{l}\text { Battelle / } \\
\text { Customer }\end{array}$ \\
\hline $\begin{array}{l}\text { Change in project } \\
\text { budget or/or } \\
\text { schedule }\end{array}$ & Low & $\begin{array}{l}\text { Define and implement } \\
\text { new process }\end{array}$ & $\begin{array}{l}\text { Continue current } \\
\text { process }\end{array}$ & $\begin{array}{l}\text { Coordination } \\
\text { issues with } \\
\text { customer }\end{array}$ & $\begin{array}{l}\text { Battelle / } \\
\text { Customer }\end{array}$ \\
\hline $\begin{array}{l}\text { Invalid regulatory } \\
\text { products that rely } \\
\text { on calculations } \\
\text { performed with } \\
\text { this software }\end{array}$ & Low & $\begin{array}{l}\text { Develop and execute a } \\
\text { Software Test Plan to } \\
\text { cover all calculations in } \\
\text { the system }\end{array}$ & $\begin{array}{l}\text { Identify critical } \\
\text { calculations and } \\
\text { test based on use of } \\
\text { the system }\end{array}$ & $\begin{array}{l}\text { Software codes } \\
\text { are required to } \\
\text { be reviewed with } \\
\text { a customer } \\
\text { QA/QC process }\end{array}$ & Customer \\
\hline
\end{tabular}

Note: Overall risk rating is medium.

- Verification: Review/verify the results of the analysis. Review the results produced from the analysis. Determine if the analysis and results support the problem that needs to be solved. Document the verification/review step. (Documenting this step can be done with one paragraph in a Word document or on another tab in the Excel spreadsheet itself of what was reviewed, and identify if the outcome was acceptable or if additional work needs to be done.)

- Validation: Conduct independent review of results and validation. Provide the identified independent technical reviewer the Excel spreadsheet and Word document, if applicable. (The reviewer needs to have all the information regarding the requirements, risk, design, and review expectations to perform the review.) 
- Independent Technical Review: Reviewer performs the review, per the instructions provided, and documents any additional checks performed on the file that extended outside the original scope of the review and the method used to perform the review of the results. The reviewer documents the review outcome. (The documentation can be a paragraph in a Word document or on another tab in the Excel spreadsheet itself.)

- Results shall be determined based on using an alternate method to perform the analysis. Typical alternate methods include literature review, empirical data, hand-calculations, or executing the analysis on a comparable but different tool.

- Documentation: Print the Excel spreadsheet with the analysis/results and attach the Word document or the tab in the Excel spreadsheet itself that contains the identified requirements, risk, design, validation steps, verification, and independent technical review steps and results. Have the independent technical reviewer sign the document, and the verifier sign the verification step. Archive this signed document in project records.

\subsection{Collaborator Specific Software Requirements}

The following subsections apply to researchers participating in the 300 Area IFRC Project who are not PNNL employees or are engaged in software or computer model development at PNNL or the Hanford Site. Because of the unique nature of PNNL/collaborator relationships in this project, and the fact that PNNL has not imposed SBMS requirements on offsite contractors, it will be necessary for collaborators to demonstrate how they will comply with applicable software requirements.

\subsubsection{Idaho National Laboratory}

The Idaho National Laboratory (INL) shall conduct work under this project in accordance with a QAPjP based on quality assurance requirements in DOE Order 414.1C, Quality Assurance, for all software development and use of existing software activities in support of this project.

INL researchers shall establish and perform work processes for developing and using safety software, as defined in DOE Order 414.1C. Work processes involving safety software must be developed and implemented using national or international consensus standards and shall include the following elements:

- Facility design authority involvement in the identification of software requirements specification, acquisition, design, development, verification and validation (including inspection and testing), configuration management, maintenance, and retirement.

- Identify, document, and maintain a safety software inventory.

- Establish grading levels for safety software. Document those grading levels in the Quality Assurance Manual.

- Using the grading levels established and approved above, select and implement applicable software quality assurance work activities from the list below to ensure that safety software performs its intended functions. The American Society of Mechanical Engineers standard NQA-1-2000 shall be used to implement these work activities. 
- Software project management and quality planning

- Software risk management

- Software configuration management

- Procurement and supplier management

- Software requirements and identification and management

- Software design and implementation

- Software safety

- Verification and validation

- Problem reporting and corrective action

- Training of personnel in the design, development, use, and evaluation of safety software.

- These requirements shall be passed to any subcontractors performing work regarding safety software development or use in support of this contract.

A pre-award evaluation shall be conducted of INL's software development capability and/or usage practices to confirm that it complies with DOE Order 414.1C. Additional audits/assessments of the software development process may be conducted during the project.

\subsubsection{Los Alamos National Laboratory and University Collaborator Computer Modeling Activities}

For all software used in preparation of the deliverables for this project, Los Alamos National Laboratory, the University of California at Berkeley, and the University of Alabama shall conduct work under their subcontracts in accordance with the following (this includes existing software applications and/or models and use of spreadsheets for complex calculations):

- Verify that the software is applicable to the problem for which it is being used to solve. Document the software used and rational for choosing the application when reporting data calculations, from a software application, which is part of any deliverable under this contract.

- Maintain configuration management of the software used. Identify and document what software is being used for data calculations, what version of the software was used, and what operating system the software was running on when data and/or calculations were produced. This applies when reporting data from a software application that will be part of the deliverables for this contract.

- Validate that the software performs correctly over the range of problems that will be analyzed in performance of the contract.

- Define and document test cases or items to be tested based on what parts of the application are being used. (Identify and document option settings of models used, if applicable)

- Identify and document, if applicable, values required for input.

- Identify and document acceptance criteria defining the degree of variability that is acceptable between the results of the analysis and results from an alternate method. This could range from exact duplication of results, to several significant figures, to order of magnitude agreement 
depending on expectations. Acceptable alternate methods are literature review, empirical data, hand-calculations, and/or executing the scenarios on a comparable but different tool. Alternate methods used for acceptance criteria shall be referenced and sources cited.

- Determine method to manage multiple sets of results in the event that the analyses or a portion of the analyses needs to be reproduced or re-executed, when applicable.

- If more than one version of the software will be used to conduct the analyses, determine and document methods for controlling the versions and confirm the results are consistent across all versions used.

- Conduct the validation according to the cases and items identified. Document the results of the validation, who performed the validation, and when the validation was performed.

- Resolve any bugs and/or problems with the implementation of the software application and revalidate, when necessary, until the results are acceptable. Document and report any outstanding bugs or problems found during validation, which will not be resolved, prior to submitting deliverables.

- An independent reviewer shall verify that the results are accurate either through review or alternate methods of performing the calculations or analysis. Identify and document the independent reviewer, what method was used to verify the results, and if the results and validation of the software application are acceptable.

Requests for and reviews of the documentation in support of the software use may be conducted, by PNNL, any time during the project.

\subsection{Nonconformances and Deficiencies}

Procured materials found to be in nonconformance with specifications or where the quality of an activity is found not to be in compliance, the quality problem will be documented in the ATS in accordance with the SBMS subject area, "Assessment Management" (PNNL 2008a). Corrective actions are documented in ATS in accordance with the SBMS subject area, "Assessment Management" (PNNL 2008a).

If a deficiency is found where a procedure or process is not followed or the activity is not in compliance with a procedure or process, the deficiency will be documented into the ATS in accordance with the SBMS subject area, "Assessment Management" (PNNL 2008a). Corrective action will be documented using ATS in accordance with the SBMS subject area, "Assessment Management" (PNNL 2008a) and as discussed in Sections 8.0 and 11.0.

Subcontractors will be required to have a system to identify and disposition nonconforming items, procedure deficiencies, processes not followed, or activities not in compliance to a procedure or a process. This requirement will be specified in a SOW. 


\subsection{Document Control}

\subsection{Project Quality Assurance Plan Control}

Distribution and control of this QAPjP shall be performed in accordance with SBMS subject area, "Scientific and Technical Information" (PNNL 2007a). Modifications to this plan shall be made either by revision or by issuing an Interim Change Notice (ICN). See Figure 19.1 for the ICN form and instructions. This plan will be revised after four ICNs or a major change in project scope or requirements. Any PNNL staff member may request a change to this QAPjP by submitting the requested change in writing to the Project Manager and Quality Engineer. All reviewers listed on the signature page and affected by the change will approve the revision. The ICN will be placed in front of the signature page and the individual pages will be inserted, or the necessary correction will be lined out and the correction added with the appropriate approval initials and date. The QAPjP will be reviewed at least annually unless a different review cycle is documented.

\subsection{Technical Procedure Control}

Technical procedures referenced by this QAPjP and used by PNNL staff will be contained in a PNNL internal procedure manual, as appropriate. Technical procedures will be distributed and controlled in accordance with the SBMS subject area, "Document Control" (PNNL 2006b). Modifications to any of the internal procedures shall be made either by revision or by issuance of an ICN.

Procedures will be revised after two major ICNs, or if the procedure format has changed. Any PNNL staff member may request a change to procedures at any time by submitting the requested change in writing to the author. The author, technical reviewer, Task Manager, and project Quality Engineer will review and approve the ICN. The Project Manager may delegate his/her review and approval authority. The ICN will be placed in front of the signature page and the individual pages will be inserted, or the necessary correction will be lined out and the correction added with the appropriate approval initials and date. Contact the project Quality Engineer for the electronic copy of the ICN. New or revised technical procedures, whether they will be included in the internal procedures manual or not, must be developed in accordance with SBMS subject area, "Procedures, Permits, and Other Work Instructions" (PNNL 2004). The procedure owner is required to review the procedure at least every 2 years.

\subsection{Administrative Procedure/Instruction Preparation and Control}

Administrative procedures/instructions used by PNNL staff will be developed, approved, and controlled to ensure consistent application by those staff performing the defined task(s). These procedures/instructions will be developed, approved, and controlled in a manner that has been approved by the appropriate Project Manager and Quality Engineer. 


\section{INSTRUCTIONS FOR ICN FORM}

HEADER:

The ICN number is identified as ICN No.-

For a published document, each page of the ICN shall have a header on the right upper corner that includes the report number, the date and the pagination. The number of the ICN must be placed after the PNNL number. The second line of the header should show the date and pagination. The cover sheet needs to identify how many pages in the ICN packet.

Example header: PNNL-xxxxx-ICN-x

Month, day, year; Page $\mathrm{x}$ of $\mathrm{xx}$

\section{SECTION A.}

Self-explanatory.

\section{SECTION B.}

Include all actions that the document holder must take to update the procedure or instruction. Possible actions include: replacing pages of the document with pages that are distributed with the ICN and marking up the document (in ink) to reflect the changes identified on the ICN or attach the ICN cover sheet to the front of the document.

For a "Published" groundwater monitoring plan include the following statement: "Attach this ICN to the front of the document, just before the title page."

\section{SECTION C.}

Identify, by title, all personnel whose job functions will be affected by the change and include a brief description of the effect. If there is no effect on personnel (e.g., the change was made to clarify the intent of the procedure or to correct a typographical error) this block should be marked "N/A."

\section{SECTION D.}

State the reason for the change followed by a description of the change (including the affected paragraph, information which is deleted, and the actual wording of any replacement test) for each change included on the ICN.

\section{SECTION E.}

The Cognizant Manager shall document the reason for not obtaining original reviewers approval and/or any other decisions that must be documented. Additionally, list the individuals who will receive the document (distribution list).

\section{SECTION F.}

Identify type of change and document required approvals.

Figure 19.1. Interim Change Notice 


\section{INTERIM CHANGE NOTICE}

(ICN)

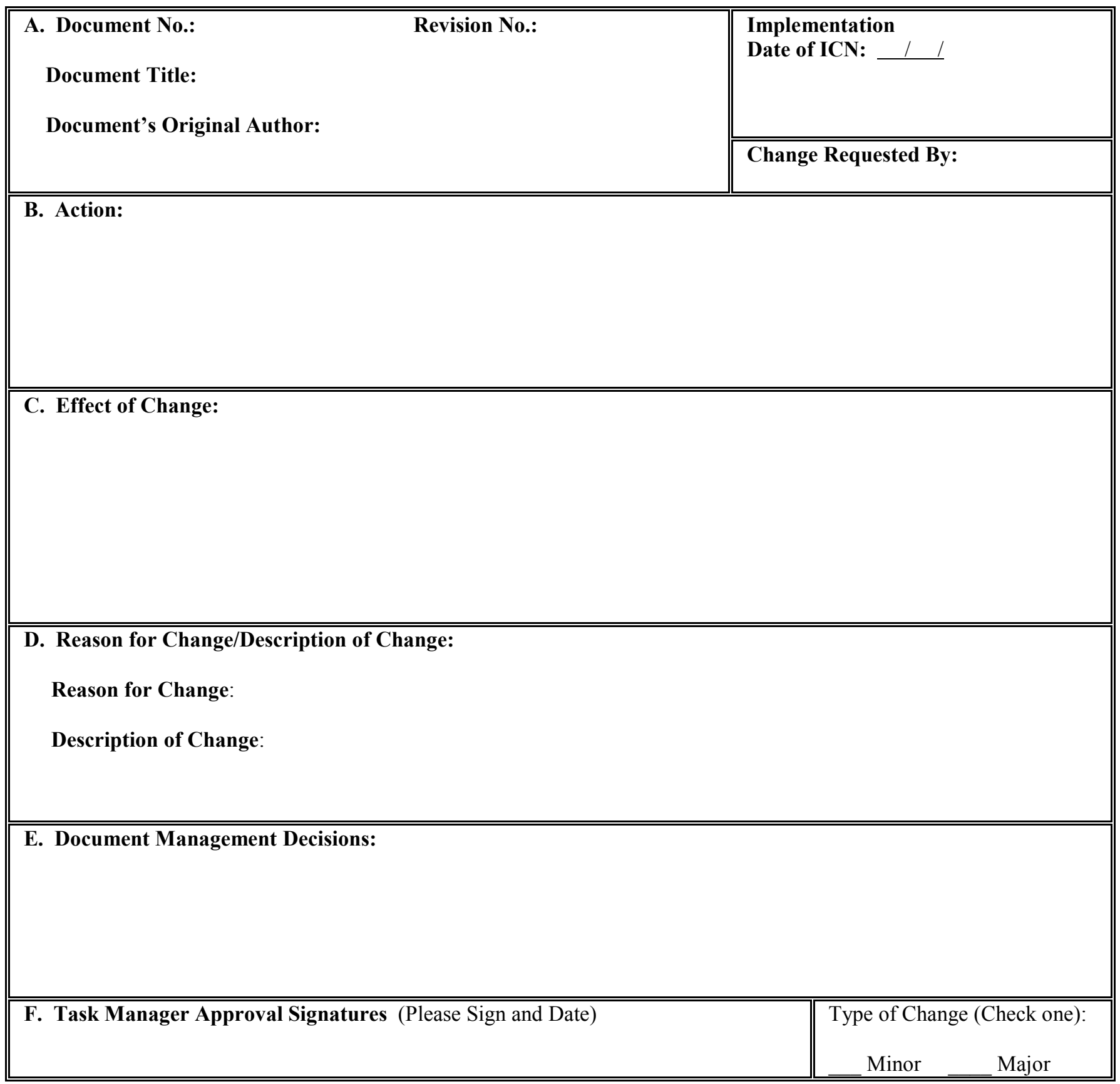

Project Quality Engineer Approval:

Date:

Author Approval:

Date:

Other Approvals: Date:

Figure 19.1. (contd) 


\subsection{Test Plans and Other Work Documents}

Test plans and other work instructions used by PNNL staff will be developed, approved, and controlled to ensure consistent application by those staff performing the defined task(s). These procedures/instructions will be developed, approved, and controlled in a manner that has been approved by appropriate the Project Manager or delegate and Quality Engineer. Distribution and control of test plans and other plans shall be performed in accordance with the SBMS subject area, "Publishing Scientific and Technical Information" (PNNL 2007a).

\subsection{Field Notebooks and Laboratory Record Books}

Field notebooks and LRBs used by PNNL 300 Area IFRC Project staff will be managed, controlled, and reviewed in accordance with the SBMS subject area, "Laboratory Record Books" (PNNL 2000). In particular, the Project Manager shall ensure that all field notebooks and LRBs are reviewed at least twice yearly. The reviewer, a qualified individual, confirms that there is sufficient detail to trace the investigation and confirm the test results or repeat the investigation and achieve comparable results, without recourse to the original investigator.

Non-PNNL 300 Area IFRC Project staff, such as subcontractors and/or collaborators, shall comply with the following procedural steps regarding LRBs, or a 300 Area IFRC Project-approved equivalent:

1. Use bound books similar to the LRBs with beige-colored binding used by PNNL.

2. The initial LRB custodian shall complete the title, author, and period covered sections of the information block (first sheet inside the cover). If the LRB is transferred, the new custodian shall enter their name, payroll number, location, and date received to the lower portion of the information block.

3. If persons other than the custodian make entries, the custodian shall list above or below the information block on the first sheet inside the LRB cover, the names of those persons and obtain sample signature and initials from each.

4. Use the following procedure as new project number and project or activities are initiated.

- Record the starting page, the project or activity title in the table of contents.

- Record as the first entry the research activity title, the project or work authorization number, and a brief description of the objectives and planned approach.

- Record observations/data chronologically. Describe (narrative or sketch) experimental apparatus, equipment, and any procedures, data sheets, etc., that are used.

5. Date and sign each page. List person(s) who performed the work.

6. Record information only in permanent ink, line out unused portions of pages, and keep pages intact.

7. Do not erase or obliterate entries. Mark out errors or corrections with single lines. Initial and date all changes other than editorial corrections. If the change is substantive, record the reason for it.

8. Use the following steps if it is necessary to attach a loose sheet.

- Attach the sheet to an unused page of the LRB by tape or glue. 
- Write the LRB and page numbers on the attached sheet (in case it comes loose).

- Make an entry in the LRB to introduce or describe the attached sheet.

9. Maintain a list in the project or activity file identifying the LRB numbers, custodians, and locations.

10. Record as the last entry for a project or activity a statement noting completion of the work or, if appropriate, reference to a subsequent LRB.

11. Store LRBs in metal file cabinets or receptacles that prevent physical damage or access by unauthorized persons when not in use, and allow easy retrieval for periodic inventory.

12. Notify the 300 Area IFRC Project Document Control in writing when LRBs are reassigned.

13. Return LRBs to the 300 Area IFRC Project Document Control or Project Manager when complete or at project end. Users may copy appropriate pages for their personal files and future reference. If the staff member for future reference retains the LRBs, they must be protected from physical damage or access by unauthorized persons and made available for periodic inventory.

14. Return LRBs to 300 Area IFRC Project Document Control or request reassignment when the custodian terminates employment.

15. Make copies of LRBs, or applicable pages, for inclusion in project files, when appropriate.

\subsection{References}

10 CFR Part 830, Subpart A, “Quality Assurance Requirements.” Code of Federal Regulations.

CAWSRP - Conducting Analytical Work in Support of Regulatory Programs. 2008. Pacific Northwest National Laboratory.

CERCLA - Comprehensive Environmental Response, Compensation, and Liability Act. 1980. Public Law 96-150, as amended, 94 Stat. 2767, 42 USC 9601 et seq.

DOE Order 414.1C. 2005. “Quality Assurance.” U.S. Department of Energy, Washington, D.C.

DOE Order 435.1. 2001. "Radioactive Waste Management." U.S. Department of Energy, Washington, D.C.

DOE Order 450.1. 2003, (as amended). “Environmental Protection Program.” U.S. Department of Energy, Washington, D.C.

DOE Order 5400.5. 1993 (as amended). "Radiation Protection of the Public and the Environment." U.S. Department of Energy, Washington, D.C.

DOE/RL-96-68. 2007. Hanford Analytical Services Quality Assurance Requirements Documents. HASQARD, Volumes 1, 2, 3, and 4. U.S. Department of Energy, Richland Operations Office, Richland, Washington.

Ecology - Washington State Department of Ecology, U.S. Environmental Protection Agency, and U.S. Department of Energy. 1989 (as amended). Hanford Federal Facility Agreement and Consent Order. Document No. 89-10 (The Tri-Party Agreement), Olympia, Washington. 
EMSL-LV-0539-17. 1979. Radiochemical Analytical Procedures for Analysis of Environmental Samples. U.S. Environmental Protection Agency, Las Vegas, Nevada.

EPA/240/B-01/003. 2001. EPA Requirements for Quality Assurance Project Plans (QA/R-5).

U.S. Environmental Protection Agency, Washington, D.C.

EPA/240/B-06/001. 2006. Guidance on Systematic Planning Using the Data Quality Objectives Process $(Q A / G-4)$. U.S. Environmental Protection Agency, Washington, D.C.

EPA-600/4-79/019. 1979. Handbook for Analytical Quality Control in Water and Wastewater Laboratories. U.S. Environmental Protection Agency, Cincinnati, Ohio.

EPA-600/4-79-020. 1983. Methods for Chemical Analysis of Water and Wastes. U.S. Environmental Protection Agency, Washington, D.C.

EPA-600/4-80-032. 1980. Prescribed Procedures for Measurement of Radioactivity in Drinking Water. U.S. Environmental Protection Agency, Cincinnati, Ohio.

EPA-R4-73-014. 1973. Procedures for Radiochemical Analysis of Nuclear Reactor Aqueous Solutions. U.S. Environmental Protection Agency, Cincinnati, Ohio.

EPA/SW-846. 1986 (as amended). Test Methods for Evaluating Solid Waste: Physical/Chemical Methods, SW-846, Third Edition. Office of Solid Waste and Emergency Response, U.S. Environmental Protection Agency, Washington, D.C. Available online at http://www.epa.gov/epaoswer/hazwaste/test/main.htm

Johnson TC, FD Day-Lewis, K Singha, CD Johnson, RJ Versteeg, and JW Lane Jr. 2008. Best Practices for Crosshole Electrical Resistivity Tomography. U.S. Geological Survey, Storrs, Connecticut (in process).

Lichtner PC. 2001. FLOTRAN: User's Manual. LA-UR-02-2349. Los Alamos National Laboratory, Los Alamos, New Mexico.

National Water Well Association. 1986. RCRA Ground Water Monitoring Technical Enforcement Guidance Document. Dublin, Ohio.

NQA-1-2000. 2001. Quality Assurance Requirements for Nuclear Facility Applications. The American Society of Mechanical Engineers, New York.

PAAA-Price-Anderson Amendments Act. Energy Policy Act of 2005. Title VI-Nuclear Matters, Subtitle A-Price-Anderson Act Amendments, Section 601 et. seq. Public Law 109-58, as amended. 42 USC 15801 et seq.

PNL-MA-567. 1993, as amended. Procedures for Ground-Water Investigations. Pacific Northwest National Laboratory, Richland, Washington.

PNNL. 2000. Laboratory Record Books. Standards-Based Management System, Pacific Northwest National Laboratory, Richland, Washington.

PNNL. 2002. Training Design, Development, Implementation and Evaluation. Standards-Based Management System, Pacific Northwest National Laboratory, Richland, Washington. 
PNNL. 2004. Procedures, Permits, and Other Work Instructions. Standards-Based Management System, Pacific Northwest National Laboratory, Richland, Washington.

PNNL. 2005. Calibration. Standards-Based Management System, Pacific Northwest National Laboratory, Richland, Washington.

PNNL. 2006a. Battelle Policies and Standards. Standards-Based Management System, Pacific Northwest National Laboratory, Richland, Washington

PNNL. 2006b. Document Control. Standards-Based Management System, Pacific Northwest National Laboratory, Richland, Washington.

PNNL. 2006c. Suspect/Counterfeit Items and Misrepresented Products, Reporting and Handling. Pacific Northwest National Laboratory, Richland, Washington.

PNNL. 2007a. Publishing Scientific and Technical Information. Standards-Based Management System, Pacific Northwest National Laboratory, Richland, Washington.

PNNL. 2007b. Software. Standards-Based Management System, Pacific Northwest National Laboratory, Richland, Washington.

PNNL. 2008a. Assessment Management. Standards-Based Management System, Pacific Northwest National Laboratory, Richland, Washington.

PNNL. 2008b Procurement. Standards-Based Management System, Pacific Northwest National Laboratory, Richland, Washington.

PNNL. 2008c. Purchase Orders/Subcontracts. Standards-Based Management System, Pacific Northwest National Laboratory, Richland, Washington.

PNNL. 2008d. Purchasing Cards (P-Cards). Standards-Based Management System, Pacific Northwest National Laboratory, Richland, Washington.

PNNL. 2008e. Purchasing Through the Business-to-Business Program. Standards-Based Management System, Pacific Northwest National Laboratory, Richland, Washington.

PNNL. 2008f. Records Management. Standards-Based Management System, Pacific Northwest National Laboratory, Richland, Washington.

PNNL. 2008g. Reporting Noncompliances with DOE Requirements for Nuclear Safety and Worker Safety and Health. Standards-Based Management System, Pacific Northwest National Laboratory, Richland, Washington.

PNNL. 2008h. Safety Software. Standards-Based Management System, Pacific Northwest National Laboratory, Richland, Washington.

PNNL. 2008i. Sample Handling, Archival, and Disposal. Standards-Based Management System, Pacific Northwest National Laboratory, Richland, Washington.

PNNL. 2008j. Waste, Managing. Standards-Based Management System, Pacific Northwest National Laboratory, Richland, Washington. 
PNNL. 2009a. Electrical Equipment: Designing, Purchasing, and Installing, Standards-Based Management System, Pacific Northwest National Laboratory, Richland, Washington.

PNNL 2009b. Hazardous Materials, Packaging and Shipping. Standards-Based Management System, Pacific Northwest National Laboratory, Richland, Washington.

PNNL. 2009c. Training and Qualification for Staff and Non-Staff. Standards-Based Management System, Pacific Northwest National Laboratory, Richland, Washington.

Prommer H, DA Barry, and C Zheng. 2003. "A MODFLOW/MT3DMS Based Multicomponent Reactive Transport Model." Ground Water 41(2): 247-257.

Ptak T, M Piepenbrink, and E Martac. 2004. "Tracer Tests for the Investigation of Heterogeneous Porous Media and Stochastic Modeling of Flow And Transport - a Review of Some Recent Developments." J. Hydrol. 294: 122-163.

Ptak T and G Teutsch. 1994. "Forced and Natural Gradient Tracer Tests in a Highly Heterogeneous Porous Aquifer: Instrumentation and Measurements." J. Hydrol. 159: 79-104.

QAP ESL. Environmental Sciences Laboratory QA Plan, current revision. Pacific Northwest National Laboratory, Richland, Washington.

RCRA - Resource Conservation and Recovery Act. 1976. Public Law 94-580, as amended, 90 Stat. 2795, 42 USC 6901 et seq.

Rew RK and GP Davis. 1990. "NetCDF: An Interface for Scientific Data Access.” IEEE Computer Graphics and Applications 10(4):76-82.

U.S. Geological Survey (USGS). 1977. National Handbook of Recommended Methods for Water Data Acquisition. Office of Water Data Coordination, Reston, Virginia.

Versteeg R, A Richardson, and T Rowe. 2006. "Web Accessible Scientific Workflow System for Performance Monitoring." Environ. Sci. Technol.: 10.1021/es0517421 S0013-936X(05)01742-6.

WAC 173-160. "Minimum Standards for Construction and Maintenance of Wells." Washington Administrative Code, Olympia, Washington.

Yeh T, CJ Liu, and SY Liu. 2000. "Hydraulic Tomography: Development of a New Aquifer Test Method." Water Resour. Res. 36: 2095-2105. 
Appendix A

300 Area IFRC Project Quality Control Plan 



\section{Appendix A}

\section{Area IFRC Project Quality Control Plan}

\section{A.1 Introduction}

This appendix describes the basic methods and procedures to implement a quality control (QC) task for sampling and analysis conducted in association with the 300 Area IFRC Project. The QC practices described in this plan help to evaluate whether samples free of contamination are obtained during sampling and that the laboratory performed sample analyses within the accuracy and precision limits required by the project.

Most of the information in this appendix applies only to groundwater samples. QC practices and requirements that pertain to soil and sediment samples are described in Section A.5.

The primary objectives of this plan are listed below:

1. Identify the QC elements selected for the 300 Area IFRC Project.

2. Provide data quality objectives (DQO) for reporting limits, precision, accuracy, and completeness.

3. Indicate actions that are to be taken for out-of-tolerance data.

\section{A.2 Technical Requirements}

The technical requirements for QC are divided into two types-components that provide checks on field and laboratory activities (Field QC) and factors that help to monitor laboratory performance (Laboratory QC). Each type of QC sample has required frequencies and acceptance criteria.

The following guidance documents were used as aids in determining the QC elements necessary for the Groundwater Performance Assessment Project:

1. Quality Assurance Manual for the Waste Management Branch Investigations (EPA 910/9-86-00).

2. Resource Conservation and Recovery Act (RCRA) Groundwater Monitoring Technical Enforcement Guidance Document (EPA/OSWER-9950.1).

3. Test Methods for Evaluating Solid Waste: Physical/Chemical Methods, SW-846, Third Edition (EPA/SW-846).

4. Handbook for Analytical Quality Control in Water and Wastewater Laboratories (EPA-600/4-79-019).

5. Hanford Analytical Services Quality Assurance Requirements Documents (HASQARD) (DOE/RL-96-68).

QC elements were selected based on the needs of the project and value that results from each type of sample will add to the database. 


\section{A.2.1 Field Quality Control}

To indicate whether samples are collected in a consistent manner and are properly preserved, three types of QC samples will be collected before or during sampling:

1. Sampling Event Blanks - These samples will be prepared by the sampling team before traveling to a sampling site. A preserved bottle set, identical to the set that will be used for sample collection in the field, will be filled with reagent water (carbon free, de-ionized water). Dead water from well 699-S11-E12AP is used for low-level tritium. The bottles will be sealed by the sampling team and transported unopened to the field in the same storage container that will be used for the samples collected that day. These samples will be typically analyzed for the same constituents as the samples from the associated well.

2. Equipment Blanks - Reagent water will be passed through the pump or manifold after decontamination (sometimes just prior to sampling) to collect blank samples identical to a set that will be collected in the field. Preserved bottles will be used. The equipment blank bottles will be placed in the same container as the associated field samples and not removed from the container until delivery to the laboratory.

3. Field Duplicates - A replicate sample that is collected at one well. After each type of bottle is filled, a second, identical bottle will be filled for each type of analysis as directed by chain-of-custody requirements. Both sets of samples will be stored and transported together.

Using several types of field blank samples provides checks on bottle cleanliness, preservative purity, equipment decontamination, proper storage and transport of samples, and reveals whether or not samples may have been contaminated during collection. Sampling in replicate provides information about sampling reproducibility. Field QC sample frequencies are shown in Table A.1. In addition to the evaluation characteristics described in Table A.1, the field QC samples also provide a check on the analytical results. The field QC data are designed to give an overall impression of the performance of the sampling and analysis of the 300 Area IFRC Project; however, individual data points associated with field QC samples that are outside of the acceptance criteria are flagged in the database.

The results of each type of field QC sample are evaluated according to criteria defined in Table A.2.

Bias will be assessed by comparing a measured value to a known or accepted reference value or the recovery of a known amount of spiked contaminant into a sample (i.e., a matrix spike [MS]). An MS bias caused by matrix effects will be calculated as follows in Equation (A.1):

$$
\mathrm{B}=\left(\mathrm{X}_{\mathrm{s}}-\mathrm{X}_{\mathrm{u}}\right)-\mathrm{K}
$$

where $\quad X_{\mathrm{s}}=$ measured value of spiked sample

$\mathrm{X}_{\mathrm{u}}=$ sample or miscellaneous contribution

$\mathrm{K}=$ known value of spike

Using the following Equation (A.2) yields percent recovery (\%R):

$$
\% \mathrm{R}=100\left(\mathrm{X}_{\mathrm{s}}-\mathrm{X}_{\mathrm{u}}\right) / \mathrm{K}
$$


Table A.1. Quality Control Samples

\begin{tabular}{|c|c|c|}
\hline \multicolumn{3}{|c|}{ Field QC } \\
\hline Sample Type & Primary Characteristics Evaluated & Frequency \\
\hline Sample Event Blank & Contamination from containers or transportation & 1 per 20 wells sampled \\
\hline Equipment Blank & Contamination from non-dedicated equipment & As needed ${ }^{(a)}$ \\
\hline Replicate/Duplicate Samples & Reproducibility & 1 per 20 wells sampled \\
\hline \multicolumn{3}{|c|}{ Laboratory QC } \\
\hline Sample Type & Primary Characteristics Evaluated & Frequency \\
\hline Method Blanks & Laboratory Contamination & 1 per batch \\
\hline Lab Duplicates & Laboratory Reproducibility & (b) \\
\hline Matrix Spikes & Matrix Effect and Laboratory Accuracy & (b) \\
\hline Matrix Spike Duplicates & Laboratory Reproducibility/Accuracy & (b) \\
\hline Surrogates & Recovery/Yield & (b) \\
\hline Laboratory Control Samples & Method Accuracy & 1 per batch \\
\hline \multicolumn{3}{|c|}{$\begin{array}{l}\text { (a) For portable Grundfos pumps, equipment blanks are collected one per ten wel } \\
\text { non-dedicated equipment is used, an equipment blank shall be collected every } \\
\text { be shown that less frequent collection of equipment blanks is adequate to mor } \\
\text { procedure for the non-dedicated equipment. } \\
\text { (b) As defined in the laboratory contract or QA plan and/or analysis procedures. } \\
\text { QA = Quality assurance. } \\
\text { QC = Quality control. }\end{array}$} \\
\hline
\end{tabular}

Table A.2. Field and Laboratory QC Elements and Acceptance Criteria

\begin{tabular}{|c|c|c|c|}
\hline Method & QC Element & Acceptance Criteria & Corrective Action \\
\hline \multicolumn{4}{|c|}{ General Chemical Parameters } \\
\hline \multirow{7}{*}{$\begin{array}{l}\text { Alkalinity - EPA } 600 \text { Series, } 310.1 \\
\text { Chemical Oxygen Demand - EPA } 600 \text { Series, } 410.4 \\
\text { Conductivity - EPA } 600 \text { Series, } 120.1 \\
\text { Oil and Grease - EPA } 600 \text { Series, } 413.1 \\
\text { pH - EPA } 600 \text { Series, } 150.1 \\
\text { Total Dissolved Solids - EPA } 600 \text { Series, } 160.1 \\
\text { Total Organic Carbon - SW-846, } 9060 \\
\text { Total Organic Halides - SW-846, } 9020 \\
\end{array}$} & $\mathrm{MB}^{(\mathrm{a})}$ & $<\mathrm{MDL}$ & Flagged with "C" \\
\hline & LCS & $80-120 \%$ recovery $^{(b)}$ & Data reviewed $^{(\mathrm{c})}$ \\
\hline & DUP & $\pm 20 \% \mathrm{RPD}^{(\mathrm{b})}$ & Data reviewed $^{(\mathrm{c})}$ \\
\hline & $\mathrm{MS}^{(\mathrm{d})}$ & $75-125 \%$ recovery $^{(b)}$ & Flagged with "N" \\
\hline & EB, FTB & $<2 \mathrm{X}$ MDL & Flagged with "Q" \\
\hline & Field Duplicate & $\pm 20 \% \mathrm{RPD}^{(\mathrm{e})}$ & Flagged with "Q" \\
\hline & & & \\
\hline \multicolumn{4}{|c|}{ Ammonia and Anions } \\
\hline \multirow{6}{*}{$\begin{array}{l}\text { Ammonia - EPA } 600 \text { Series, } 350.1 \\
\text { Anions by IC - EPA } 600 \text { Series, } 300.0 \\
\text { Cyanide - SW-846, } 9012\end{array}$} & MB & $<\mathrm{MDL}$ & Flagged with "C" \\
\hline & LCS & $80-120 \%$ recovery $^{(b)}$ & Data reviewed $^{(\mathrm{c})}$ \\
\hline & DUP & $\pm 20 \% \mathrm{RPD}^{(\mathrm{b})}$ & Data reviewed $^{(\mathrm{c})}$ \\
\hline & MS & $75-125 \%$ recovery $^{(\text {b) }}$ & Flagged with "N" \\
\hline & EB, FTB & $<2 \mathrm{X}$ MDL & Flagged with "Q" \\
\hline & Field Duplicate & $\pm 20 \% \mathrm{RPD}^{(\mathrm{e})}$ & Flagged with "Q" \\
\hline \multicolumn{4}{|c|}{ Metals } \\
\hline \multirow{4}{*}{$\begin{array}{l}\text { Arsenic - SW-846, 7060 } \\
\text { Cadmium - SW-846, } 7131 \\
\text { Chromium - SW-846, } 7191 \\
\text { Lead - SW-846, 7421 }\end{array}$} & $\mathrm{MB}$ & $<\mathrm{CRDL}$ & Flagged with "C" \\
\hline & LCS & $80-120 \%$ recovery $^{(b)}$ & Data reviewed $^{(\mathrm{c})}$ \\
\hline & MS & $75-125 \%$ recovery $^{(b)}$ & Flagged with "N" \\
\hline & MSD & $\pm 20 \% \mathrm{RPD}^{(\mathrm{b})}$ & Data reviewed $^{(\mathrm{c})}$ \\
\hline
\end{tabular}


Table A.2. (contd)

\begin{tabular}{|c|c|c|c|c|c|}
\hline \multicolumn{3}{|c|}{$\begin{array}{r}\text { Method } \\
\end{array}$} & QC Element & Acceptance Criteria & Corrective Action \\
\hline \multirow{3}{*}{\multicolumn{3}{|c|}{$\begin{array}{l}\text { Mercury - SW-846, } 7470 \\
\text { Selenium - SW-846, } 7740 \\
\text { Thallium - SW-846, } 7841 \\
\text { ICP Metals - SW-846, 6010 } \\
\text { ICP/MS Metals - SW-846, } 6020\end{array}$}} & EB, FTB & $<2 \mathrm{X}$ MDL & Flagged with "Q" \\
\hline & & & Field Duplicate & $\pm 20 \% \mathrm{RPD}^{(\mathrm{e})}$ & Flagged with "Q" \\
\hline & & & & & \\
\hline \multicolumn{6}{|c|}{ Radiological Parameters } \\
\hline \multicolumn{3}{|c|}{ Gamma Scan } & MB & $<2 \mathrm{X}$ MDA & Flagged with "B" \\
\hline \multicolumn{3}{|c|}{ Gross Alpha - SW-846, 9310} & LCS & $70-130 \%$ recovery & Data reviewed $^{(\mathrm{c})}$ \\
\hline \multicolumn{3}{|c|}{ Gross Beta - SW-846, 9310} & DUP & $\pm 20 \% \mathrm{RPD}$ & Data reviewed $^{(\mathrm{c})}$ \\
\hline \multicolumn{3}{|c|}{ Iodine-129 } & $\mathrm{MS}^{(\mathrm{h})}$ & $60-140 \%$ recovery & Flagged with "N" \\
\hline \multicolumn{3}{|c|}{ Plutonium (isotopic) } & EB, FTB & $<2 \mathrm{X}$ MDA & Flagged with "Q" \\
\hline \multicolumn{3}{|c|}{ Strontium- $89 / 90$} & Field Duplicate & $\pm 20 \% \mathrm{RPD}^{(5)}$ & Flagged with “Q” \\
\hline \multicolumn{3}{|c|}{ Technetium-99 } & & & \\
\hline \multicolumn{3}{|c|}{ Tritium - SW-846, 906.0} & & & \\
\hline \multicolumn{3}{|c|}{ Tritium (low-level) } & & & \\
\hline \multicolumn{3}{|c|}{ Uranium (isotopic) } & & & \\
\hline \multicolumn{6}{|c|}{ 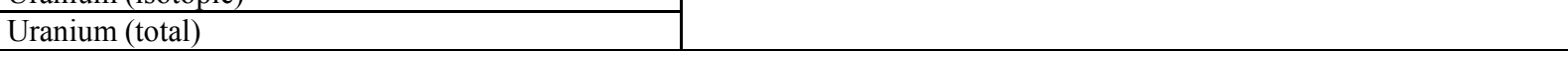 } \\
\hline \multirow{4}{*}{\multicolumn{6}{|c|}{$\begin{array}{l}\text { (a) Does not apply to } \mathrm{pH} \text {. } \\
\text { (b) Laboratory-determined, statistically derived control limits may also be used. Such limits are reported with the data. } \\
\text { (c) After review, corrective actions are determined on a case-by-case basis. Corrective actions may include a laboratory } \\
\text { recheck or flagging the data as suspect (Y flag) or rejected (R flag). }\end{array}$}} \\
\hline & & & & & \\
\hline & & & & & \\
\hline & & & & & \\
\hline \multicolumn{6}{|c|}{ (d) Applies to total organic carbon and total organic halides only. } \\
\hline \multicolumn{6}{|c|}{ (e) Applies only in cases where one or both results are greater than $5 \mathrm{X}$ the detection limit. } \\
\hline \multirow{2}{*}{\multicolumn{6}{|c|}{$\begin{array}{l}\text { (f) Determined by the laboratory based on historical data. Control limits are reported with the data. } \\
\text { (g) For common laboratory contaminants such as acetone, methylene chloride, 2-butanone, toluene, and phthalate esters, the } \\
\text { acceptance criteria is }<5 \mathrm{X} \text { MDL. }\end{array}$}} \\
\hline & & & & & \\
\hline \multicolumn{6}{|c|}{ (h) Applies only to technetium-99 and total uranium analyses. } \\
\hline \multicolumn{6}{|c|}{ Data Flags: } \\
\hline $\mathrm{B}, \mathrm{C}$ & $=$ & Possible laboratory contamina & lyte was detected i & he associated method bl & \\
\hline & $=$ & Result may be biased (associa & spike result was & side the acceptance lim & \\
\hline & $=$ & Problem with associated field & le (blank and/or d & icate results were out of & nits). \\
\hline DUP & & Laboratory matrix duplicate. & & & \\
\hline & & Equipment blank. & & & \\
\hline FTB & $=$ & Full trip blank. & & & \\
\hline FXR & $=$ & Field transfer blank. & & & \\
\hline & $=$ & Gas chromatography. & & & \\
\hline ICP & $=$ & Inductively coupled plasma. & & & \\
\hline $\mathrm{ICP} / \mathrm{MS}$ & $=$ & Inductively coupled plasma-m & rometry. & & \\
\hline LCS & $=$ & Laboratory control sample. & & & \\
\hline & $=$ & Method blank. & & & \\
\hline MDA & $=$ & Minimum detectable activity. & & & \\
\hline MDL & $=$ & Method detection limit. & & & \\
\hline MS & $=$ & Matrix spike. & & & \\
\hline MSD & $=$ & Matrix spike duplicate. & & & \\
\hline $\mathrm{PCBs}$ & $=$ & Polychlorinated biphenyls. & & & \\
\hline RPD & $=$ & Relative percent difference. & & & \\
\hline SUR & $=$ & Surrogate. & & & \\
\hline
\end{tabular}

Analytical precision will be determined by analyzing duplicates (field or lab). Precision is expressed as either percent relative standard deviation (RSD) or RPD. Duplicate results will be flagged if the results of both samples are quantifiable (i.e., the result is greater than the 5 times the instrument detection limit [IDL]/MDL/MDA) and the RPD is greater than 20\%. The RPD is calculated in Equation (A.3):

$$
R P D=\frac{D_{1}-D_{2}}{\left(D_{1}+D_{2}\right) / 2} \times 100
$$


where $\quad D_{1}=$ original sample value

$\mathrm{D}_{2}=$ duplicate sample value

When more than two data values are present, precision is calculated by the RSD (Equation [A.4]):

$$
\mathrm{RSD}=\frac{\text { standard deviation }}{\text { Mean }} \times 100
$$

\section{A.2.2 Quality Control in the Laboratory}

The ability to perform sample analyses within the limits established by the project will be monitored in several ways. This QAPjP governs laboratory work performed by staff participating in the 300 Area IFRC Project. The work activities in the laboratories will be periodically reviewed, including selected laboratories of subcontracted 300 Area IFRC Project collaborators The laboratory quality assurance effort includes a comprehensive QC program, which includes the use of matrix spikes, matrix duplicates, matrix spike duplicates, laboratory control samples, surrogates, tracers, and blanks. These samples are recommended in the guidance documents and are required by U.S. Environmental Protection Agency (EPA) protocol.

Matrix Duplicate - An intra-laboratory split sample used to evaluate the precision of a method in a given sample matrix.

Matrix Spike - An aliquot of a sample spiked with a known concentration of target analyte(s). The MS will be used to assess the bias of a method in a given sample matrix. Spiking will be done prior to sample preparation and analysis.

Matrix Spike Duplicate - A replicate spiked aliquot of a sample subjected to the entire sample preparation and analytical process. The results from these samples will be used to determine the bias and precision of a method in a given sample matrix.

Laboratory Control Sample - A control matrix spike (e.g., deionized water) spiked with analytes representative of the target analytes or a certified reference material used to evaluate laboratory accuracy.

Method Blank - An analyte-free matrix to which all reagents are added in the same volumes or proportions as used in sample processing. The method blank will be carried through the complete sample preparations and analytical procedure and used to quantify contamination resulting from the analytical process.

Tracers - A tracer is a known quantity of a chemical or radioactive isotope that is different from that of the isotope of interest but is expected to behave similarly and is added to an aliquot of sample. Sample results are generally corrected based on tracer recovery.

The samples are analyzed within the holding times specified by the analysis procedure. In some instances, constituents in samples not analyzed within the holding time may be compromised by volatilization, decomposition or other chemical changes. Data from samples analyzed outside the holding time are flagged in the 300 Area IFRC Project database with an $\mathrm{H}$. The holding times for constituents analyzed by the 300 Area IFRC Project are listed in Table A.3. Other tools are used by the project to evaluate analytical work. Double-blind standards of the constituents of concern will be used to evaluate 
laboratory performance. Because the results of double-blind standards provide information on laboratory precision and accuracy, these standards are useful tools to verify that the project DQOs are being met.

Table A.4 lists the typical blind-standard constituents. The list of constituents is subject to change based on need. Specific information about the constituents used and their spiking levels will be maintained in the project files.

Blind standards are prepared by spiking matrix groundwater and deionized water with known concentrations of constituents of interest. Spiking concentrations range from MDA or MDL, depending on the constituent measured, to the upper limit of concentration determined in groundwater on the Hanford Site. The matrix groundwater wells chosen are 699-49-100C for radiochemical analytes, and total organic halides (TOX); and 699-19-88 for cyanide, anions, inductively coupled plasma (ICP) metals, and total organic carbon (TOC). Deionized water is used to prepare VOCs. Well 699-49-100C is located to the west of the Hanford Site. Well 699-19-88 is a southern boundary well. Both wells are considered free of the contaminant migration zone. Dead water from well 699-S11-E12AP is used to prepare lowlevel tritium blind standards.

Table A.3. 300 Area IFRC Project Holding Times

\begin{tabular}{||l|l|l||}
\hline \multicolumn{1}{|c|}{ Constituents } & \multicolumn{1}{c|}{ Methods $^{\text {(a) }}$} & \multicolumn{1}{c||}{ Holding Times } \\
\hline \hline ICP metals & SW-846, 6010 & 6 months \\
\hline ICP-MS & SW-846, 6020 & 6 months \\
\hline Arsenic & SW-846, 7060 & 6 months \\
\hline Lead & SW-846, 7421 & 6 months \\
\hline Mercury & SW-846, 7470/7471 & 28 days \\
\hline Selenium & SW-846, 7740 & 6 months \\
\hline Thallium & SW-846, 7841 & 6 months \\
\hline Alkalinity & EPA 600 Series, 310.1 & 14 days \\
\hline Cyanide & SW-846, 9010/9012 & 14 days \\
\hline Bromide & EPA 600 Series, 300.0 & 28 days \\
\hline Chloride & EPA 600 Series, 300.0 & 28 days \\
\hline Fluoride & EPA 600 Series, 300.0 & 28 days \\
\hline Nitrate & EPA 600 Series, 300.0 & 48 hours \\
\hline Nitrite & EPA 600 Series, 300.0 & 48 hours \\
\hline Phosphate & EPA 600 Series, 300.0 & 48 hours \\
\hline Sulfate & EPA 600 Series, 300.0 & 28 days \\
\hline Total organic carbon & SW-846, 9060 & 28 days \\
\hline Total organic halides & SW-846, 9020 & 28 days \\
\hline Chemical oxygen demand & EPA 600 Series, 410.4 & 28 days \\
\hline (a) EPA/SW-846, as amended. & & \\
\hline \hline
\end{tabular}


Table A.4. Blind-Standard Constituents and Schedule

\begin{tabular}{|c|c|c|}
\hline Constituents & Recommended Recovery (\%) $)^{(\mathrm{a})}$ & Precision $(\% \mathrm{RSD})^{(\mathrm{a})}$ \\
\hline Fluoride & $\pm 25 \%$ & $\pm 25 \%$ \\
\hline Nitrate & $\pm 25 \%$ & $\pm 25 \%$ \\
\hline Cyanide & $\pm 25 \%$ & $\pm 25 \%$ \\
\hline Chromium & $\pm 20 \%$ & $\pm 20 \%$ \\
\hline Total organic carbon ${ }^{(b)}$ & Varies according to spiking compound & Varies according to spiking compound \\
\hline Total organic halides $^{(\mathrm{c})}$ & Varies according to spiking compound & Varies according to spiking compound \\
\hline Gross alpha $^{(\mathrm{d})}$ & $70-130 \%$ & $\pm 20 \%$ \\
\hline Gross beta $^{(\mathrm{e})}$ & $70-130 \%$ & $\pm 20 \%$ \\
\hline Tritium & $70-130 \%$ & $\pm 20 \%$ \\
\hline Tritium (low level) & $70-130 \%$ & $\pm 20 \%$ \\
\hline Cobalt-60 & $70-130 \%$ & $\pm 20 \%$ \\
\hline Strontium-90 & $70-130 \%$ & $\pm 20 \%$ \\
\hline Technetium-99 & $70-130 \%$ & $\pm 20 \%$ \\
\hline Iodine-129 & $70-130 \%$ & $\pm 20 \%$ \\
\hline Cesium-137 & $70-130 \%$ & $\pm 20 \%$ \\
\hline Uranium & $70-130 \%$ & $\pm 20 \%$ \\
\hline Plutonium-239/240 & $70-130 \%$ & $\pm 20 \%$ \\
\hline
\end{tabular}

Blind-standard results are evaluated by comparing the laboratory results to the actual spike values. Laboratory precision also is considered as the samples are sent to the laboratory in replicate. Laboratory results are evaluated based on the recovery and precision criteria listed in Table A.4. Results outside of these control limits are investigated and appropriate actions are taken, if necessary.

\section{A.3 Data Quality Objectives}

DQOs are defined for reporting limits, precision, accuracy, and completeness. Groundwater monitoring plans or sampling analysis plans specify whether or not a particular site has more stringent DQOs than those specified in this plan.

Limits for precision and accuracy for chemical analyses are based on criteria stipulated in the methods (e.g., EPA/SW-846, EPA 600 series). Precision and accuracy limits for radiochemical results are specified in the laboratory contract.

Completeness is defined as the percentage of data points judged to be valid. The percent complete each quarter should be at least $85 \%$.

Reporting limits for radiochemical constituents are defined in individual test plans. Reporting limits will be based on the research needs, but regulatory reporting limits and actual reporting limits are listed in Table A.5 for radiochemical constituents as a reference point. For chemical constituents, MDLs as low as one third the EPA drinking water standards are preferred. In some cases, MDLs that are one third the regulatory limit are not feasible (e.g., pentachlorophenol and cadmium). Because MDLs change frequently, these values are not provided in this document. 
Table A.5. Reporting Limits for Radiochemical Constituents

\begin{tabular}{|c|c|c|c|c|c|}
\hline $\begin{array}{c}\text { Constituent of } \\
\text { Concern }\end{array}$ & Method & CAS \# & DWS & $1 / 3 \mathrm{DWS}$ & $\mathrm{RDL}$ \\
\hline Gross Alpha & "Gross Alpha - GA & $12587-46-1$ & $15 \mathrm{pCi} / \mathrm{L}^{*}$ & $5 \mathrm{pCi} / \mathrm{L}^{*}$ & $3 \mathrm{pCi} / \mathrm{L}$ \\
\hline Gross Beta & Gross Beta - GB & $12587-47-2$ & $\mathrm{~N} / \mathrm{A}$ & $\mathrm{N} / \mathrm{A}$ & $4 \mathrm{pCi} / \mathrm{L}$ \\
\hline Cobalt-60 & Gamma Spec & $10198-40-0$ & $100 \mathrm{pCi} / \mathrm{L}$ & $33 \mathrm{pCi} / \mathrm{L}$ & $25 \mathrm{pCi} / \mathrm{L}$ \\
\hline Cesium-137 & & $10045-97-3$ & $200 \mathrm{pCi} / \mathrm{L}$ & $67 \mathrm{pCi} / \mathrm{L}$ & $15 \mathrm{pCi} / \mathrm{L}$ \\
\hline Europium-152 & & & & & $50 \mathrm{pCi} / \mathrm{L}$ \\
\hline Europium-154 & & & $200 \mathrm{pCi} / \mathrm{L}$ & $67 \mathrm{pCi} / \mathrm{L}$ & $50 \mathrm{pCi} / \mathrm{L}$ \\
\hline Europium-155 & & & $600 \mathrm{pCi} / \mathrm{L}$ & $200 \mathrm{pCi} / \mathrm{L}$ & $50 \mathrm{pCi} / \mathrm{L}$ \\
\hline Tritium & H-3 & $10028-17-8$ & $20,000 \mathrm{pCi} / \mathrm{L}$ & $6700 \mathrm{pCi} / \mathrm{L}$ & $400 \mathrm{pCi} / \mathrm{L}$ \\
\hline Tritium & H-3 (LL) & $\mathrm{N} / \mathrm{A}$ & $\mathrm{N} / \mathrm{A}$ & $\mathrm{N} / \mathrm{A}$ & $10 \mathrm{pCi} / \mathrm{L}$ \\
\hline Iodine-129 & I-129 & $10043-66-0$ & $1 \mathrm{pCi} / \mathrm{L}$ & $0.33 \mathrm{pCi} / \mathrm{L}$ & $5 \mathrm{pCi} / \mathrm{L}$ \\
\hline Iodine-129 & I-129 (LL) & $\mathrm{N} / \mathrm{A}$ & $\mathrm{N} / \mathrm{A}$ & $\mathrm{N} / \mathrm{A}$ & $1 \mathrm{pCi} / \mathrm{L}$ \\
\hline Strontium-90 & Sr-89/Sr-90 & $10098-97-2$ & $8 \mathrm{pCi} / \mathrm{L}$ & $2.7 \mathrm{pCi} / \mathrm{L}$ & $2 \mathrm{pCi} / \mathrm{L}$ \\
\hline Technetium-99 & Tc-99 & 14133-76-7 & $900 \mathrm{pCi} / \mathrm{L}$ & $300 \mathrm{pCi} / \mathrm{L}$ & $15 \mathrm{pCi} / \mathrm{L}$ \\
\hline Plutonium-238 & Isotopic Plutonium & & $1.6 \mathrm{pCi} / \mathrm{L}$ & $0.5 \mathrm{pCi} / \mathrm{L}$ & $1 \mathrm{pCi} / \mathrm{L}$ \\
\hline Plutonium-239/240 & Pu-AEA & & $1.2 \mathrm{pCi} / 1$ & $0.4 \mathrm{pCi} / \mathrm{L}$ & $1 \mathrm{pCi} / \mathrm{L}$ \\
\hline Uranium-233 & Isotopic Uranium & $13968-55-3$ & $20 \mathrm{pCi} / \mathrm{L}$ & $6.7 \mathrm{pCi} / \mathrm{L}$ & $1 \mathrm{pCi} / \mathrm{L}$ \\
\hline Uranium-234 & Isotopic Uranium & $13966-29-5$ & $20 \mathrm{pCi} / \mathrm{L}$ & $6.7 \mathrm{pCi} / \mathrm{L}$ & $1 \mathrm{pCi} / \mathrm{L}$ \\
\hline Uranium-235 & Uranium-AEA & $15117-96-1$ & $24 \mathrm{pCi} / \mathrm{L}$ & $8 \mathrm{pCi} / \mathrm{L}$ & $1 \mathrm{pCi} / \mathrm{L}$ \\
\hline Uranium-238 & & U-238 & $24 \mathrm{pCi} / \mathrm{L}$ & $8 \mathrm{pCi} / \mathrm{L}$ & $1 \mathrm{pCi} / \mathrm{L}$ \\
\hline $\begin{array}{l}\text { Total alpha energy } \\
\text { emitted from Radium }\end{array}$ & Total Radium & N/A & $\mathrm{N} / \mathrm{A}$ & $\mathrm{N} / \mathrm{A}$ & $1 \mathrm{pCi} / \mathrm{L}$ \\
\hline Uranium (elemental) & Total Uranium & N/A & $30 \mu \mathrm{g} / \mathrm{L}$ & $10 \mu \mathrm{g} / \mathrm{L}$ & $0.1 \mu \mathrm{g} / \mathrm{L}$ \\
\hline $\begin{array}{l}{ }^{*} \text { Excluding uranium } \\
\text { CAS\# }=\text { Chemical a } \\
\text { DWS }=\text { Drinking } \\
\text { N/A }=\text { Not applica } \\
\text { RDL }=\text { Required d }\end{array}$ & $\begin{array}{l}\text { stract service number } \\
\text { ter standard. } \\
\text { le. } \\
\text { tection limit. }\end{array}$ & & & & \\
\hline
\end{tabular}

\section{A.4 Reporting and Deliverables Requirements}

The results of the blind standards and the Field QC samples will be provided through current analytical reporting procedures. The QC analytical results will be reviewed and compiled in the 300 Area IFRC Project database.

All project records associated with QC are maintained in accordance with the File Plan Form for the 300 Area IFRC Project.

\section{A.5 Requirements for Soil and Sediment Samples}

The 300 Area IFRC Project will analyze sediment samples in support of site-characterization activities. The nature of this work precludes specification of many of the requirements listed previously for groundwater samples. Therefore, the types, quantities, and acceptance criteria for field and/or laboratory QC samples are specified in the characterization plan and specific test plans for individual experiments. Table A.6 lists the maximum recommended holding times for common analytes in soils. Radionuclides are not included in the table. 
Table A.6. Holding Times for Sediment Analyses

\begin{tabular}{||l|l|l||}
\hline \multicolumn{1}{|c|}{ Constituents } & \multicolumn{1}{c|}{ Methods $^{(\text {a) }}$} & \multicolumn{1}{c||}{ Holding Times } \\
\hline \hline ICP metals & SW-846, 6010 & 6 months \\
\hline ICP-MS & SW-846, 6020 & 6 months \\
\hline Arsenic & SW-846, 7060 & 6 months \\
\hline Lead & SW-846, 7421 & 6 months \\
\hline Mercury & SW-846, 7470/7471 & 28 days \\
\hline Selenium & SW-846, 7740 & 6 months \\
\hline Thallium & SW-846, 7841 & 6 months \\
\hline Alkalinity & EPA 600 Series, 310.1 & 14 days \\
\hline Cyanide & SW-846, 9010/9012 & 14 days \\
\hline Bromide & EPA 600 Series, 300.0 & 28 days \\
\hline Chloride & EPA 600 Series, 300.0 & 28 days \\
\hline Fluoride & EPA 600 Series, 300.0 & 28 days \\
\hline Nitrate & EPA 600 Series, 300.0 & 48 hours \\
\hline Nitrite & EPA 600 Series, 300.0 & 48 hours \\
\hline Phosphate & EPA 600 Series, 300.0 & 48 hours \\
\hline Sulfate & EPA 600 Series, 300.0 & 28 days \\
\hline Total organic carbon & SW-846, 9060 & 28 days \\
\hline Total organic halides & SW-846, 9020 & 28 days \\
\hline Chemical oxygen demand & EPA 600 Series, 410.4 & 28 days \\
\hline (a) EPA/SW-846, as amended. & \\
\hline & \multicolumn{2}{l}{} \\
\hline
\end{tabular}

\section{A.6 References}

DOE/RL-96-68. 1998. Hanford Analytical Services Quality Assurance Requirements Documents. (HASQARD), Volumes 1 through 4, U.S. Department of Energy, Richland, Washington.

EPA-600/4-79-019. 1979. Handbook for Analytical Quality Control in Water and Wastewater Laboratories. U.S. Environmental Protection Agency, Cincinnati, Ohio.

EPA 910/9-86-00. 1986. Quality Assurance Manual for Waste Management Branch Investigations. U.S. Environmental Protection Agency, Region 10, Seattle, Washington.

EPA/OWSER-9950.1. 1986. Resource Conservation and Recovery Act (RCRA) Groundwater Monitoring Technical Enforcement Guidance Document. U.S. Environmental Protection Agency, Washington, D.C.

EPA/SW-846. 1986 (as amended). Test Methods for Evaluating Solid Waste: Physical/Chemical Methods, SW-846, Third Edition. Office of Solid Waste and Emergency Response, U.S. Environmental Protection Agency, Washington, D.C. Available online at http://www.epa.gov/epaoswer/hazwaste/test/sw846.htm. 



\section{Appendix B}

\section{Experimental and Modeling Procedures for the 300 Area IFRC Project}





\section{Appendix B}

\section{Experimental and Modeling Procedures for the 300 Area IFRC Project}

\begin{tabular}{|c|c|c|c|}
\hline Method & Analysis & Document Number & Procedure Title \\
\hline $\begin{array}{l}\text { Conduct of Routine } \\
\text { Laboratory Operations }\end{array}$ & General & RPL-OP-001 & $\begin{array}{l}\text { Routine Research Operations } \\
\text { Section } 31 \text { tab } 3 \text { of RPL } \\
\text { Laboratory Handbook }\end{array}$ \\
\hline $\begin{array}{l}\text { Inductively Coupled } \\
\text { Plasma-Optical Emission } \\
\text { Spectroscopy (ICP-OES) }\end{array}$ & $\begin{array}{l}\mathrm{Ca}, \mathrm{K}, \mathrm{Mg}, \mathrm{P}, \mathrm{Sr}, \mathrm{Na}, \mathrm{Si} \\
\mathrm{Cu}, \mathrm{Fe}, \mathrm{Mn}, \mathrm{S} \text {, and } \mathrm{Ti} \text { in } \\
\text { water in ppb or moles/L }\end{array}$ & PNNL-AGG-ICP-AES ${ }^{\dagger}$ & $\begin{array}{l}\text { Inductively Coupled Plasma - } \\
\text { Optical Emission Spectrometry } \\
\text { (ICP-OES) Analysis }\end{array}$ \\
\hline $\begin{array}{l}\text { Inductively Coupled } \\
\text { Plasma-Mass Spectroscopy } \\
\text { (ICP-MS) }\end{array}$ & $\mathrm{Re}, \mathrm{Tc}$ & PNNL-AGG-415 & $\begin{array}{l}\text { Inductively Coupled Plasma } \\
\text { Mass Spectrometric (ICP-MS) } \\
\text { Analysis }\end{array}$ \\
\hline Ion Chromatography & $\begin{array}{l}\mathrm{F}, \mathrm{Cl}, \mathrm{NO}_{2}, \mathrm{NO}_{3}, \mathrm{CO}_{3}, \\
\mathrm{SO}_{4}, \mathrm{PO}_{4}, \mathrm{PO}_{4} \text { in water in } \\
\mathrm{ppm} \text { or moles/L }\end{array}$ & *PNNL-AGG-IC-001 & $\begin{array}{l}\text { Determinations by Ion } \\
\text { Chromatography (IC) }\end{array}$ \\
\hline $\mathrm{ICP} / \mathrm{MS}$ & $\begin{array}{l}\mathrm{Cu}, \mathrm{Fe} \text { in water in } \mathrm{ppb} \text { or } \\
\text { moles/L }\end{array}$ & $\begin{array}{l}\text { PNL-SAND-3.1 (needs to } \\
\text { be updated) }\end{array}$ & -- \\
\hline KPA & $\begin{array}{l}\mathrm{U} \text { in water in ppb or } \\
\mathrm{moles} / \mathrm{L}\end{array}$ & Liu et al. (2004) & -- \\
\hline Spectrophotometer & $\mathrm{Fe}(\mathrm{II})$ and total $\mathrm{Fe}$ in $\mathrm{ppb}$ & Kukkadapu et al. (2004) & -- \\
\hline LSC & $\begin{array}{l}\text { Sr90, Tc } 99, \text { I129, in } \\
\text { dpm } / \mathrm{mL}\end{array}$ & $\begin{array}{l}\text { *PNNL-AGG-RRL-002; } \\
\text { Procedures vary slightly for } \\
\text { different radioisotopes; } \\
\text { McKinley et al. (2006) for } \\
\text { Sr-90 }\end{array}$ & -- \\
\hline $\begin{array}{l}\text { Solid-State pH Electrode } \\
\text { and Meter }\end{array}$ & $\mathrm{pH}$, Bromide & AGG-PH-001 & $\mathrm{pH}$ Measurement \\
\hline X-ray Diffraction (XRD) & Mineralogy & RPL-XRD-PIP & $\begin{array}{l}\text { Operation of Scintag Pad-V } \\
\text { X-Ray Diffractor (RGD \#62) }\end{array}$ \\
\hline $\begin{array}{l}\text { Scanning Electron } \\
\text { Microscopy/ Energy- } \\
\text { Dispersive X-ray } \\
\text { Spectrometry (SEM/EDS) }\end{array}$ & $\begin{array}{l}\text { Particle morphology, size, } \\
\text { and qualitative elemental } \\
\text { analysis }\end{array}$ & PNL-SP-3 & $\begin{array}{l}\text { Scanning Electron } \\
\text { Microscopy/Energy Dispersive } \\
\text { Spectrometry }\end{array}$ \\
\hline Particle-Size Distribution & -- & PNL-MA-567, SA-3 & $\begin{array}{l}\text { Particle-size analysis (Pipette or } \\
\text { hydrometer method); Wet sieve } \\
\text { analysis will be used to remove } \\
\text { sand-size particle }\end{array}$ \\
\hline Hydraulic Conductivity & -- & PNL-MA-567, SA-5 & $\begin{array}{l}\text { Falling head hydraulic } \\
\text { conductivity }\end{array}$ \\
\hline Water Retention & -- & UFA-SK-01 & $\begin{array}{l}\text { Determination of water retention } \\
\text { as a function of water content } \\
\text { using open-flow centrifugation } \\
\text { techniques }\end{array}$ \\
\hline
\end{tabular}




\begin{tabular}{|c|c|c|c|}
\hline Method & Analysis & Document Number & Procedure Title \\
\hline Water Content & -- & PNL-MA-567, SA-7 & Water Content \\
\hline Bulk Density & -- & PNL-MA-567, SA-8 & Clod density/bulk density \\
\hline Particle Density & -- & PNL-MA-567, SA-9 & $\begin{array}{l}\text { Determining particle density; } \\
\text { necessary for constant head } \\
\text { hydraulic conductivity }\end{array}$ \\
\hline Column Packing & -- & $\begin{array}{l}\text { WHC-IP-0635, GEL-3 } \\
\text { Rev.3 }\end{array}$ & $\begin{array}{l}\text { Moisture relationships of soils; } \\
\text { necessary for constant head } \\
\text { hydraulic conductivity }\end{array}$ \\
\hline $\mathrm{pH} / \mathrm{EC}$ & -- & PNL-G-5-pH/EC & $\begin{array}{l}\text { Measuring } \mathrm{pH} / \mathrm{EC} \text { of low-level } \\
\text { radioactive solutions }\end{array}$ \\
\hline $\begin{array}{l}\text { Saturated column } \\
\text { experiments }\end{array}$ & -- & AGG-SAT-COL-001 & $\begin{array}{l}\text { Conducting saturated column } \\
\text { experiments }\end{array}$ \\
\hline Batch experiments & -- & AGG-BSE-001 & Batch sorption experiments \\
\hline Surface Area & -- & AGG-SA-001 & Measuring Surface area \\
\hline $\mathrm{TIC} / \mathrm{TOC}$ & $\begin{array}{l}\text { Inorganic } \mathrm{C} \text {, organic } \mathrm{C} \text {, } \\
\text { total } \mathrm{C}\end{array}$ & *PNNL-AGG-TOC-001 & -- \\
\hline X-ray Fluorescence & $\begin{array}{l}\text { Total analyses of sediments } \\
\text { including } \mathrm{Al}, \mathrm{Si}, \mathrm{K}, \mathrm{Ca} \text {, } \\
\mathrm{Mg}, \mathrm{Sr}, \mathrm{Ti}, \mathrm{Fe}, \mathrm{Mn}, \mathrm{Cu}, \mathrm{Ni} \text {, } \\
\mathrm{Cr}, \mathrm{Cs}, \mathrm{U} \text {, and others. }\end{array}$ & $\begin{array}{l}\text { *PNNL-AGG-OP-RGD74- } \\
001\end{array}$ & -- \\
\hline $\begin{array}{l}\text { Conventional Powder X-ray } \\
\text { Diffraction }\end{array}$ & $\begin{array}{l}\text { Mineral identity }(\% \\
\text { distribution })\end{array}$ & Qafoku et al. (2005) & -- \\
\hline Digital Autoradiography & $\begin{array}{l}\text { Identify locations of } \\
\text { radioactivity in sediment } \\
\text { thin section and mixtures } \\
\text { of sand and silt-sized } \\
\text { particles. }\end{array}$ & $\begin{array}{l}\text { Zeissler et al (2001), } \\
\text { McKinley et al. (2001) }\end{array}$ & -- \\
\hline $\begin{array}{l}\text { Scanning Electron } \\
\text { Microscopy } \\
\text { with WDS }\end{array}$ & $\begin{array}{l}\text { High resolution imaging of } \\
\text { particle morphology and } \\
\text { atomic mass generally in } \\
\text { sediment thin section; semi } \\
\text { quantitative imaging of } \\
\text { chemical distribution. }\end{array}$ & McKinley et al. (2005) & -- \\
\hline $\begin{array}{l}\text { Transmission Electron } \\
\text { Microscopy with Selected } \\
\text { Area Diffraction (SAED) }\end{array}$ & $\begin{array}{l}\text { Very high resolution of } \\
\text { single mineral grains in } \\
\text { cross section; local } \\
\text { morphology, structure and } \\
\text { atomic arrangement. }\end{array}$ & $\begin{array}{l}\text { Zachara et al. (2006). } \\
\text { Selected area diffraction } \\
\text { patterns are interpreted } \\
\text { using the JADE software } \\
\text { (see below) using x-ray } \\
\text { powder diffraction data } \\
\text { (PDF) retrieved from a } \\
\text { standards library (ICDD, } \\
\text { 2003) }\end{array}$ & -- \\
\hline Electron microprobe & $\begin{array}{l}\text { Quantitative, intermediate } \\
\text { sensitivity chemical } \\
\text { mapping in thin sections. } \\
\text { Chemical transects across } \\
\text { grain/particle boundaries. }\end{array}$ & $\begin{array}{l}\text { Wang et al. (2005), Catalano } \\
\text { et al. (2006) }\end{array}$ & -- \\
\hline
\end{tabular}




\begin{tabular}{|c|c|c|c|}
\hline Method & Analysis & Document Number & Procedure Title \\
\hline $\begin{array}{l}\text { X-ray fluorescence } \\
\text { microprobe }\end{array}$ & $\begin{array}{l}\text { High sensitivity, semi } \\
\text { quantitative mapping of } \\
\text { element distributions in } \\
\text { sediment thin sections at } \\
\text { scales of } 10 \mu \mathrm{m} \text {. }\end{array}$ & $\begin{array}{l}\text { Liu et al. (2004), } \\
\text { Fredrickson et al. (2004) }\end{array}$ & -- \\
\hline $\begin{array}{l}\text { X-ray absorption } \\
\text { spectroscopy }\end{array}$ & $\begin{array}{l}\text { Determination of element } \\
\text { coordination structure, } \\
\text { nearest neighbors, and } \\
\text { bond distances in } \\
\text { contaminated sediment. }\end{array}$ & $\begin{array}{l}\text { Catalano et al. (2004); } \\
\text { Catalano et al. (2006). } \\
\text { Basic experimental } \\
\text { synchrotron measurements } \\
\text { are modeled with FEFF, } \\
\text { FEFFIT, and IFEFFIT (see } \\
\text { below) to extract molecular } \\
\text { information. }\end{array}$ & -- \\
\hline Synchrotron diffraction & $\begin{array}{l}\text { Identification of mineral } \\
\text { structures } \\
\text { In sediment thin sections. }\end{array}$ & $\begin{array}{l}\text { Catalano et al. (2004). } \\
\text { Mineral structures are } \\
\text { derived by application of the } \\
\text { FIT2D software (see below). }\end{array}$ & -- \\
\hline $\begin{array}{l}\text { Cryogenic laser induced } \\
\text { fluorescence spectroscopy } \\
\text { (CLIFS) }\end{array}$ & $\begin{array}{l}\text { Vibronic spectra of U(VI) } \\
\text { in water and solids to } \\
\text { establish molecular and } \\
\text { mineralogic environment. }\end{array}$ & $\begin{array}{l}\text { Wang et al. (2004) (for } \\
\text { aqueous solutions) and } \\
\text { Wang et al. (2008)(for } \\
\text { solids). Data analysis is } \\
\text { performed using the IGOR } \\
\text { and Globals programs (see } \\
\text { below). }\end{array}$ & -- \\
\hline $\begin{array}{l}\text { Batch kinetic desorption } \\
\text { experiments }\end{array}$ & $\begin{array}{l}\text { Sediments are bathed in } \\
\text { electrolyte of known } \\
\text { composition and the time- } \\
\text { variant release of } \\
\text { contaminants and other } \\
\text { solid associated ions are } \\
\text { monitored by aqueous } \\
\text { phase analyses. }\end{array}$ & $\begin{array}{l}\text { Procedures vary as per } \\
\text { element and its } \\
\text { concentration. Examples } \\
\text { include Liu et al. (2003) } \\
\text { (Cs-137), Liu et al. (2004) } \\
\text { (U), McKinley et al. (2005) } \\
\text { (Sr-90). Kinetic rate laws } \\
\text { and rate constants are } \\
\text { calculated from the data } \\
\text { using microscopic, diffusion } \\
\text { based transport models (See } \\
\text { below). Steady-state values } \\
\text { can be used to establish } \\
\text { thermodynamic parameters, } \\
\text { such as the solubility } \\
\text { product of a precipitated } \\
\text { contaminant phase (e.g., } \\
\text { Ilton et al. (2006). }\end{array}$ & -- \\
\hline
\end{tabular}




\begin{tabular}{|c|c|c|c|}
\hline Method & Analysis & Document Number & Procedure Title \\
\hline $\begin{array}{l}\text { Batch adsorption } \\
\text { experiments }\end{array}$ & $\begin{array}{l}\text { Sediments are bathed in } \\
\text { electrolyte of know } \\
\text { composition that has been } \\
\text { spiked with a contaminant } \\
\text { of interest. The adsorption } \\
\text { of the contaminant is } \\
\text { monitored as a function of } \\
\text { pH, ionic strength, or ion } \\
\text { composition. }\end{array}$ & $\begin{array}{l}\text { Example procedures are } \\
\text { equilibrium -Turner et al. } \\
\text { (1996) (U) and Zachara et } \\
\text { al. (2002) (Cs); kinetic - Liu } \\
\text { et al. (2003) (Cs), Liu et al. } \\
\text { (2004) (U), and McKinley et } \\
\text { al. (2006) (Sr). } \\
\text { Experimental results are } \\
\text { fitted with various } \\
\text { geochemical models } \\
\text { (MINTEQ; Geochemists } \\
\text { Workbench; GMIN; or } \\
\text { FITEQL see below) to } \\
\text { identify suites of adsorption } \\
\text { reactions (ion exchange or } \\
\text { surface complexation). }\end{array}$ & -- \\
\hline Column experiments & $\begin{array}{l}\text { Sediment }(<2 \mathrm{~mm} \text { or }<4 \\
\text { mm) is packed into a } \\
\text { cylindrical plastic, glass, or } \\
\text { stainless steel column. } \\
\text { Electrolyte with or without } \\
\text { a contaminant tracer is } \\
\text { applied to the column to } \\
\text { study the release (from } \\
\text { contaminated sediment) or } \\
\text { sorption/retardation (for } \\
\text { uncontaminated sediments) } \\
\text { of key contaminants of } \\
\text { concern. }\end{array}$ & $\begin{array}{l}\text { Qafoku et al. (2005). The } \\
\text { basic experimental data that } \\
\text { is in the form of chemical } \\
\text { concentration as a function } \\
\text { of leaching volume of fluid, } \\
\text { must be modeled with } \\
\text { various commercial and } \\
\text { research codes to yield } \\
\text { useable information. } \\
\text { CXTFIT is used to fit } \\
\text { physical transport } \\
\text { parameters such as the } \\
\text { dispersivity, while other } \\
\text { models are linked with a } \\
\text { solver of the advective- } \\
\text { dispersion equation to } \\
\text { describe 1-dimensional } \\
\text { reactive transport. The } \\
\text { reactive transport models } \\
\text { include a commercial one } \\
\text { (the Geochemists } \\
\text { Workbench) and others } \\
\text { assembled by the research } \\
\text { team including the } \\
\text { Distributed Rate Model } \\
\text { (DRM) and the Dual } \\
\text { Continuum Model (DCM). } \\
\text { These are described below. }\end{array}$ & -- \\
\hline MINTEQA2 Version 4 & $\begin{array}{l}\text { Commercial software used } \\
\text { to calculate aqueous } \\
\text { speciation, } \\
\text { precipitation/dissolution, } \\
\text { and adsorption/desorption } \\
\text { equilibria for low to } \\
\text { intermediate-strength } \\
\text { solutions. }\end{array}$ & $\begin{array}{l}\text { Code published by Allison } \\
\text { et al. (1991, 1998) linked to } \\
\text { a thermodynamic database } \\
\text { of our own synthesis (see } \\
\text { below). }\end{array}$ & -- \\
\hline Geochemists Workbench & $\begin{array}{l}\text { Commercial software to } \\
\text { calculate geochemical } \\
\text { equilibria, reaction network } \\
\text { modeling, and reactive } \\
\text { transport. }\end{array}$ & $\begin{array}{l}\text { Geochemists Workbench } \\
\text { Release } 6 . \text { from Craig } \\
\text { Bethke, Hydrogeology } \\
\text { Program, University of } \\
\text { Illinois }\end{array}$ & -- \\
\hline
\end{tabular}




\begin{tabular}{|c|c|c|c|}
\hline Method & Analysis & Document Number & Procedure Title \\
\hline CXTFIT & $\begin{array}{l}\text { Commercial software for } \\
\text { fitting column effluent } \\
\text { data. }\end{array}$ & Toride et al. (1999) & -- \\
\hline FITEQL (V 4.0) & $\begin{array}{l}\text { Commercial software used } \\
\text { to calculate equilibrium } \\
\text { constants and their } \\
\text { statistics for aqueous, } \\
\text { surface and precipitated } \\
\text { phases from batch } \\
\text { experimental data. }\end{array}$ & Herbelin and Westall (1999) & -- \\
\hline GMIN & $\begin{array}{l}\text { An equilibrium } \\
\text { geochemical model used to } \\
\text { calculate aqueous } \\
\text { speciation, precipitation/ } \\
\text { dissolution, and adsorption } \\
\text { desorption equilibria for } \\
\text { high ionic strength } \\
\text { solutions. Maintained by } \\
\text { PNNL. }\end{array}$ & Felmy (1995) & -- \\
\hline Spectral Fitting Software & $\begin{array}{l}\text { Commercial software used } \\
\text { to fit fluorescence emission } \\
\text { spectra on U(VI) derived } \\
\text { from CLIFS analyses. The } \\
\text { fitting allows } \\
\text { determination of the } \\
\text { precise spectral } \\
\text { wavelengths and } \\
\text { deconvolutes spectral } \\
\text { signatures resulting from } \\
\text { multiple fundamental } \\
\text { species. }\end{array}$ & Beechem et al. (1991) & -- \\
\hline $\begin{array}{l}\text { Phase Identification for } \\
\text { Powder Diffraction } \\
\text { (JADE+, V 5) }\end{array}$ & $\begin{array}{l}\text { Commercial software used } \\
\text { to manipulate powder } \\
\text { diffraction files are for } \\
\text { comparison with reference } \\
\text { spectra in for mineral } \\
\text { identification. }\end{array}$ & $\begin{array}{l}\text { Materials Data Inc., } \\
\text { Livermore, CA; ICDD, } \\
2003\end{array}$ & -- \\
\hline $\begin{array}{l}\text { Reactive Transport } \\
\text { Modeling }\end{array}$ & $\begin{array}{l}\text { The Dual Continuum } \\
\text { Model (DCM) is used to } \\
\text { model the reactive } \\
\text { transport of contaminants } \\
\text { 1-dimensional laboratory } \\
\text { columns and in } \\
\text { multidimensional field } \\
\text { simulations. The model is } \\
\text { a reaction-based simulator } \\
\text { and requires significant } \\
\text { parameterization using } \\
\text { batch and column data, and } \\
\text { physical measurements of } \\
\text { sediment characteristics. } \\
\text { Maintained by LANL. }\end{array}$ & Lichtner et al. $(2000,2001)$ & -- \\
\hline
\end{tabular}




\begin{tabular}{|c|c|c|c|}
\hline Method & Analysis & Document Number & Procedure Title \\
\hline Empirical Kinetic Modeling & $\begin{array}{l}\text { The distributed rate model } \\
\text { (DRM) is used to } \\
\text { empirically describe } \\
\text { complex kinetic } \\
\text { desorption/dissolution } \\
\text { phenomena in sediment } \\
\text { that is controlled by } \\
\text { chemical kinetics or diffuse } \\
\text { mass transport. The basic } \\
\text { model describes kinetic } \\
\text { phenomena using a } \\
\text { statistical distribution of } \\
\text { first order rate constants. } \\
\text { Maintained at PNNL. }\end{array}$ & Culver et al. (1997) & -- \\
\hline $\begin{array}{l}\text { Surface Complexation } \\
\text { Model }\end{array}$ & $\begin{array}{l}\text { The surface complexation } \\
\text { model (SCM) is used to } \\
\text { describe the surface } \\
\text { chemical reactions of } \\
\text { U(VI) that are responsible } \\
\text { for its adsorption to vadose } \\
\text { zone and aquifer } \\
\text { sediments. Maintained by } \\
\text { USGS. }\end{array}$ & Davis et al. (2004) & -- \\
\hline Thermodynamic Data Base & $\begin{array}{l}\text { A large thermodynamic } \\
\text { data base is maintained and } \\
\text { constantly updated based } \\
\text { on literature advances. The } \\
\text { data base describes } \\
\text { stability constants for } \\
\text { aqueous complexes and } \\
\text { solubility products for } \\
\text { precipitated phases } \\
\text { relevant to S\&T research } \\
\text { and issues. This data base } \\
\text { is used in almost every } \\
\text { S\&T geochemical study. } \\
\text { There are many hundreds } \\
\text { of entries in the data base } \\
\text { for a variety of } \\
\text { contaminants that is used } \\
\text { in MINTEQA@; } \\
\text { Geochemists Workbench, } \\
\text { and all of the reactive } \\
\text { transport codes. } \\
\text { Maintained at PNNL. }\end{array}$ & $\begin{array}{l}\text { The data base relies on the } \\
\text { following and many other } \\
\text { sources: Grenthe et al. } \\
\text { (1992) (U), Guillaumount et } \\
\text { al. (2003) (U), and Rard } \\
\text { (1999) (Tc) }\end{array}$ & -- \\
\hline $\begin{array}{l}\text { Saturated Hydraulic } \\
\text { Conductivity }\end{array}$ & -- & Wietsma et al. (2009) & $\begin{array}{l}\text { Saturated hydraulic conductivity } \\
\text { using constant flux, constant } \\
\text { head, and falling head methods. }\end{array}$ \\
\hline Multistep retention & -- & Tuli et al. (2001) & $\begin{array}{l}\text { Determination of water } \\
\text { saturation as a function of } \\
\text { capillary pressure by imposing a } \\
\text { series of increasing air pressures } \\
\text { on cores. }\end{array}$ \\
\hline $\begin{array}{l}\text { The document number st } \\
\text { and refer to the same ana }\end{array}$ & $\begin{array}{l}\text { s ICP-AES, but the instrume } \\
\text { ical technique. }\end{array}$ & in use is an ICP-OES. ICP- & and ICP-OES are equivalent \\
\hline
\end{tabular}

*PNNL-AGG referenced procedures are from PNNL's Applied Geochemistry Group 


\section{B.1 References}

Allison JD, DS Brown, and KJ Novo-Gradac. 1998. MINTEQA2/PRODEFA2, A Geochemical Assessment Model for Environmental Systems: User Manual Supplement for Version 4.0. U.S. Environmental Protection Agency, Washington, D.C.

Allison JD, DS Brown, and KJ Novo-Gradac. 1991. MINTEQA2/PRODEFA2, A Geochemical Assessment Model for Environmental Systems: Version 3.0 User's Manual. U.S. Environmental Protection Agency, Washington, D.C.

Beechem JM, E Gratton, and WW Mantulin. 1991. Globals Unlimited. University of Illinois at UrbanaChampaign Publication, Urbana-Champaign, Illinois.

Catalano JG, JP McKinley, JM Zachara, SC Smith, and GE Brown, Jr. 2006. "Changes in Uranium Speciation Through a Depth Sequence of Contaminated Hanford Sediments." Environ. Sci. Technol. 40(8), 2517-2524.

Catalano JG, SM Heald, JM Zachara, and GE Brown, Jr. 2004. "Spectroscopic and Diffraction Study of Uranium Speciation in Contaminated Vadose Zone Sediments from the Hanford Site, Washington State." Environ. Sci. Technol. 38:2822-2828.

Culver TB, SP Hallisey, D Sahoo, JJ Deitsch, and JA Smith. 1997. "Modeling the Desorption of Organic Contaminants from Long-Term Contaminated Soil Using Distributed Mass Transfer Rates." Environ. Sci. Technol. 31:1581-1588.

Davis JA, DE Meece, M Kohler, and GP Curtis. 2004. "Approaches to Surface Complexation Modeling of Uranium(VI) Adsorption on Aquifer Sediments." Geochim. Cosmochim. Acta 68:3621-3641.

Felmy AR. 1995. "GMIN. A Computerized Chemical Equilibrium Program Using a Constrained Minimization of the Gibbs Free Energy: Summary Report." In Chemical Equilibrium and Reaction Models (eds. RH Loeppert, AP Schwab, and S Goldberg) pp. 377-407, Soil Science Society of America.

Fredrickson JK, JM Zachara, DW Kennedy, RK Kukkadapu, JP McKinley, SM Heald, C Liu, and AE Plymale. 2004. "Reduction of $\mathrm{TcO}^{4-}$ by Sediment-Associated Biogenic Fe(II)." Geochim. Cosmochim. Acta 68(15):3171-3187.

Grenthe I, J Fuger, RJM Konings, RJ Lemire, AB Muller, C Nguyen-Trung, and H Wanner. 1992. Chemical Thermodynamics of Uranium. North-Holland, Amsterdam.

Guillaumount R, T Fanghanet, V Neck, J Fuger, DA Palmer, I Grenthe, and MH Rand. 2003. Update on the Chemical Thermodynamics of Uranium, Neptunium, Plutonium, Americium, and Technetium. Elsevier.

Hammersley AP. 1997. FIT2D: An Introduction and Overview. Internal Report ESRF97HA02T; European Synchrotron Radiation Facility, Grenoble, France.

Herbelin A and J Westall. 1999. FITEQL: A Computer Program for Determination of Chemical Equilibrium Constants from Experimental Data, Version 4.0. Report 99-01. Oregon State University, Corvallis, Oregon. 
International Centre for Diffraction Data (ICDD). 2003. JCPDS Powder Diffraction Files, PDF. ICDD, Newtown, Square, Pennsylvania.

Ilton ES, C Liu, W Yantasee, Z Wang, D Moore, and JM Zachara. 2005. "The Effect of Carbonate on the Dissolution of Synthetic Na-Boltwoodite." Geochimica et Cosmochimica Acta 70(19):4836-4849.

Kukkadapu RK, JM Zachara, JK Fredrickson, and DW Kennedy. 2004. "Biotransformation of Two-Line Silica-Ferrihydrite by a Dissimilatory Fe(III)-Reducing Bacterium: Formation of Carbonate Green Rust in the Presence of Phosphate." Geochim. Cosmochim. Acta 68(13):2799-2814.

Lichtner PC. 2001. FLOTRAN: User's Manual. Report No. LA-UR-02-2349, Los Alamos National Laboratory, Los Alamos, New Mexico.

Lichtner PC. 2000. "Critique of Dual Continuum Formulations of Multicomponent Reactive Transport in Fractured Porous Media, Dynamics of Fluids in Fractured Rock." Geophys. Monograph 122:281-298.

Liu C, JM Zachara, W Yantasee, PD Majors, and JP McKinley. 2006. "Microscopic Reactive Diffusion of Uranium in the Contaminated Sediments at Hanford, USA: Characterization and Modeling." Water Resources Research, Vol. 42, W12420, doi:10.1029/2006WR005031.

Liu C, JM Zachara, O Qafoku, JP McKinley, SM Heald, and Z Wang. 2004. "Dissolution of Uranyl Microprecipitates in Subsurface Sediments at Hanford Site, USA." Geochim. Cosmochim. Acta 68(22):4519-4537.

Liu C, JM Zachara, SC Smith, JP McKinley, and CC Ainsworth. 2003. "Desorption Kinetics of Radiocesium from Subsurface Sediments at Hanford Site, USA." Geochim. Cosmochim. Acta 67(16):2893-2912.

McKinley JP, JM Zachara, SC Smith, and C Liu. 2007. “Cation Exchange Reactions Controlling Desorption of ${ }^{90} \mathrm{Sr}^{2+}$ from Coarse-Grained Contaminated Sediments from the Hanford Formation, Washington." Geochimica et Cosmochimica Acta 71(2):305-325.

McKinley JP, JM Zachara, C Liu, and SC Heald. 2006. "Precipitation of Waste Uranium as a Uranyl Silicate in Microfractures." Geochimica et Cosmochimica Acta 70(8):1873-1887.

McKinley JP, RJ Serne, JM Zachara, CJ Zeissler, and RM Lindstrom. 2001. "The Distribution and Retention of ${ }^{137} \mathrm{Cs}$ in Sediments at the Hanford Site, Washington." Environ. Sci. Technol. 35:3433-3441.

Newville M. 2001a. "IFEFFIT: Interactive XAFS Analysis and FEFF Fitting.” J. Synch. Rad. $8: 322-324$.

Newville M. 2001b. “EXAFS Analysis Using FEFF and FEFFIT.” J. Synch. Rad. 8:96-100.

Qafoku NP, JM Zachara, C Liu, PL Gassman, OS Qafoku, and SC Smith. 2005. "Kinetic Desorption and Sorption of U(VI) During Reactive Transport in a Contaminated Hanford Sediment." Environ. Sci. Technol. 39:3157-3165.

Rard JA, MH Rand, G Anderegg, and H Wanner. 1991. Chemical Thermodynamics of Technetium, Chapter 3; (MCA Sandino and E Osthols, eds.), Elsevier, The Netherlands, Amsterdam, pp. 544. 
Toride N, FJ Leij, and MT van Genuchten. 1999. The CXTFIT Code for Estimating Transport Parameters from Laboratory or Field Tracer Experiments. U.S. Salinity Laboratory, Riverside, California.

Tuli A, MA Denton, JW Hopmans, T Harter, and JLMacIntyre. 2001. Multi-step Outflow Experiment: From Soil Preparation to Parameter Estimation. Department of Land, Air, and Water Paper. No 100037. University of California, Davis, California.

Turner GD, JM Zachara, JP McKinley, and SC Smith. 1996. "Surface-Charge Properties and $\mathrm{UO}_{2}{ }^{2+}$ Adsorption of a Subsurface Smectite." Geochim. Cosmochim. Acta 60:3399-3414.

Wang Z, JM Zachara, PL Gassman, O Qafoku, and J Catalano. 2008. "Fluorescence Spectroscopy of U(VI)-Silicates and U(VI)-Contaminated Hanford Sediment." Geochim. Cosmochim. Acta 69(6):1391-1403.

Wang Z, JM Zachara, JP McKinley, SC Smith, and SM Heald. 2005. "Cryogenic Laser Induced U(VI) Fluorescence Studies of a U(VI) Substituted Natural Calcite: Implications to U(VI) Speciation in Contaminated Hanford Sediments.” Environ. Sci. Technol. 39:2651-2659.

Wang Z, JM Zachara, W Yantasee, PL Gassman, C Liu, and AG Joly. 2004. “Cryogenic Laser Induced Fluorescence Characterization of U(VI) in Hanford Vadose Zone Pore Waters." Environ. Sci. Technol. 38(21):5591-5597.

Webb SM. 2005. "SIXPack: A Graphical User Interface for XAS Analysis Using IFEFFIT." Phys. Scr. T115, 1011-1014.

Wietsma, TW, M Oostrom, MA Covert, TW Queen, and MJ Fayer. 2009. “An Automated Apparatus for Constant Flux, Constant Head, and Falling Head Hydraulic Conductivity Measurements." Soil Science Society of America J. (In Press).

Zachara JM, SC Smith, C Liu, JP McKinley, RJ Serne, and PL Gassman. 2002. "Sorption of Cs+ to Micaceous Subsurface Sediments from the Hanford Site, USA.” Geochim. Cosmochim. Acta 66:193-211.

Zeissler CJ, RM Lindstrom, and JP McKinley. 2001. "Radioactive Particle Analysis by Digital Autoradiography." J. Radioanal. Nuclear Chem. 248(2):407-412. 



\section{Distribution}

No. of

Copies

ONSITE

4 Pacific Northwest National Laboratory

S. Y. Enloe

K8-96

N. J. Fix

M. D. Freshley

J. M. Zachara
No. of

$\underline{\text { Copies }}$

\section{OFFSITE}

All 300 Area IFRC Project Participants (to be accessible as a PDF on the project website).

Distr.1 


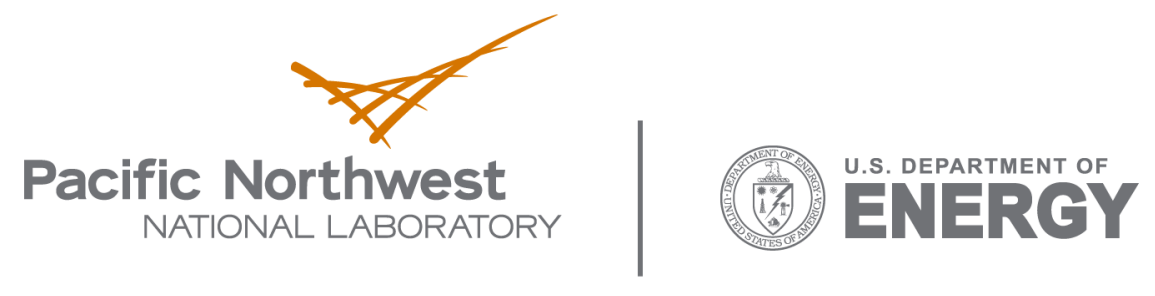

902 Battelle Boulevard

P.O. Box 999

Richland, WA 99352

1-888-375-PNNL (7665)

www.pnl.gov 